UNIVERSIDADE DE SÃO PAULO

FACULDADE DE FILOSOFIA LETRAS E CIÊNCIAS HUMANAS

DEPARTAMENTO DE GEOGRAFIA

PROGRAMA DE PÓS-GRADUAÇÃO EM GEOGRAFIA FÍSICA

LARISSA FERNANDA VIEIRA MARTINS

\title{
MONITORAMENTO DE PARQUES URBANOS EM FUNDOS DE VALE: ANÁLISE DAS FUNÇÕES DE CONSERVAÇÃO E USO PÚBLICO - ESTUDOS DE CASSOS MÚLTIPLOS EM CURITIBA, PARANÁ
}

Versão Corrigida 


\section{MONITORAMENTO DE PARQUES URBANOS EM FUNDOS DE VALE: ANÁLISE DAS FUNÇÕES DE CONSERVAÇÃO E USO PÚBLICO - ESTUDOS DE CASSOS MÚLTIPLOS EM CURITIBA, PARANÁ}

Tese apresentada ao Programa de Pós Graduação em Geografia Física da Universidade de São Paulo para obtenção do título de Doutora em Ciências (Geografia Física).

Área de Concentração: Paisagem e Planejamento Ambiental.

Orientador: Prof. Dr. Luis Antonio Bittar Venturi

Versão Corrigida 
MARTINS, Larissa Fernanda Vieira. Monitoramento de Parques Urbanos em fundos de vale: análise das funções de conservação e uso público - estudos de casos múltiplos em Curitiba, Paraná. Tese apresentada ao Programa de Pós-Graduação em Geografia Física da Universidade de São Paulo para obtenção do título de Doutora em Ciências (Geografia Física).

Aprovada em:

Banca examinadora

Prof. Dr.

Intituição:

Julgamento: Assinatura:

Prof. Dr. Intituição:

Julgamento: Assinatura:

Prof. Dr. Intituição:

Julgamento: Assinatura:

Prof. Dr. Intituição:

Julgamento: Assinatura: 


\section{AGRADECIMENTOS}

Ao professor Doutor Luis Antonio Bittar Venturi pela oportunidade, atenção e orientação.

À Coordenação de Aperfeiçoamento de Pessoal de Nível Superior (CAPES) pela concessão de bolsa de Doutorado.

Meus sinceros agradecimentos. 


\section{RESUMO}

MARTINS, L. F. V. Monitoramento de Parques Urbanos em fundos de vale: análise das funções de conservação e uso público - estudos de casos múltiplos em Curitiba, Paraná. 2014. Tese (Doutorado) - Faculdade de Filosofia Letras e Ciências Humanas, Universidade de São Paulo, São Paulo, 2014.

Os Parques Urbanos caracterizam-se como a principal área livre para o lazer e recreação da população e da manutenção dos sistemas naturais no ambiente citadino. Para que estes espaços possam cumprir com suas funções, a administração pública deve manejar de forma equitativa os aspectos naturais e de recreação e lazer. O principal objetivo desta pesquisa foi demonstrar a potencial ineficiência da conciliação entre as funções de Uso Público e Conservação em parques urbanos de tipologia ecológica, localizados em fundos de vale. Adotou-se como hipótese que, a equidade não ocorra devido à concepção paisagística, a qual favorece o uso público, ao instalar equipamentos e infraestruturas destinadas à população, em áreas originalmente frágeis, permitindo que a conservação torne-se um aspecto secundário. Para tanto, desenvolveu-se um sistema de monitoramento por meio de indicadores qualificados e mensurados por escores, os quais visaram identificar elementos que possam subsidiar o cumprimento das funções supracitadas; segregou-se os indicadores em duas categorias: $i$ ) Uso Público (7 indicadores) e ii) Conservação (7 indicadores); para determinar a existência de conciliação, os indicadores foram sintetizados em dois índices numéricos (Índice de Conservação (IC) e Índice de Uso Público (IUP), escalonados entre 0 e 10) e posteriormente cruzados em uma matriz de interação, a qual permite inferir 5 classes de conciliação: $i)$ Alta Equidade, ii) Boa Equidade, iii) Moderada Equidade, iv) Baixa Equidade, e v) Inexistente. Com o intuito de assegurar a replicabilidade, o sistema foi aplicado em 3 (três) parques na cidade de Curitiba (PR), com diferentes características de formação e concepção paisagística. A primeira unidade de análise, o Parque Municipal Nascentes do Belém, apresentou o melhor IC $(9,6)$ e o menor IUP $(2,8)$, atribuindo a área o cumprimento da função de conservação e o baixo cumprimento da função de uso público, permitindo que não ocorra conciliação, classificando-o como "Baixa Equidade"; o Parque Municipal Cajuru, obteve um IC de 4,7 pontos e um IUP de 5,1, fator que indica que as funções sejam cumpridas moderadamente e que ocorra conciliação entre elas; o Parque Municipal Passaúna, apresentou o melhor IC e IUP, respectivamente, 8,2 e 7,3 pontos, apresentando condições de conciliação entre as funções. De acordo com os resultados obtidos, a hipótese inicial foi refutada, principalmente frente ao estudo conduzido no Parque Municipal Nascentes do Belém, onde se verificou maior atenção para a manutenção dos aspectos naturais e a insuficiência de elementos para fins de uso público, ocorrendo exatamente o inverso das conjecturas levantadas; os estudos conduzidos nos Parques Cajuru e Passaúna, também corroboram os resultados. O sistema de monitoramento mostrou-se eficiente ao seu propósito, em apontar se o parque cumpre com as funções e se ocorre conciliação, segundo critérios pré-estabelecidos, além de apontar eventuais falhas na gestão e nortear áreas prioritárias ao manejo.

Palavras-chave: Parque Urbano. Indicadores Ambientais. Escores. Fundo de Vale. 


\begin{abstract}
MARTINS, L. F. V. Monitoring Urban Parks in River Corridors: analysis of the functions of conservation and public use - multiple case studies in Curitiba, Paraná. 2014. Tese (Doutorado) - Faculdade de Filosofia Letras e Ciências Humanas, Universidade de São Paulo, São Paulo, 2014.
\end{abstract}

The Urban Parks are characterized as the main free area for leisure and recreation of population and the main form of upkeep of natural systems environmental urban. In order that those spaces can perform with their function the public administration should manage from form equitable the aspects naturals and recreation and lounge. The main objective this research was to evidence the potential inefficiency of conciliation between the functions of Public Use and Conservation in urban parks of ecological typology, located in river corridors. Was adopted as hypothesis that, equity don't happen due to landscape conception, what favor the public, use to install equipment and infrastructure intended to population in originally fragile areas, allowing the conservation become as secondary aspect. For this, developed a system of monitoring through qualified indicators and measured by scores, which aimed at identifying elements who can subsidize performance of the duties cited, segregating the indicators in two categories: i) Public Use (7 indicators) and ii) Conservation (7 indicators); for set the existence of conciliation, the indicators were synthesized in two numerical indices (Conservation Indice (CI) and Public Use Indice (PUI), staggered between 0 and 10) and subsequently crossed in a interaction matrix, which allows interfere 5 grade of conciliation: $i$ ) High Equity, ii ) Good Equity, iii)Moderate Equity, iv) Low Equity and v) Nonexistent Equity. With the aim to ensuring the replicability, the system was applied in 3 (three) parks in Curitiba (PR), with different characteristics of formation and landscape conception. The first analysis unit, the Municipal Park Nascentes do Belém show the best CI $(9,6)$ and the PUI lowest $(2,8)$ assigning area of compliance function of conservation and the low assigning of function of public use, allowing not occur reconciliation, classifying as "Low Equity"; the Municipal Park Cajuru, obtain a CI of 4,7 points and a PUI of 5,1, factor that indicates that functions are fulfilled moderately and that reconciliation occurs between them; the Municipal Park Passúna, submitted the best CI and PUI, respectively, 8,2 and 7,3 points, presenting conditions of equilibrium between the functions. According with the result obtained, the initial hypothesis are refuted, principally because of the study on Municipal Park Nascentes do Belem, which was found large attention for upkeep of natural aspects and the failure of elements for purposes of public use, occurring exactly the opposite of the conjecture raised; Studies conducted in the Park Cajuru and Passaúna, corroborates to the results. The monitoring system was efficient for its purpose, in point out that the park meets with the functions and occurs conciliation, according to previously established criteria, while pointing out possible flaws failures in management and priority areas to guide management.

Key-words: Urban Park. Environmental Indicators. Scores. River Corridors. 


\section{LISTA DE FIGURAS}

Figura 1 - Vista parcial do processo de degradação do fundo de vale: início com as atividades agrícolas, urbanização e urbanização intensa.

Figura 2 - Representação gráfica das zonas tampão das florestas ripárias............................ 42

Figura 3 - Fases na implementação de um sistema de monitoramento

Figura 4 - Croqui do perfil da compartimentação geomorfológica estado do Paraná (EW) segundo Maack (1968).

Figura 5 - Etapas do sistema de monitoramento proposto.

Figura 6 - Matriz de equidade entre os índices dos indicadores analisados em campo.

Figura 7 - Vista parcial do Parque Municipal Nascentes do Belém, no Bairro Cachoeira em Curitiba-PR; em destaque na cor amarela os limites aproximados da área.

Figura 8 - Placa presente na entrada do Parque Municipal Nascentes do Belém, Curitiba$\mathrm{PR}$, com informações sobre os horários de visitação e restrições de uso nas dependências.

Figura 9 - Vista parcial das instalações do CRAS - Cachoeira, no Parque Municipal Nascentes do Belém.

Figura 10 - Vegetação lindeira ao curso hídrico no Parque Municipal Nascentes do Belém: (a) vegetação ao longo do canal; (b) vegetação próximo a nascente.

Figura 11 - Vista aérea do Parque Municipal Nascentes do Belém, em Curitiba-PR, e a ligação com áreas verdes adjacentes; em destaque circulado na cor vermelha os limites aproximados do parque.

Figura 12 - Síntese dos escores atribuídos aos indicadores de Conservação aplicados no Parque Municipal Nascentes do Belém, Curitiba- PR

Figura 13 - Sinalização no parque Municipal Nascentes do Belém: (a) placa de alerta na ponte da nascente; (b) sinalização no acesso com informações sobre dias e horários de funcionamento e condutas para o usuário.

Figura 14 - Vista das infraestruturas destinadas ao uso público no Parque Municipal Nascentes do Belém, Curitiba-PR: (a) trilha entre a vegetação sentido a ponte da nascente; (b) escadaria entre a ponte e o mirante; (c) vista do mirante para o lago da nascente e a ponte.

Figura 15 - Síntese gráfica dos escores atribuídos aos indicadores de Uso Público aplicados no Parque Municipal Nascentes do Belém, Curitiba-PR.

Figura 16 - Síntese gráficas dos índices de Conservação x Uso Público no Parque Municipal Nascentes do Belém, Curitiba (Paraná). 
Figura 17 - Matriz de equidade entre o Índice de Conservação (IC) e o Índice de Uso Público no Parque Municipal Nascentes do Belém, Curitiba-PR; em destaque na Coluna 1 e Linha 4 (14), a classificação do referido Parque Baixa Equidade.

Figura 18 - Vista geral do portal de acesso para o Parque Linear Cajuru na Rua Santa Lúcia, Curitiba, Paraná.

Figura 19 - Vista parcial da ocupação da margem hídrica no Parque Linear Cajuru, Curitiba-PR: (a) encontro do córrego da Rua Teófilo Otoni com o Rio Atuba; (b) aspecto parcial da vegetação e mobiliários de uso público lindeiros ao Rio Atuba.

Figura 20 - Vista aérea do Parque Linear Cajuru e uso e ocupação da terra predominante (urbanização) em áreas lindeiras; em destaque na cor vermelha, o início (ao norte) e o término (ao sul) dos limites aproximados da área.

Figura 21 - Síntese gráfica dos escores atribuídos aos indicadores de conservação aplicados no Parque Linear do Cajuru, Curitiba, Paraná.

Figura 22 - Vista parcial das áreas de recreação no Parque Linear do Cajuru, CuritibaPR, onde nota-se a ausência de Lixeiras.

Figura 23 - Vista parcial dos equipamentos de uso público no Parque Linear Cajuru, Curitiba-PR: (a) aspecto parcial da quadra poliesportiva; (b) aspecto parcial da pista de skate.

Figura 24 - Síntese gráfica dos escores atribuídos aos indicadores de uso público aplicados no Parque Linear Cajuru, Curitiba, Paraná.

Figura 25 - Matriz de equidade entre o Índice de Conservação (IC) e o Índice de Uso Público no Parque Linear Cajuru, Curitiba-PR; em destaque na Linha 3 e Coluna 3 (33), a classificação do referido Parque - Moderada Equidade.

Figura 26 - Localização do Parque Municipal Passaúna, Curitiba, Paraná; em destaque na cor vermelha limites aproximados da área e localização dos portais de acesso: Ponto A - entrada no final da Rua Eduardo Sprada; Ponto B entrada na Rua Angelo Marqueto.

Figura 27 - Vista parcial do mirante para a represa e da placa sobre o histórico de inundação do parque Municipal Passaúna (Curitiba-PR).

Figura 28 - Aspecto geral da pista de caminhada lindeira ao curso hídrico no Parque Municipal Passaúna, Curitiba, Paraná.

Figura 29 - Vista por satélite do Parque Municipal Passaúna (na cor amarela) em Curitiba (PR), e fragmentos de vegetação (identificados na cor verde) em seu entorno imediato.

Figura 30 - Síntese gráfica dos escores atribuídos aos indicadores de conservação aplicados no Parque Municipal Passaúna, Curitiba, Paraná. 
Figura 31 - Vista parcial da área de estacionamento próximo ao mirante no Parque Municipal Passaúna (Curitiba-PR), onde não se evidencia a presença de lixeiras.

Figura 32 - Vista parcial da presença de lixeiras no Parque Municipal Passaúna (CuritibaPR): (a) lixeira na trilha de acesso ao mirante; (b) lixeira próximo a pista de caminhada lindeira a represa.

Figura 33 - Vista parcial de Sinalização no Parque Municipal Passaúna (Curitiba-PR): (a) placa de alerta para conduta de usuários, próximo à pista de caminhada e a represa; (b) placa com informações referentes aos horários de visitação no portal de acesso da Rua Angelo Marqueto; (c) área de estacionamento com sinalização sobre o mirante e área de recreação infantil; e (d) sinalização no mirante sobre o histórico de inundação.

Figura 34 - Vista parcial dos sanitários nas dependências do Parque Municipal Passaúna (Curitiba-PR): (a) lanchonete e sanitários em propriedade particular; (b) sanitário público.

Figura 35 - Vista parcial da área para recreação infantil, no Parque Municipal Passaúna (Curitiba-PR).

Figura 36 - Síntese gráfica dos escores atribuídos aos indicadores de uso público aplicados no Parque Linear Cajuru, Curitiba, Paraná.

Figura 37 - Síntese gráfica do Índice de Conservação (IC) x Índice de Uso Público (IUP) no Parque Municipal Passaúna, Curitiba-PR.

Figura 38 - Matriz de equidade entre o Índice de Conservação (IC) e o Índice de Uso Público no Parque Municipal Passaúna, Curitiba-PR; em destaque na Coluna 2 e Linha1 (21), a classificação do referido Parque - Boa Equidade... 102

Figura 39 - Síntese dos Índices de Conservação e de Uso Público nos Parques Municipais: Nascentes do Belém, Cajuru e Passaúna, em Curitiba Paraná...... 102

Figura 40 - Relação dos escores atribuídos aos indicadores de conservação nos Parques Municipais: Nascentes do Belém, Passaúna e Cajuru, em Curitiba, Paraná..... 104

Figura 41 - Relação dos escores atribuídos aos indicadores de Uso Público nos Parques Municipais: Nascentes do Belém, Passaúna e Cajuru, em Curitiba, Paraná..... 105 


\section{LISTA DE TABELAS}

Tabela 1 - Relação entre os atrativos oferecidos em Parques Urbanos e a busca pelos usuários em valores percentuais $(\%)$.

Tabela 2 - Parques e Bosques curitbanos em área $\left(\mathrm{m}^{2}\right)$; em destaque as áreas selecionadas para os estudos de casos.

Tabela 3 - Classificação e escalonamento dos Indicadores de Conservação.

Tabela 4 - Classificação e escalonamento dos Indicadores de Uso Público.

Tabela 5 - Ponderação dos indicadores analisados.

Tabela 6 - Classes de cumprimento às funções dos Parques Urbanos de acordo com o índice

Tabela 7 - Síntese dos indicadores de conservação e uso público e suas respectivas pontuações e índices no Parque Municipal Nascentes do Belém, Curitiba, Paraná.

Tabela 8 - Síntese dos indicadores de conservação e uso público e seus respectivos escores e índices no Parque Linear Cajuru, Curitiba, Paraná.

Tabela 9 - Síntese dos indicadores de conservação e uso público e suas respectivas pontuações e índices no Parque Municipal Passaúna, Curitiba, Paraná.

Tabela 10 - Relação da densidade demográfica por bairros dos Parques analisados em Curitiba, Paraná. 


\section{SUMÁRIO}

1 INTRODUÇÃ

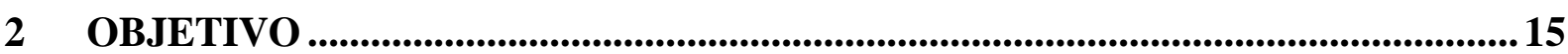

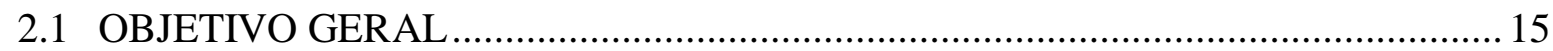

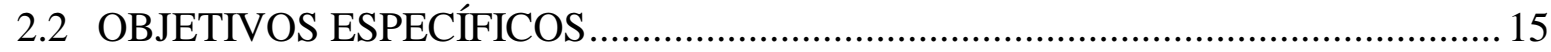

3 HIPÓTESE .............................................................................................................. 16

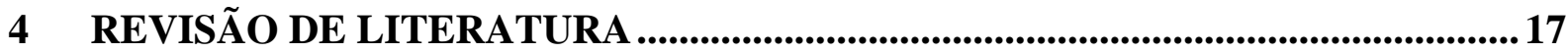

4.1 CONSIDERAÇÕES SOBRE A PAISAGEM URBANA ….................................... 17

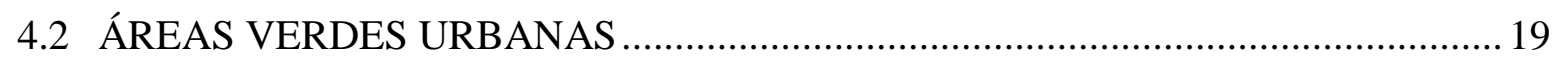

4.2.1 Aspectos conceituais ....................................................................................................... 19

4.2.2 Áreas verdes como medida saneadora............................................................2 21

4.2.3 Benefícios das Áreas Verdes...................................................................... 23

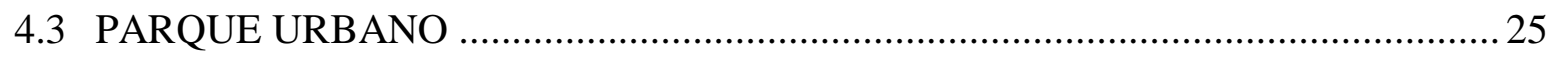

4.3.1 Desenho dos primeiros parques ....................................................................... 25

4.3.2 Os parques urbanos na atualidade .......................................................... 28

4.3.3 Classificação dos parques urbanos ................................................................ 31

4.3.4 Estado da arte: estudos sobre parques urbanos no cenário brasileiro...........34

4.4 O FUNDO DE VALE COMO ÁREA ESTRATÉGICA PARA CONSERVAÇÃO DA NATUREZA NA CIDADE............................................................................... 35

4.4.1 Vegetação ciliar como ferramenta na conservação ..................................... 40

4.5 ANÁLISE E MONITORAMENTO DE PAISAGENS ........................................... 43

4.5.1 Indicadores como instrumento na análise de paisagens.................................. 46

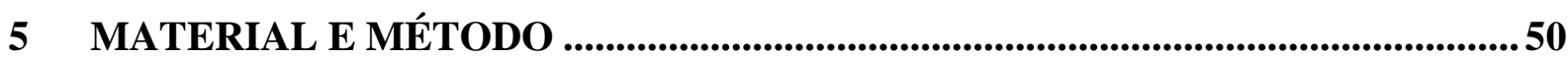

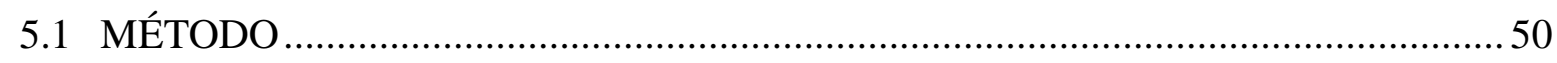

5.2 CARACTERIZAÇÃO MACRO DA ÁREA DE ESTUDO....................................... 51

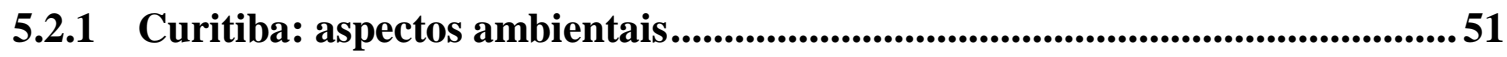

5.2.2 Caracterização do contexto estudado .......................................................53 
5.2.2.1 Produção dos espaços verdes em Curitiba.................................................53

5.3 PROCEDIMENTOS TÉCNICO-OPERACIONAIS …........................................... 56

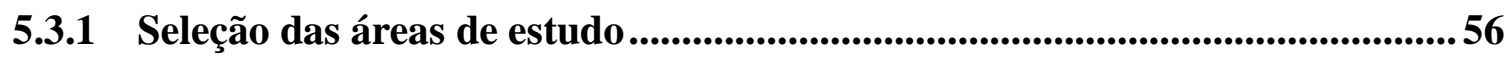

5.3.2 Desenvolvimento do sistema de monitoramento ..............................................57

5.3.3 Seleção, caracterização e avaliação dos indicadores........................................... 59

5.3.4 Critérios para classificação dos indicadores .................................................. 65

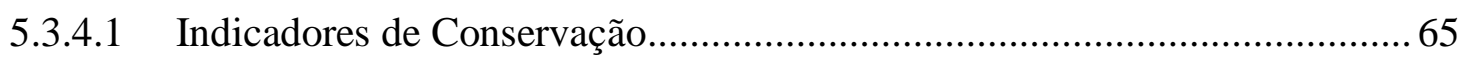

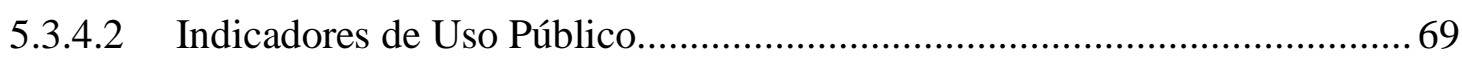

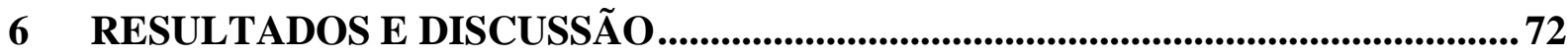

6.1 PARQUE MUNICIPAL NASCENTES DO BELÉM.......................................... 72

6.1.1 Indicadores de Conservação ............................................................................... 74

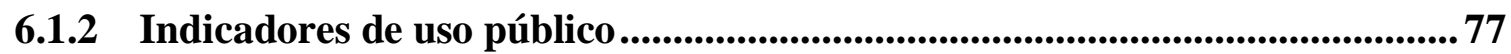

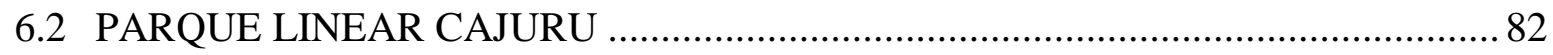

6.2.1 Indicadores de Conservação ................................................................................ 83

6.2.2 Indicadores de Uso Público .............................................................................. 87

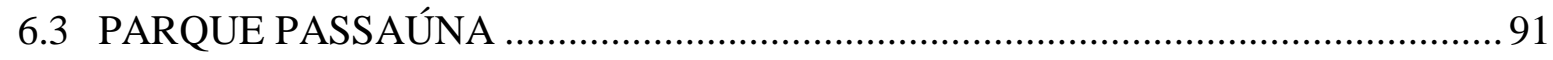

6.3.1 Indicadores de Conservação ...................................................................................... 93

6.3.2 Indicadores de Uso público ..................................................................................96

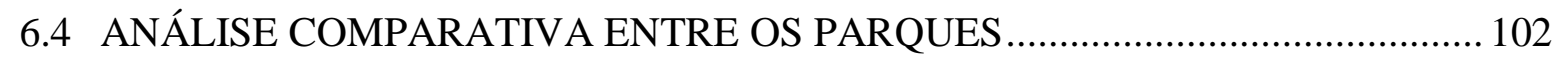

6.5 MEDIDAS NORTEADORAS A GESTÃO DOS PARQUES ANALISADOS........ 105

6.5.1 Parque Municipal Nascentes do Belém ........................................................ 106

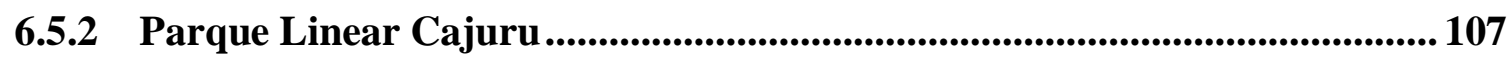

6.5.3 Parque Municipal Passaúna....................................................................... 108

7 CONCLUSÕES E CONSIDERAÇÕES FINAIS ......................................................... 109

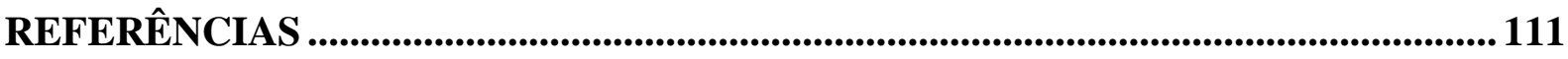

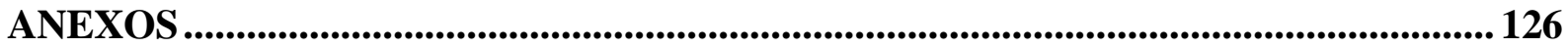

ANEXO A - Bacias Hidrográficas de Curitiba, Paraná ................................................. 127 
ANEXO B - Sistema hidrográfico de Curitiba-PR e áreas sujeitas a inundações

ANEXO C - Lei Municipal No 9.804/2000

ANEXO D - Vista parcial da localização do Bairro Cachoeira na cidade de Curitiba PR, em destaque o Parque Municipal Nascentes do Belém.

ANEXO E - Vista parcial do Parque Municipal Linear Cajuru em relação ao Bairro Cajuru, Curitiba-PR

ANEXO F - Vista parcial do Parque Municipal Passaúna em relação ao Bairro Augusta, Curitiba-PR 


\section{INTRODUÇÃO}

Os parques urbanos são espaços públicos com área geograficamente delimitada, com dimensões espaciais representativas e a predominância de vegetação arbóreo-arbustiva, as quais podem se constituírem de fragmentos florestais estrategicamente preservados pelos governos locais e/ou áreas que sofreram reabilitação após anos de degradação ambiental. Apresentam funções estéticas, ecológicas, lazer e recreação, sendo consideradas como a principal área de recreação e lazer da população urbana, além da conservação dos sistemas naturais nas cidades (KLIASS, 1993; SOLECKI; WECH, 1995; SORENSEN et al., 1998; ALVAREZ, 2004; OLIVEIRA, 2007). Para que estes espaços possam cumprir com suas funções, a administração pública deve manejar e gerenciar de forma equitativa os elementos ecológicos, estéticos e de recreação e lazer.

Entretanto, verifica-se uma maior atenção para as funções estéticas e sociais. Observase, por exemplo, pistas de caminhadas e mobiliários de uso público em áreas que originalmente eram íngremes e alagadas, além da introdução de espécies exóticas da flora para fins paisagísticos. É o caso dos Parques Barigui e São Lourenço em Curitiba o Parque do Carmo em São Paulo. Tais fatores interferem na manutenção dos sistemas naturais (hídrico, físico e ecológico), por permitirem que as infraestruturas para visitantes em áreas frágeis (planície de inundação e encosta) modifiquem os aspectos físicos do relevo e da várzea, e a introdução de espécies exóticas à unidade fitogeográfica em questão, passem a competir ecologicamente com as espécies nativas, comprometendo a conservação in situ deste ambiente.

Embasando-se nestes pressupostos, o parque passa a assumir um caráter mais saneador do que conservacionista, pois os benefícios advindos da conservação dessas áreas associam-se diretamente ao ser humano, tais como melhoria nas condições microclimáticas, controle de poluição e áreas para lazer e recreação. Assim, a função de conservação física e ecológica torna-se pontual por proteger "esse" ou "aquele" recurso, não contribuindo para a conservação da paisagem de forma integrada.

Comumente, os estudos sobre a temática no cenário brasileiro focam a interação entre usuário e parque (REIS, 2001; SILVA, 2003; TEIXEIRA, 2007; CORADINI, 2008; ALVES; RAIMUNDO, 2009), ou estudos de caso sobre a ecologia de espécies de flora ou fauna (SOUZA, 2011; NASCIMENTO, 2005; BIONDI; MULLER, 2013). Fazem-se necessários estudos que tenham como foco o desenvolvimento de técnicas de avaliação e monitoramento, 
para subsidiar a gestão destes ambientes com o intuito de assegurar a equidade e conciliação entre o uso público e a conservação, e a manutenção dos aspectos naturais, uma vez que ambas as funções são necessárias para o desempenho ecológico e social desses espaços. Oliveira e Bitar (2009) ressaltam que são poucos os trabalhos publicados que abordam indicadores aplicáveis ao monitoramento de parques urbanos. Assim ocorre uma lacuna no que diz respeito ao cumprimento equitativo das funções destes espaços.

Norteado pelas indagações: "o parque urbano de fundo de vale cumpre com as funções de conservação e uso público?" e "existe conciliação entre tais funções?", esta pesquisa tem por objetivo central demonstrar a potencial ineficiência dos Parques Urbanos quanto à conciliação entre as funções de uso público e conservação, por meio de um sistema de indicadores aplicados ao monitoramento de parques urbanos com tipologias ecológicas localizados em fundos de vale, com o intuito de avaliar o desempenho dessas funções e identificar a melhor forma de gestão equilibrada entre elas. Para tal conduziu-se estudos de casos múltiplos na cidade de Curitiba (Paraná) onde os indicadores foram qualificados e mensurados com o intuito de testar a replicabilidade do sistema desenvolvido.

Cabe ressaltar que no âmbito científico, tal pesquisa pode subsidiar trabalhos de campo com caráter de gestão e planejamento ambiental e abrir um novo leque de discussão para a formatação de variáveis e indicadores compatíveis com as necessidades atuais.

Esta pesquisa estrutura-se em quatro macros seções: a primeira intitulada de "Revisão de Literatura" consiste nos aportes teóricos que subsidiam a pesquisa de campo, tais como a conceituação, definição e processo de formação dos parques urbanos, fundos de vale e indicadores ambientais; a segunda, "Material e Métodos", descreve o método adotado e os procedimentos técnicos empregados, delineando a formatação dos indicadores aplicados em campo bem como sua qualificação; a terceira intitulada de "Resultados e Discussão" analisa e interpreta os dados obtidos, além de tecer paralelos com estudos conduzidos nas áreas, por meio de técnicas diferenciadas, com o intuito de ressaltar tais resultados; a quarta e última seção "Conclusões e Considerações Finais", discorre sobre a refutação das hipóteses iniciais, bem como o apontamento de potenciais lacunas identificadas ao longo da pesquisa e os pontos positivos averiguados. 


\section{OBJETIVO}

\subsection{OBJETIVO GERAL}

Demonstrar a potencial ineficiência dos Parques Urbanos quanto à conciliação entre as funções de Conservação e Uso Público.

\subsection{OBJETIVOS ESPECÍFICOS}

- Desenvolver um sistema de monitoramento por meio de indicadores que permitam inferir o grau de equidade entre as funções de uso público e conservação;

- Realizar estudos de caso múltiplos para testar a replicabilidade da técnica;

- Analisar por meio dos indicadores se existe equipamentos para subsidiar o cumprimento da função de uso público;

- Analisar por meio dos indicadores se a área permite condições para a manutenção dos aspectos físicos e ecológicos;

- Identificar o grau de conciliação/equidade entre as funções de uso público e conservação;

- Identificar e apontar zonas necessárias para intervenção nos ambientes estudados. 


\section{HIPÓTESE}

O parque Urbano não cumpre de forma equitativa com as funções de uso público e conservação.

Os modelos de parques urbanos existentes não foram projetados paisagisticamente para conciliar as funções de conservação e de uso público, uma vez que equipamentos de lazer e afins são instalados em áreas que deveriam ser destinadas a conservação, tais como pistas de caminhadas em áreas de vegetação ciliar. Portanto, a manutenção da conservação passa a ter um caráter secundário frente ao uso público. 


\section{REVISÃO DE LITERATURA}

\subsection{CONSIDERAÇÕES SOBRE A PAISAGEM URBANA}

A cidade é uma construção no espaço em grande escala, algo apenas perceptível no decurso de longos períodos de tempo, ou seja, a cidade é moldada pelos homens e retrata o contexto histórico das civilizações (LYNCH, 1995).

Analisando a cidade sob a ótica das intervenções humanas, Forattini (1991) destaca que estes espaços constituem em um sistema antrópico, onde grau de artificialidade atingiu seu nível mais elevado.

Delpoux (1974) identifica o espaço urbano como uma paisagem importadora de energia: os produtores de matéria orgânica com valor energético não existem ou são insuficientes; a comunidade viva só se perpetua devido ao fornecimento de energia exterior. Caracterizando um sistema em desequilíbrio.

Assim, o desenvolvimento do urbano resulta em intensa e profunda manipulação do ambiente, decorrendo modificações que recaem sobre a paisagem e a comunidade (FORATTINI, 1991).

Para Figueiró (2011), a cidade representa historicamente o lócus privilegiado onde se materializa com maior evidência, e se agudiza, a relação entre a sociedade e a natureza. Neste sentido, a transformação da paisagem urbana, e os seus impactos associados são produto e processo dos conflitos de uma sociedade heterogênea que busca se estabelecer sobre um espaço com condições físicas naturalmente diferenciadas.

A cidade constitui evidentemente um complexo sistema humano, mas, longe de ser um deserto para outras formas de vida, ele cria uma variedade de ambientes, que são colonizados por seres vivos. Alguns deles são variantes das condições naturais (parques e jardins), mas outros são totalmente artificializados. As espécies adaptáveis conseguem viver nas cidades e, em certos casos, proliferam, a exemplo dos ratos (Rattus sp.), insetos e algumas plantas (como exemplo a Leucaena leucocephala) que invadem rapidamente os solos degradados (DREW, 2011).

Por mais que a paisagem seja transformada, continua como parte da natureza, subordinando-se às leis naturais; o homem somente se utiliza das leis naturais para alcançar seus propósitos, modificando, espontânea ou conscientemente, a direção e a velocidade da evolução paisagística (RODRIGUEZ; SILVA; CAVALCANTI, 2007). 
Podem-se enumerar, de maneira genérica, as características do ambiente urbano: $i$ ) afastamento e ausência de contato com o meio natural; ii) concentração e elevada densidade populacional; iii) predominância de atividade industrial e de prestação de serviço (FORATTINI, 1991).

Verifica-se neste contexto a necessidade da presença de elementos nas cidades que subsidiem condições para a manutenção dos sistemas naturais, buscando assim equilíbrio nas relações entre o espaço construído e o natural.

\begin{abstract}
O grande desafio para a humanidade neste novo século é a afirmação de um modelo conservacionista que, superando a perspectiva do "intocável", consiga aliar a preservação ambiental às inevitáveis e crescentes funções urbanas do mundo contemporâneo (FIGUEIRÓ 2011, p.181).
\end{abstract}

No processo de transformação antropogênica, o homem modifica a natureza, pois introduz elementos novos, comumente danosos. Esses elementos experimentam e subordinam-se à ação dos processos naturais e neste fundo natural, não são por completo estáveis e não são capazes de existir independentemente sem o apoio e sustentação constante por parte do homem. Quando ausente à manutenção humana, a natureza agrega esses elementos como se fossem corpos estranhos: culturas ou animais domésticos desaparecem ou tornam-se selvagens, os desmatamentos convertem-se em bosques; os edifícios destroem-se. Todas essas situações ocorrem, quando são interrompidas, a manutenção humana (RODRIGUEZ; SILVA; CAVALCANTI, 2007), assim os sistemas ambientais buscam uma nova estabilidade.

Quando cessada a intervenção humana (de alta magnitude), a paisagem busca uma nova estabilidade, de tal forma, que qualquer paisagem modificada ou transformada pelo homem tende a ser menos estável que uma paisagem sem intervenções; pois o mecanismo natural de auto-regulação é alterado. Por isto, qualquer desvio extremo dos parâmetros do meio exterior que é amortizado ou absorvido na paisagem natural pode ser catastrófico para uma paisagem antropogênica. O homem contribui para desenvolver tendências "ocultas", a ser um mecanismo desencadeante de processos latentes, pondo em ação relações negativas inversas. Ela ocorre no caso em que a paisagem está preparada para dar impulso a processos inerentes como tendência natural, como nas paisagens em equilíbrio instável, que evoluem rapidamente, as paisagens relíquias e aquelas que se encontram em condições extremas (RODRIGUEZ; SILVA; CAVALCANTI, 2007).

A que se ressaltar que o equilíbrio é dinâmico, porém as ações humanas afetam de tal 
forma a resiliência dos sistemas ambientais, que coíbe a paisagem de se autorregular em escala de tempo humano.

Todos os aspectos do ambiente são alterados pela urbanização e industrialização, inclusive o relevo, uso da terra, a fauna, hidrologia e o clima. A intensidade da mudança relaciona-se diretamente à densidade da área edificada e a extensão da industrialização, as áreas urbanas horizontais, com muitos espaços verdes costumam alterar menos o ambiente que os centros industrializados compactados e verticais (DREW, 2011).

Para Cavalheiro (1995) não basta que se tome mão apenas de medidas tecnológicas para controle das degradações ambientais; o mais lógico consiste em tirar partido do que a natureza pode oferecer no tocante à autorregeneração, para então estudar quais devem ser as tecnologias mais compatíveis a serem utilizadas.

A mudança da funcionalidade ambiental, o empobrecimento biológico e os altos custos para a recuperação de áreas degradadas são apenas algumas das marcas deste aumento da entropia produzido pela urbanização acelerada e sem controle (FIGUEIRÓ, 2011).

Ao considerar estes pressupostos, a cidade deve ser pensada e edificada de forma que se permita a manutenção de elementos naturais. Nas palavras de McHarg (1971) a cidade deve ser "desenhada com a natureza", onde as características naturais do espaço sejam fatores limitantes ao seu desenvolvimento.

Assim, nesta pesquisa a paisagem é interpretada sobre a ótica de Monteiro (2000):

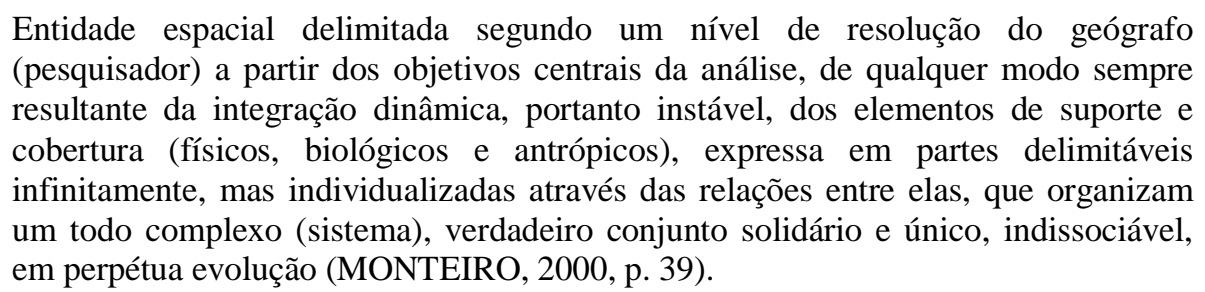

\section{2 ÁREAS VERDES URBANAS}

\subsubsection{Aspectos conceituais}

A formação do ambiente urbano e a conservação da natureza seguem direções opostas. Comumente as cidades se edificam, sem considerar os aspectos naturais. Os elementos naturais existentes corriqueiramente apresentam uma conotação de serviço para o homem, seja lazer, recreação, social, estético ou econômico.

As pessoas e seus organismos são influenciados pelo ambiente em que vivem. $\mathrm{O}$ 
ambiente citadino foi o espaço para o qual o homem transferiu-se do habitat natural para um habitat construído. Numa visão romântica, os espaços verdes seriam uma possibilidade de o homem citadino vivenciar as mudanças das estações, o funcionamento da natureza e se aproximar do seu espaço de origem (SILVA, 2003).

Nas cidades, comumente as áreas de conservação da natureza são representadas pelas áreas verdes, que correspondem a uma das categorias dos espaços livres de construção, cujo planejamento visa atender a demanda da comunidade urbana por espaços abertos que possibilitem a recreação, o lazer e a conservação da natureza (MAZZEI; COLESANTI; SANTOS, 2007).

Lima et al. (1994) conceituam áreas verdes como espaços onde ocorre a predominância de vegetação arbórea, englobando as praças, os parques urbanos, trevos de vias públicas e canteiros centrais. Mazzei, Colesanti e Santos (2007) ressaltam que a vegetação é o elemento fundamental de composição paisagística de uma área verde.

Para Oliveira (1996), áreas verdes são espaços abertos e permeáveis, públicos ou privados, com cobertura vegetal predominantemente arbórea ou arbustiva, que apresentem funções de melhoria na qualidade ambiental-urbana, bem como benefícios de ordem social, econômica e ecológica.

Em complemento, Cavalheiro et al. (1999) ressaltam que o elemento fundamental da composição de uma área verde é a vegetação. Esses espaços devem satisfazer a três principais objetivos: ecológico-ambiental, estético e de lazer. Vegetação e solo permeável devem ocupar pelo menos $70 \%$ da área; devem servir à população, proporcionando um uso e condições para recreação. Canteiros, pequenos jardins de ornamentação, rotatórias e arborização não fazem parte do sistema de áreas verdes, mas sim ao verde de acompanhamento viário.

Verifica-se que a literatura referente à temática pode ser falha, por excluir alguns outros verdes urbanos que não se enquadram em nenhuma categoria descrita anteriormente, tais como fragmentos florestais e Áreas de Preservação Permanente (APPs) presentes na paisagem urbana.

Grey e Deneke (1978) utilizam a terminologia "urban forestry" (floresta urbana/arborização urbana) para expressar a vegetação presente no meio urbano. Segundo estes, a floresta urbana inclui todas as áreas com vegetação lenhosa no território urbano incluindo a vegetação de acompanhamento viário, do sistema hidrográfico, áreas públicas destinadas à recreação e lazer, como parques, praças, jardins, e áreas privadas como jardins e similares.

Biondi (2000) apresenta uma interessante classificação para o verde urbano: i) 
vegetação de acompanhamento viário; ii) áreas verdes urbanas - praças, Unidades de Conservação (UCs) e Áreas de Preservação Permanente (APPs); e iii) vegetação privada e semiprivada, vegetação de áreas particulares como jardins.

Independentemente do conceito adotado é indiscutível a importância e o papel que estas áreas desempenham em uma cidade (HILDEBRAND; GRAÇA; HOEFLICH, 2002).

Para fins desta pesquisa, consideram-se áreas verdes urbanas, todos os espaços existentes na cidade onde ocorram a predominância de vegetação arbóreo-arbustiva e o uso público. A tipologia de área verde a ser pesquisada é o Parque Urbano.

\subsection{2 Áreas verdes como medida saneadora}

A concepção de planejar a cidade com áreas verdes, como forma de saneamento, tem sua essência na Inglaterra pós-industrial, final do século XIX, devido às necessidades das populações por uma cidade mais salubre. Uma vez que a urbe não contemplou em seu desenho inicial o exuberado crescimento demográfico, apresentando péssimas condições de moradia e higiene.

Segundo Howard (1996) a força motriz dos problemas urbanos, concentravam-se no processo de migração, visto que as cidades cresciam rapidamente, não comportando essas novas populações (caso londrino).

Para o referido autor (HOWARD, 1996), seria necessária uma integração entre campo e cidade, baseado neste princípio e com o viés de sustentabilidade ambiental urbana, Howard propõe o conceito e projeto de cidades jardins, publicadas originalmente em 1898 a qual oportunamente apresentava-se como alternativa para os problemas vivenciados na Inglaterra pós-industrialização.

Nos projetos de Howard (1996) predominam sempre a ideia de jardim e campo permeando a área construída, assim o projeto de cidade jardim teria sempre uma cidade matriz, que consistiria na cidade maior, circunvizinhadas por cidades menores e áreas rurais.

Howard (1996) concebe ideias sanitárias, como cinturões verdes as margens indústrias para amenizar ruídos e poluentes atmosféricos; destinação final de resíduos orgânicos como composto para agriculta e ajardinamento. Quando a cidade atingisse sua capacidade de suporte deveriam ser formadas novas cidades próximas interligadas por ferrovias e rodovias.

Em 1903, Letchwoth, a primeira cidade jardim é projetada na Inglaterra; em 1919 próximo a Letchwoth é instalada a segunda, Welwin. 
A cidade jardim tem reflexos na produção de outros espaços urbanos pelo mundo, porém não é concebida em sua totalidade, principalmente no que diz respeito aos princípios cooperativistas, comerciais e sociais.

No Brasil esta influência apresenta-se de várias maneiras. Em São Paulo a partir de 1913, instala-se a "City of São Paulo Improvements and Freehold Company Ltd"; a qual começa a projetar bairros e regiões centrais nos moldes das cidades jardins; no Rio de Janeiro o urbanista francês Alfred Agache em seu plano "A Cidade do Rio de Janeiro - Extensão, Remodelação, Embelezamento" (1930), propõe duas Cidades-Jardins, para as ilhas do Governador e Paquetá, além de inúmeros loteamentos que seguiram tais princípios por toda a cidade; no plano de Goiânia (1933), de Atilio Corrêa Lima, a zona residencial ao sul da cidade é constituída por ruas curvas, com inúmeros "cul de sac" e extensa vegetação, lembrando o sistema empregado nas duas Cidades-Jardins inglesas (HOWARD, 1996).

No Norte do Paraná na primeira metade do século XX, a Companhia de Terras do Norte do Paraná (CTNP) e a Companhia Ferroviária São Paulo-Paraná, subsidiárias da companhia inglesa Paraná Plantation Ltd. (fundada em Londres em 1925 e liquidada em 1944), na área compreendida entre Londrina (a filha de Londres) e Maringá, "plantou" estas e outras dez cidades com influências de Cidades-Jardins ao longo de pouco mais de cem quilômetros (REGO, 2009). Já em Curitiba, verifica-se grande influência das Cidades-Jardins em 1943, por meio do Plano Agache realizado pelo urbanista Alfred Agache (IPPUC, 2014).

Seguido pelo modelo inglês, vários governos utilizaram como exemplo a fim de resolver a situação das cidades industriais. Os princípios sanitários começaram a ter destaque no planejamento, constituindo-se em um dos primeiros mecanismos de uma política urbanística (CASTELNOU NETO, 2005).

De locais de contemplação e reaproximação com o mundo natural, os jardins e parques urbanos passaram a adquirir conotações funcionalistas, que iam desde os interesses científicos e de colecionismo burguês até as justificativas higienistas que, juntamente com as preocupações como ventilação e iluminação natural, começaram a se tornar frequentes no planejamento urbanístico (CASTELNOU NETO, 2005).

Inúmeras cidades foram reestruturadas adotando-se medidas que visavam à amplidão e beleza dos espaços, por meio do alargamento de ruas e da criação de parques e praças (BAHLS, 1998).

O gosto pelo "verde" desenvolveu na população, o hábito de cultivar árvores e flores. Os jardins representavam ambientes harmoniosos, belos, silenciosos, a antítese da cidade, cujo barulho das fábricas e a poluição impediam a existência de uma vida tranquila e 
saudável, para uma população que era acostumada com a paisagem do campo. A vegetação, que fora banida da área urbana, passou a (re)integrá-la, através da criação de praças e parques. No século XIX os jardins urbanos eram considerados instrumentos eficazes para combater o congestionamento e a desordem das grandes cidades, embelezar o ambiente e servir de área de recreação para a população, além de suas funções sanitárias. Estas novas formas de se pensar o espaço urbano difundiram-se pelo mundo (BAHLS, 1998).

No Brasil, Rodrigues Alves, ao assumir a Presidência da República, em 1902, procurou pôr em prática suas promessas de campanha fundamentadas no saneamento da capital (Rio de Janeiro). Assim nomeou como prefeito do Rio de Janeiro o engenheiro Francisco Pereira Passos (1903-1906), cuja responsabilidade era a de transformar urbanisticamente a capital; para tanto, contratou o Médico Oswaldo Cruz para realizar uma completa reforma sanitária (BAHLS, 1998).

Oswaldo Cruz elaborou uma detalhada campanha que atingia residências, logradouros e demais locais públicos, procurando evitar a propagação de doenças nesses espaços. Seus preceitos sanitários iam do estabelecimento de áreas próprias para a lavagem de roupas, divisão das casas, lugares para preparação de alimentos e criação de um reservatório de água protegido de insetos, vacinação obrigatória da população e preservação de áreas verdes. $\mathrm{O}$ projeto também previa a arborização de jardins públicos e praças, a fim de tornar os logradouros espaços mais atraentes (BAHLS, 1998).

\subsubsection{Benefícios das Áreas Verdes}

A vegetação exerce grande influência sobre os fatores ambientais, apresentando-se como um dos componentes mais importantes da cidade por propiciar à população o contato com a natureza e auxiliar na mitigação de potenciais impactos ambientais associados às alterações do meio físico; também atua no equilíbrio ecológico urbano. Sua ausência, muitas vezes, relaciona-se a problemas ambientais como inundações e movimentação de massa (ROCHA, 2007).

Dessa forma as áreas verdes configuram-se como uma medida saneadora. Os benefícios podem ser classificados sob a ótica física (melhorias microclimáticas e controle de poluição), econômica e social. 


\section{Benefícios sobre os aspectos físicos do ambiente}

A vegetação atua principalmente em quatro fatores microclimáticos: $i$ ) temperatura, ii) umidade, iii) radiação solar, e iv) velocidade do vento (BARBOSA, 2005; MASCARÓ; MASCARÓ, 2002).

A influência das áreas verdes nas condições higrotérmicas dos ambientes urbanos ocorre pela interceptação e captação de energia solar incidente. O maior ou menor grau dessa interceptação depende diretamente da área ocupada, e estrutura da vegetação (BARBOSA, 2005).

As temperaturas urbanas ao entorno de áreas vegetadas apresentam menores oscilações entre as temperaturas máximas e mínimas; durante o verão as temperaturas superficiais dos pavimentos e fachadas da edificação são menores assim como a sensação de calor da população (MASCARÓ; MASCARÓ, 2002).

A filtragem da radiação solar reflete-se na intensidade luminosa e na temperatura, assim, se aceita como regra geral, que a vegetação tende a suavizar as temperaturas extremas (ALVAREZ, 2004).

$\mathrm{O}$ efeito sobre o conforto térmico vai depender muito do meio que o circunda. As diferentes superfícies apresentam variação em relação à absorção, reflexão (albedo) e transmissão de radiação solar (ALVAREZ, 2004).

Áreas verdes com áreas permeáveis interceptam e retêm no solo as águas pluviais, aumentando a capacidade de infiltração da bacia reduzindo o escoamento superficial. A planta ainda tem o potencial de atenuar o ressecamento do ar durante o processo de evaporação, assim a água interceptada umidifica o ar (BARBOSA, 2005). Verifica-se que maiores índices de umidade apresentam melhor qualidade de ar e temperaturas com menores variações; áreas com vegetação podem apresentar redução de temperaturas no verão de 6 a $8^{\circ} \mathrm{C}$ em relação a áreas não arborizadas (CAVALHEIRO, 1994).

As árvores reduzem a velocidade dos ventos e podem criar zonas de conforto ao controlar o vento por obstrução, condução, desvio, e filtração (GREY; DENEKE, 1978). Assim, a vegetação de porte arbóreo pode prevenir e/ou amenizar possíveis danos ocasionados por correntes de ventos fortes.

\section{Controle de Poluição}

A vegetação atua como filtros na poluição atmosférica. $O$ gás carbônico é absorvido durante o processo de fotossíntese (GONÇALVES; KRIEGER, 2004). A fixação do material particulado presente no ar é depurada de forma mecânica: as partículas são sedimentadas na 
superfície da planta de maneira eletrostática e a fixação do material se dá pelo contato com gotículas de água presentes no vegetal (BARBOSA, 2005). Frente a esta funcionalidade da vegetação, Bernatzky (1980) aponta que, áreas vegetadas podem absorver $70 \%$ da poeira em suspensão e espécies caducas na estação seca podem reter até $60 \%$ dessas partículas.

Os espaços verdes ainda trabalham com a ambiência acústica da cidade ao amenizar ruídos (MASCARÓ; MASCARÓ, 2002; POSADA; ARROYAVE; FERNANDEZ, 2009). A vegetação pode amenizar o ruído pela absorção do som (elimina-se o som), pela difração (altera-se a direção do som), pela reflexão (as ondas sonoras mudam de direção ao redor de um objeto), por ocultamento (cobre-se o som indesejável) (MASCARÓ; MASCARÓ, 2002).

O porte da vegetação e a composição determinam quanto o ruído pode ser reduzido. Para frequências elevadas de som, as barreiras constituídas de folhagem são mais eficientes, sendo que esta eficiência aumenta com a densidade da folhagem, a largura e a espessura das folhas, uma barreira vegetal pode reduzir de 3 a 8 decibéis do total do ruído (SHIBAO, 1984).

\subsection{PARQUE URBANO}

\subsubsection{Desenho dos primeiros parques}

Os primeiros parques urbanos foram propostos em Munich (Alemanha) como espaços de recreação pública em 1789, utilizando-se de espaços até então em desusos. Entretanto, a acepção atual de áreas especificamente reservadas para a utilização pela população só foi desenvolvida no século XIX, por desenhos em áreas da Coroa Britânica (St. James Park e Regent's Park/1828) (MAGNOLI, 2006).

$\mathrm{O}$ auge da era industrial e a expansão urbana na Inglaterra consolidaram uma nova postura para as áreas verdes, possibilitando a formação de parques urbanos, cuja função primordial naquele momento, era responder as demandas para as atividades de recreação e lazer dessa nova população urbana; este fato atinge seu apogeu entre 1850 e 1860, repercutindo por toda a Europa (ARAÚJO, 2007).

De acordo com a trajetória evolutiva dos parques urbanos, verifica-se que o desenho paisagístico do século se dividia em três escolas: a) classicismo ocidental, proveniente do barroco italiano ou da monarquia francesa, que quase todos os estados quiseram copiar ou rivalizar; b) escola chinesa, da qual inicialmente a corte francesa quis se apropriar, apenas pelo lado da novidade e da frivolidade, sem se ater aos fundamentos filosóficos; c) escola 
inglesa, oposta ao classicismo ocidental, a favor de uma expressão totalmente nova e liberal, sem geometrismos (ARAÚJO, 2007).

Segundo Araújo (2007) a fonte de inspiração dos parques ingleses foi à ideia romântica "de volta à natureza", aliada a influência da arte e cultura orientais; em sua evolução o parque inglês passa a incorporar elementos pitorescos; essa nova acepção pode ser classificada como estilo paysager (nos países de língua inglesa) e gardenesque (na França). Londres possui até hoje uma extensa área verde no centro da cidade, formada pelo Saint James Park, Hyde Park, Green Park e Kensington Gardens; este ultimo de autoria de Joseph Paxtin, serviu de inspiração para o Central Park, em Nova York, criado por Frederic Law Olmsted e Calver Vaux (1858), passando a atender a necessidade de espaços amenizadores das estruturas urbanas, compensando as massas edificadas (ARAÚJO, 2007).

Esse modelo de parque influenciou todos os parques do período. No Brasil, o parque Ibirapuera (São Paulo), o Parque da Pampulha (Belo Horizonte), o Parque do Aterro (Rio de Janeiro). Ainda hoje continua servindo de modelo, como exemplo o Parque Barigui em Curitiba (ARAÚJO, 2007).

Na América do Norte o antagonismo à baixa qualidade de vida nas cidades devido à urbanização, bem como aos processos de exploração da natureza de cunho importante exercidas pela agricultura e pecuária (nos EUA), originou o movimento conservacionista do "Park Movment", o qual teve como principal fonte de inspiração as obras de George Perkins Marsh e Henry David Thoureau (ARAÚJO, 2007).

Magnoli (2006) apresenta uma leitura da evolução traçada por Cranz (1972) quanto às tipologias dos desenhos dos parques americanos.

Para cada um dos modelos o desenho faz uso dos mesmos elementos - água, árvores, flores, caminhos, vedos, esculturas, edificações - mas em combinações distintas e com diferentes predominâncias. Indica específicas metas sociais a atingir; diferentes são as maneiras de elaborar os mesmos elementos; a cada modelo corresponde uma intenção de contribuir para a solução de problemas decorrentes das transformações iniciadas pelos processos de industrialização e urbanização (MAGNOLI, 2006, p. 204).

O Pleausre Garden (1850 a 1900), caracterizado pelos trabalhos de Olmsted $^{1}$, é o parque constituído por amplo espaço, alternando em modelados suaves de pradarias e plácidas e extensas águas que serpenteiam entre as colinas onduladas; as águas refletem largas faixas de céu e massas de árvores de poucas espécies, criando diferentes sequências de espaços

\footnotetext{
${ }^{1}$ Frederic Law Olmested (1822-1903) paisagista responsável juntamente com o arquiteto Calvert Vaux pelo projeto do Central Park em Nova York (1853)
} 
sinuosos com caminhos bucólicos (MAGNOLI, 2006). É o cenário idealizado do campo; flores são evitadas por remeterem à mão do homem; áreas edificadas são reduzidas ao máximo e envolvidas entre pérgolas e vedos em pedras rústicas; esculturas e iluminação artificial são evitadas; caminho sinuoso com separação do trânsito de veículos e pedestres é a característica sistematicamente utilizada no modelo do período. Nenhum movimento mais dinâmico nas águas sem ruídos, nenhum contraste mais significativo na vegetação, ou detalhes a enfatizar observações mais reduzidas; a amplitude é sempre priorizada (MAGNOLI, 2006). São parques localizados além das periferias, onde as famílias e grupos encaminham-se para passear, andar de barco, carruagem, ouvir concertos e fazer piqueniques. Apresenta-se como antídotos da urbe - com sua jornada de trabalho exaustiva e epidemias que assolam o período (MAGNOLI, 2006).

Frederic Law Olmsted redefiniu com grande maestria o seu moderno traçado; inspirado no conceito naturalista dos parques ingleses do século XVIII, o conjunto de sua obra revolucionou os conceitos urbanísticos da época e se mantém até os nossos dias, influenciando os novos espaços verdes que se inserem nas malhas urbanas (ARAÚJO, 2007).

“Os trabalhos de Olmstead inspirou não somente a criação de numerosos parques nacionais, nos EUA e em todo mundo, como também mudou o conceito de qualidade ambiental urbana com a criação de vários parques (FRANCO, 2008, p. 83)".

No Brasil, a criação de parques no espírito do "Parks Movement", foi muito tardia. O primeiro parque nacional surgiu em 1937 com a criação do Parque Nacional do Itatiaia, excluindo-se o Parque da Tijuca, no Rio de Janeiro, criado em 1862, por iniciativa de D. Pedro II, e pelo esforço do Major Gomes Archer, o qual não foi criado por influências externas, mas pelo simples motivo da conhecida falta da água na cidade do Rio de Janeiro (FRANCO, 2008).

O período de 1900 a 1930 caracteriza grandes mudanças na concepção dos parques. Este período é conhecido como o reform park ou playground period. São dois principais fatores de mudanças: playgrounds e espaços locais para a população. Estes parques são espaços menores por serem mais próximos a áreas residenciais e industriais; são ocupados com caixas de areias para brinquedos, exercícios físicos e cursos de higiene, saúde, profissionalização e naturalização americana para imigrantes (MAGNOLI, 2006).

Entre 1930 e 1965, os Estados Unidos vive um período de recreation facility. A recreação é foco político do período e assegurado para todos os segmentos da população. Aplica-se a execução e implantação seriada de inúmeras áreas de lazer, onde os parques são os principais atrativos deste cenário (MAGNOLI, 2006). 
Os parques ao longo das décadas foram modelados e projetados de acordo com as aspirações e necessidades da sociedade. Nas palavras de Magnóli (2006):

[...] a configuração, a conformação na história dos parques reflete, mais do que se quer pensar, intenções sociais imediatas em uma atitude e filosofia subjacente em relação ao fenômeno urbano. Os modelos em sua sequência, vão se sobrepondo por partes em espaço e em tempo nem sempre transparentes em diferentes contextos e diferentes populações (MAGNOLI, 2006, p. 209).

\subsubsection{Os parques urbanos na atualidade}

Os parques urbanos são espaços públicos com área geograficamente delimitada, com dimensões espaciais representativas e a predominância de vegetação de porte arbóreoarbustivo. Apresenta funções estéticas, ecológicas e sociais, e são considerados como a principal área de lazer e recreação da população citadina (KLIASS, 1993; SOLECKI; WECH, 1995; SORENSEN et al., 1998; OLIVEIRA, 2007).

De acordo com Whately et al. (2008), esta concepção denota uma preocupação pela administração pública em harmonizar os diversos usos demandados aos parques, assim como uma necessidade de regrar estes usos, defini-los e pactuar com os usuários.

O principal uso destas áreas destinam-se as atividades humanas de recreação, sendo esta a principal distinção entre um parque urbano e um parque categorizado como Unidade de Conservação (UC) de acordo com o Sistema Nacional de Unidades de Conservação - SNUC (BRASIL, 2000). Oliveira (2007) e Oliveira e Bitar (2009) citam que, enquanto os Parques Urbanos são construídos para atender as necessidades de lazer e recreação, os parques categorizados de UC têm como objetivo principal a preservação dos recursos naturais e da biodiversidade in situ.

Os parques urbanos possuem instalações de lazer e recreação para atender a função de uso público. Os parques integrantes do SNUC (Sistema Nacional de Unidades de Conservação) (BRASIL, 2000) têm como foco principal o desenvolvimento de atividades de pesquisa, educação ambiental e turismo ecológico; estas práticas estão sujeitas à deliberação prévia do órgão competente e às normas e restrições estabelecidas no plano de manejo da unidade (OLIVEIRA, 2007).

O parque da cidade contemporânea tem o papel de amenizar potenciais problemas, podendo assumir função similar ao parque categorizado como Unidade de Conservação (UC). Este fator é evidenciado em parques urbanos que visam proteger áreas frágeis (encostas e 
fundos de vale) e conservar fragmentos florestais; estes "novos" parques comumente são denominados por "Parques Ecológicos", mas seus usos são diferentes do parque ecológico categorizado como uma UC do SNUC. Macedo e Sakata (2003) destacam que o modelo de parque que conhecemos hoje é um elemento típico da grande cidade o qual se apresenta em constante processo de recodificação.

O parque ecológico objetiva prioritariamente a conservação desse ou daquele recurso ambiental, como um banhado ou um bosque. E, paralelamente possui áreas muito concentradas, voltadas para atividade de lazer ativo - com jogos e recreação infantil, ao lado de áreas voltadas para o lazer passivo - como caminhadas por trilhas bucólicas e esparsas (MACEDO; SAKATA, 2003, p.13).

Segundo Costa (2011), os parques urbanos são sinônimos de qualidade de vida e até mesmo de status; podem ser considerados, o lócus da interação entre a urbanização e os recursos naturais dentro das grandes cidades, e estão intrínsecos à lógica de conflitos que as caracterizam, necessitando de especial atenção quanto a sua gestão.

Para Kliass (1993), um bom e efetivo planejamento pode aproveitar as potencialidades paisagísticas do sitio urbano, fazendo-se necessário o estabelecimento prévio de reservas de áreas verdes para suprir as futuras demandas por parques urbanos.

Os parques devem satisfazer as funções de lazer, ecológica e estética:

- Função de lazer - aquelas que satisfazem as necessidades de lazer; sejam elas físicas, psicológicas ou sociais (ALVAREZ, 2004);

- Função ecológica - aquela que melhora a qualidade ambiental com relação ao clima, à preservação e a proteção dos recursos hídricos, geomorfológicos, pedológicos, florísticos e faunísticos (ALVAREZ, 2004);

- Função estética: aquela que modela a estrutura urbana, integrando usos conflitantes, ocultando espaços indesejáveis, enfeitando cenários culturais e diversificando espaços (ALVAREZ, 2004).

Para cumprir tais funções os parques são constituídos por aspectos de ordem material (quantidade de bancos, quadras, áreas para piquenique, sanitários), elementos naturais (vegetação, lagos, contato das pessoas com os animais, condições climáticas) e ainda por parâmetros de ordem imaterial (controles, sensações, emoções, conflitos, imaginários e identidades de grupo) (NUNES JÚNIOR, 2011).

O Quadro 1, elaborado por Matos, Lopes e Vitorino (2005) apresenta as funções estratégicas que um parque urbano pode desempenhar na melhoria do ambiente urbano e na 
qualidade de vida das populações citadinas.

Quadro 1- Funções estratégicas dos parques Urbanos.

\begin{tabular}{|c|c|}
\hline ASPECTOS & FUNÇÕES \\
\hline Gerais & $\begin{array}{c}\text { Estruturantes do espaço público: } \\
\qquad \text { Culturais } \\
\bullet \text { Integração } \\
\bullet \text { Enquadramento }\end{array}$ \\
\hline Gerais & $\begin{array}{l}\text { - Didáticas } \\
\text { - Jogo } \\
\text { • Lazer } \\
\text { - Recreação }\end{array}$ \\
\hline De concepção & $\begin{array}{c}\text { • Melhorias ecológicas } \\
\text { • melhorias micro-climáticas } \\
\text { • melhorias quanto à poluição local }\end{array}$ \\
\hline De localização & $\begin{array}{c}\text { Proteção e valorização dos recursos naturais locais } \\
\qquad \begin{array}{c}\bullet \text { água } \\
\bullet \text { solos } \\
\bullet \text { radiação solar }\end{array}\end{array}$ \\
\hline
\end{tabular}

Whately (2008) ao realizar pesquisa sobre as aspirações dos usuários em parques urbanos na cidade de São Paulo hierarquizou a busca pelos seguintes usos: atividades físicas, lazer ou cultura; descanso e relaxamento e atividades promovidas pelo parque (TABELA 1).

Tabela 1 - Relação entre os atrativos oferecidos em Parques Urbanos e a busca pelos usuários em valores percentuais $(\%)$.

\begin{tabular}{cc}
\hline Uso & $(\boldsymbol{\%})$ \\
\hline Atividades físicas & 68 \\
Lazer ou cultura & 35 \\
Descanso e relaxamento & 17 \\
Atividades promovidas pelo parque & 10
\end{tabular}

Fonte: Adaptado de Whately (2008).

Os dados apresentados por Whately (2008) permitem evidenciar que: para que o parque cumpra com a sua função social faz-se necessário equipamentos para práticas esportivas e recreacionais.

A contribuição para melhoria da qualidade de vida e urbana pode não ser assegurada devido à carência de parques na cidade e principalmente a gestão. De acordo com Philippi 
Júnior e Rodrigues (2006), na cidade de São Paulo estes espaços apresentam excesso de visitação, criando um ambiente ruidoso e estressante, às vezes quase tão desagradável quanto os congestionamentos de trânsito dos quais os visitantes buscam escapar ao visitar um parque. Ao invés de encontrar tranquilidade e contato com a natureza, o visitante encontra barulho, poluição, trânsito, violência, todos aqueles malefícios da grande metrópole que eles procuram esquecer ao entrar em contato com a área verde.

Para evitar que tais fatores ocorram, fazem-se necessários que tais espaços sejam bem distribuídos na cidade (quantidade) e sejam gerenciados de acordo com as aptidões e necessidades de cada parque (qualidade).

\subsubsection{Classificação dos parques urbanos}

A literatura referente à classificação e tipologias de parques urbanos é incipiente e ambígua; diferentes autores conceituam distintamente parques urbanos destinados ao mesmo tipo de uso.

Para Mantovani (2005) os parques urbanos podem ser distintos em três tipos mais relevantes:

- Parque Tecnológico: têm apenas mobiliários de uso público, áreas de lazer amplas e não têm elementos naturais que os marque; são pequenos em termos de áreas e existem alguns que não usam elementos biológicos quaisquer.

- Parques Jardins: os elementos biológicos têm funções importantes e são mantidos sob manejo contínuo, de forma que estão sempre sendo alterados e manejados, principalmente com cortes e podas. Nossos parques jardins, quando implantados, têm uma predominância marcada de espécies exóticas, já que raramente são utilizadas espécies nativas, principalmente herbáceas e arbustivas.

- Parques Ecológicos: os ecossistemas naturais são conservados em toda a sua estrutura, exercendo suas funções naturais no sentido pleno que a vegetação tem.

Bonduki e Ferreira (2006) apresentam a seguintes tipologias:

- Parques Nucleares Intraurbanos: correspondem à área verde inserida na malha urbana; têm por objetivo promover atividades de lazer em ambientes predominantemente vegetados e com superfície permeável. Constituem núcleos bem 
delimitados em termos espaciais e de gestão. Podem ser classificados em Parques de Vizinhança, Parques de Bairro e Parques Regionais. Esta classificação é determinada segundo as dimensões físicas da área.

- Parques da Cidade: são parques que possuem equipamentos sócio-esportivoculturais; áreas para grandes eventos; campos relvados; áreas para piquenique; equipamentos de ginástica; equipamentos de recreação; estufas; viveiros; áreas de estar com bancos, mesas; passeios para pedestres; ciclovia; área para jogos informais; quadras poli esportivas; administração; sanitários e outros.

Os autores supramencionados (BONDUKI; FERREIRA, 2006) ainda citam a tipologia denominada de Parque Linear, que corresponderia ao Parque Ecológico descrito por Mantovani (2005). Entretanto, esta tipologia restringe-se às áreas lindeiras aos cursos hídricos.

Segundo Bonduki e Ferreira (2006), Parque Linear da rede Hídrica corresponde à área verde associada à rede hídrica, podendo em função das características dos espaços que atravessa ser composto por: $i$ ) Área Core, coincidente com a Área de Preservação Permanente, definida pela legislação em vigor; ii) Zona de Amortecimento, como área de transição entre a Área Core e a Zona Equipada; e iii) Zona Equipada, para o provimento de equipamentos de lazer.

Esta tipologia de parque consiste em uma zona de proteção ambiental a qual tem por objetivos proteger ou recuperar os sistemas lindeiros aos cursos d'água, conservar a vegetação ciliar, conectar áreas verdes e espaços livres de um modo geral, controlar enchentes e prover áreas verdes para o lazer (BONDUKI; FERREIRA, 2006; MARTINS JÚNIOR, 2007).

Nota-se que na classificação descrita por Mantovani (2005), a tipologia dos parques é dada de acordo com as características físicas e ecológicas do ambiente; já na tipologia proposta por Bonduki e Ferreira (2006) os parques assumem sua denominação de acordo com a localização na malha urbana e o uso.

Lira (2001) apresenta uma classificação sintética dos parques urbanos de acordo com seu uso:

- Parques de Preservação Ambiental, para as Unidades Conservação enquadradas no SNUC (BRASIL, 2000);

- Parques Especiais, jardins botânicos, zoológicos, viveiros;

- Parques de Recreação destinados ao uso público para lazer; 
- Parques de Vizinhança, recreação infantil;

- Parques de Bairro, áreas de tamanho médio com aparelhos de recreação; e

- Parques Setoriais/Metropolitanos, grandes áreas vegetadas, dotadas de equipamentos para recreação e lazer.

Kliass e Magnoli (2006) apresentam a seguinte classificação para parques urbanos na cidade de São Paulo:

- Parque de Vizinhança - áreas verdes destinadas à recreação para crianças de 0 a 10 anos; seu raio máximo de atendimento é de 500 metros, sem travessia de ruas de trânsito;

- Parque de bairro - destinado à recreação de jovens de 11 a 24 anos; seu raio máximo de atendimento é de 1000 metros;

- Parque setorial - área destinada para a recreação de toda a população do município, com equipamentos para utilização aos finais de semana, com um raio de atendimento máximo de 5000 metros; e

- Parques metropolitanos - áreas destinadas à recreação de toda a região metropolitana, localizados nas reservas florestais, junto a represas e/ou outros elementos naturais marcantes.

Whately (2008) classifica os parques de acordo com suas funções preponderantes:

- Naturais - parques que permitem a integridade dos sistemas naturais, como recursos hídricos e vegetação, além de apresentar potencial de recuperação e manutenção;

- Históricos - apresentam elementos históricos como museus e patrimônios tombados;

- Lazer - espaços cujos maiores atrativos são os equipamentos para recreação e lazer. Áreas com baixa ou nula integridade dos recursos naturais, cuja vegetação foi implantada;

- Lineares - apresenta configuração longilínea e extensiva ao longo da rede hídrica.

Independentemente da nomenclatura que o parque receba, o importante é que este cumpra com o seu propósito inicial.

Para fins desta pesquisa adotou-se a classificação proposta por Mantovani (2005), uma vez que tal classificação contempla os aspectos conservacionistas de um parque em sua forma mais ampla. 


\subsubsection{Estado da arte: estudos sobre parques urbanos no cenário brasileiro}

Comumente os estudos referentes a parques urbanos estão focados na análise de vegetação e/ou fauna (SOUZA, 2011; NASCIMENTO, 2005; BIONDI; MULLER, 2013), ou ora na análise da percepção ambiental e utilização de seus usuários (REIS, 2001; SILVA, 2003; TEIXEIRA, 2007; CORADINI, 2008; ALVES; RAIMUNDO, 2009).

São raros estudos focados em proposições metodológicas para análise. Cabe ressaltar alguns estudos:

Holmes (2008) desenvolveu indicadores de risco ecológico com base no modelo Pressão-Estado-Impacto-Resposta (PEIR) com o intuito de fomentar a gestão de parques urbanos. Os indicadores desenvolvidos foram: área com solo impermeabilizado, área com solo erodido, área com solo contaminado e qualidade das águas superficiais. Tais indicadores foram testados em parques no Distrito Federal.

Costa (2011) teve por objetivo a discussão e avaliação da gestão dos parques urbanos localizados no Distrito Federal, buscando descrever e avaliar os aspectos normativos, institucionais e administrativos que compõem a lógica da gestão dos parques urbanos. Sua pesquisa conclui que é indispensável para a gestão dos parques a existência de plano de manejo traçado; o enquadramento do parque em uma nomenclatura adequada; registro cartorial; a definição e publicação de suas poligonais; a existência de seu ato legal de criação que considere o estudo prévio do local para sua instalação e a previsão de infraestrutura, bem como o reconhecimento da posse e existência e fidedignidade da documentação.

Oliveira (2007) propõe um sistema de indicadores para o monitoramento de parques urbanos que fornece informações sobre seu status no cumprimento dos seus objetivos, utilizando a técnica de indicadores pressão-estado resposta, sob uma ótica cartesiana, onde os elementos analisados são interpretados individualmente e não apresentam uma resposta do parque como um todo. Sua técnica é aplicada em três parques na cidade de São Paulo.

Castelnou Neto (2006) faz um estudo crítico analítico sobre a perda das utopias ecológicas dos parques curitibano. Segundo o referido autor os parques são objetos de consumo da população e publicidade da gestão pública. Assim, constatam-se os fenômenos de "espetacularização" e de "mercantilização" dos parques.

Friederich (2007) desenvolve um estudo centrado na discussão sobre o desenvolvimento de Parques Lineares em fundos de vale. Seu foco consiste na compatibilidade de aspectos conservacionistas no que tange as questões ambientais e de promoção de uso público destas áreas. Para tanto a autora dedica-se a um estudo de caso em um Parque Municipal situado em 
Campo Bom (RS). Conclui que faltam critérios biofísicos, sociais e econômicos no planejamento, projeto e gestão dos parques lineares em áreas de fundo de vale urbanas, fator que infere no desempenho e sustentabilidade da área.

Buccheri Filho (2012) apresenta uma discussão sobre a implementação dos parques na cidade de Curitiba, onde questiona se o planejamento destes espaços foi baseado em um modelo sistemático ou oportunista. Conclui que o planejamento se deu de forma oportunista, por tirar proveito de situações já encontradas no espaço, ao invés de servir aos cidadãos para lazer em primeiro lugar, tendo interesses primários derivados de outras questões como melhor aproveitamento do uso da terra.

Moura et al. (2012) desenvolveram uma adaptação da metodologia DRP (Diagnóstico Rural Participativo) para parques municipais, com o intuito de permitir que grupos ligados ao parque, gestão e população do entorno, pudessem refletir sobre problemas por eles identificados, partilhar experiências, soluções e mediar à comunicação entre os grupos participantes. Os referidos autores realizam o experimento, no Parque Municipal Fazenda Lagoa do Nado, em Belo Horizonte (MG). Concluem que a técnica é eficiente para avaliar as relações população-parque, identificar problemas e soluções para melhorar a comunicação entre ambos, intercambiar relações e ideias entre gestores e comunidade, além de proporcionar soluções para a gestão.

Ressalta-se que não é de interesse realizar nenhum tipo de julgamento quanto ao procedimento adotado, mas sim, destacar para o leitor, as características das técnicas utilizadas.

Como verificado, a análise destes espaços tendem a serem cartesianas e a adaptar modelos pré-existentes; ao que tange a questão de monitoramento, o principal sistema utilizado é o Pressão-Estado-Resposta. Não é de interesse realizar uma análise crítica entre as ferramentas existentes, mas ressalta-se a necessidade de comunicação entre análises com caráter ecológico e análises com caráter social.

\subsection{O FUNDO DE VALE COMO ÁREA ESTRATÉGICA PARA CONSERVAÇÃO DA NATUREZA NA CIDADE}

É evidente a necessidade de se incrementar espaços verdes e de conservação nas cidades. Visando uma composição paisagística mais harmônica, alguns ambientes apresentam prioridade de conservação, tais como as encostas e os fundos de vale. 
Segundo Ross (1994) estes ambientes apresentam fragilidade potencial, ou seja, fragilidades correlacionadas às condições naturais do relevo e solos, tais como inundações periódicas (fundo de vale) e deslizamentos (encosta).

Os referidos ambientes, quando submetidos a perturbações e ao uso intensivo da terra fragilidade emergente (ROSS, 1994) -, podem agravar os processos naturais e desencadear danos à saúde pública e ao poder público.

Para fins desta pesquisa têm-se como foco de análise os parques urbanos localizados nos fundos de vale, visto que este ambiente apresenta-se como área estratégica para a conservação no ambiente citadino.

Os fundos de vale são as áreas de menores cotas de um terreno, para onde escoam as águas pluviais; cortadas ou não por cursos d'água perenes (PINHO, 1999; AMORIM, 2004).

Para Cunha e Guerra (2000, p. 361), “O vale fluvial é uma depressão alongada (longitudinal) constituída por um ou mais talvegues e duas vertentes com sistemas de declive convergente"; estas áreas também são denominadas de planície de inundação e várzea.

A planície de inundação exerce fundamental importância no controle do regime hídrico de uma bacia por concentrar o escoamento superficial e subsuperfícial (TRENTIN; SIMON, 2009). Estas áreas recebem o escoamento excedente, derivado de picos pluviométricos, tornando-se parte do leito do rio durante as cheias (TRENTIN; SIMON, 2009; CHRISTOFOLETTI, 1974). Este fator permite que o fundo de vale caracterize-se como uma área estratégica para a conservação, com o intuito de assegurar equilíbrio na bacia hidrográfica, por escoar os picos de maior vazão e sedimentos.

A planície de inundação também conhecida como várzea constitui a forma mais comum de sedimentação fluvial encontrada nos rios de todas as grandezas. A designação é apropriada porque nas enchentes toda essa área é inundada, tornando-se o leito do rio. (CHRISTOFOLETTI, 1980, p.75). Esta planície é formada pelas aluviões e por materiais variados depositados no canal fluvial ou fora dele, na vazante. O escoamento restringe-se a parcelas do canal fluvial, onde há deposição de partes da carga detrítica com o progressivo abaixamento do nível das águas. Ao contrário, com as cheias, há elevação do nível das águas que, muitas vezes, transbordando por sobre as margens inundam as áreas baixas marginais (CHRISTOFOLETTI, 1980).

Os canais fluviais existentes nos fundos de vale podem ser classificados em: $i$ ) meandrante; ii) anastomatado; iii) reto; iv) deltaico; v) ramificado; vi) reticulado e vii) irregular (CHRISTOFOLETTI, 1980).

Os canais anastomosados são os formados em condições especiais altamente 
relacionadas com a carga sedimentar do leito. Quando o rio transporta material grosseiro em grandes quantidades e não tem potência suficiente para conduzi-lo até o seu nível de base final, deposita-o no próprio leito. O obstáculo natural que então se forma, permite que o rio se ramifique em múltiplos canais pequenos e rasos e desordenados devido às constantes migrações entre ilhotas; os trechos anastomosados sempre se localizam ao longo do curso fluvial, pois no ponto de início e no ponto terminal deverá haver um único canal (CHRISTOFOLETTI, 1980).

A padronagem reticulada se assemelha à disposição anastomasada, mas é caracterizada pelo escoamento efêmero e pela subdivisão em várias embocaduras que se perdem na baixada ou em lagos temporários; a padronagem deltaica caracteriza-se pela ramificação do curso fluvial inicial, subdividindo-se em vários distributários que alcançam o mar, lago ou outro rio; diferencia-se do anastomosado e reticulado por causa do escoamento perene e maior estabilidade dos canais de escoamento (CHRISTOFOLETTI, 1980).

Os canais retos são aqueles que percorrem um trajeto retilíneo sem se desviar de sua trajetória normal em direção à foz. Os canais verdadeiramente retos são muito raros na natureza, existindo principalmente quando o rio está controlado por linhas tectônicas, como no caso de cursos de água acompanhando linhas de falha (CHRISTOFOLETTI, 1980).

O canal ramificado surge quando existe um braço de rio que volta ao leito principal formando uma ilha. Os canais meândricos são aqueles em que os rios descrevem curvas sinuosas, largas, harmoniosas e semelhantes entre si, através do trabalho contínuo de escavação na margem côncava (ponto de maior velocidade da corrente) e de deposição na margem convexa (ponto de menor velocidade) (CHRISTOFOLETTI, 1980).

Existe uma série completa de padrões intermediários entre os canais retos e os canais efetivamente meândricos. É possível distinguir outra categoria de canais intermediários entre os retos e os que são totalmente irregulares em sua disposição espacial (CHRISTOFOLETTI, 1980).

As atividades humanas podem alterar toda a dinâmica e a forma dos canais. Em função das alterações da quantidade de água infiltrada e de sua circulação promovidas pelas intervenções antropogênicas na superfície do relevo, os cursos d'água passam a receber mais rapidamente e de forma mais intensa as enxurradas, que promovem a erosão das margens, inundações nas várzeas e o assoreamento dos canais (CANIL, 2006).

De acordo com Hengeveld e De Vocht (1982), as águas foram o principal fator de desenvolvimento humano. As civilizações instalaram-se as margens hídricas e rapidamente a água tornou-se o centro das preocupações humanas, necessitando do desenvolvimento de 
tecnologias para a contenção de inundações.

Para solucionar problemas relacionados às inundações, as administrações públicas canalizam e/ou retificam os cursos d'água que atravessam seus municípios. Comumente o local do antigo leito do rio e/ou as margens são utilizados para a implantação de sistemas viários. Com isso além de não se importarem com o que vai acontecer a montante dessa obra, não se dão conta que estarão agravando o fenômeno ilha de calor, que intensificará a pluviosidade, que, por sua vez, poderá causar novas inundações (CAVALHEIRO, 1995).

As alterações nos cursos dos canais hídricos são realizadas não só para solucionar potenciais problemas relacionados a enchentes, mas, também para "acomodar" o rio a essa nova paisagem edificada.

Oliveira, Reckziegel e Robaina (2006), propõem a seguinte classificação para os canais hídricos na paisagem urbana: i) Canais Abertos: são os canais de drenagem que escoam abertamente pela área urbana, com intervenções nas margens e no leito; ii) Canais Fechados: são os canais que percorrem a área urbana, e que se encontram completamente fechados por galerias de concreto; iii) Canais Mistos: são os canais em que alguns trechos encontram-se abertos, outros com algum tipo de proteção nas margens ou completamente fechados por galerias setorizadas; iv) Canal Retificado: são os trechos dos canais de drenagem onde a intervenção ocorreu através da diminuição da sinuosidade do canal; v) Barramentos: são todas aquelas obras realizadas nos canais de drenagem que barram a passagem da água quando há um aumento da vazão. Geralmente os barramentos estão associados às vias perpendiculares ao canal e suas respectivas tubulações.

As obras de canalização e retificação têm por objetivo aumentar a velocidade e vazão dos rios, com o intuito de promover o escoamento rápido do grande volume de água que atinge os canais pluviais e possibilitar a ocupação de suas margens. A primeira meta muitas vezes fica comprometida pela retirada da vegetação marginal, pelo assoreamento do leito, e principalmente, pela ocupação das áreas de retenção natural das águas, como as planícies de inundação. Tais áreas deveriam ser sempre destinadas à preservação ou conservação, com presença de cobertura vegetal, possibilitando a infiltração e/ou permanência de água (BOTELHO; SILVA, 2004).

A manipulação direta do rio ou mesmo de sistemas hidrográficos inteiros, representam o mais profundo impacto humano que pode ser ocasionado ao ciclo hidrológico. A intervenção humana em sistemas hidrográficos relaciona-se comumente aos seguintes motivos: regularização da descarga, armazenagem de água, aumento do fluxo total, extração de água ou alteração do canal dos rios. O Quadro 2 apresenta as principais técnicas de controle de rios e 
seus principais efeitos (DREW, 2011).

Quadro 2- Antropização de rios: técnicas e efeitos nos cursos hídricos.

\begin{tabular}{|c|c|c|}
\hline Tipo de controle & Técnica & Efeitos subsidiários e realimentadores \\
\hline \multirow[b]{2}{*}{$\begin{array}{l}\text { Regularização da } \\
\text { descarga }\end{array}$} & Reservatórios das cabeceiras & Novo ambiente aquático (lago) - ecologia \\
\hline & Comportas & $\begin{array}{c}\text { Aumento a sedimentação } \\
\text { Migração da ictiofauna interrompida } \\
\text { Aumento da evaporação, novo microclima local }\end{array}$ \\
\hline \multirow[b]{2}{*}{$\begin{array}{l}\text { Armazenagem de } \\
\text { água }\end{array}$} & Reservatórios de acumulação & Novo ambiente aquático (lago) - ecologia \\
\hline & Acumulação em estuários & $\begin{array}{l}\text { Alteração do ambiente estuarino, sobretudo via } \\
\text { sedimentação, destruição das terras úmidas do estuário } \\
\text { Alteração da deposição, erosão e correntes }\end{array}$ \\
\hline \multirow{3}{*}{$\begin{array}{l}\text { Aumento do } \\
\text { fluxo }\end{array}$} & Entrada de água subterrânea & Abaixamento dos níveis de água subterrânea \\
\hline & Transferência interbacia & Mistura de águas quimicamente diferentes \\
\hline & Controle do escoamento da bacia & Alteração da geomorfologia fluvial \\
\hline \multirow{3}{*}{$\begin{array}{l}\text { Diminuição do } \\
\text { fluxo }\end{array}$} & Recarga artificial & Mistura de águas quimicamente diferentes \\
\hline & Transferência interbacia & Elevação dos níveis de água subterrânea \\
\hline & Controle do escoamento da bacia & Alteração da geomorfologia fluvial \\
\hline \multirow{3}{*}{$\begin{array}{l}\text { Alteração do } \\
\text { canal }\end{array}$} & Aprofundamento, alargamento, & Alteração das velocidades, com erosão e sedimento \\
\hline & $\begin{array}{l}\text { Retinilização } \\
\text { Concretagem }\end{array}$ & $\begin{array}{l}\text { Impede a troca de água entre margens e rios e vice- } \\
\text { versa }\end{array}$ \\
\hline & Desvios & $\begin{array}{l}\text { Altera a hidrologia do solo e, assim o escoamento } \\
\text { para o rio }\end{array}$ \\
\hline
\end{tabular}

Fonte: DREW, 2011.

Em resposta às perturbações na geometria do canal ocorrem mudanças na vazão e fornecimento de sedimentos. Quando aumenta a vazão, consequentemente aumenta a velocidade da água e a profundidade do canal, ocasionando atrito na carga de sedimentos no leito maior. Inversamente, o leito maior é preenchido com sedimentos à medida que a descarga diminui. Estas alterações referem-se respectivamente a sedimentação e assoreamento do canal, as quais se associam as alterações no uso da terra. A sedimentação inicia-se no momento do desmatamento do solo para a agricultura, os picos se dão anos mais tarde com a entrada de sedimentos trazidos pela atividade de construção suburbana. A urbanização continua e o solo é pavimentado e edificado, aumentando a sedimentação e o escoamento das águas superficiais, resultando na degradação do canal (FIGURA 1); tais condições se manifestam não só pela ausência dos montantes típicos de sedimentos do canal, mas também pela severa erosão do canal, que ocorreu anteriormente a urbanização (MARSH, 2005). 


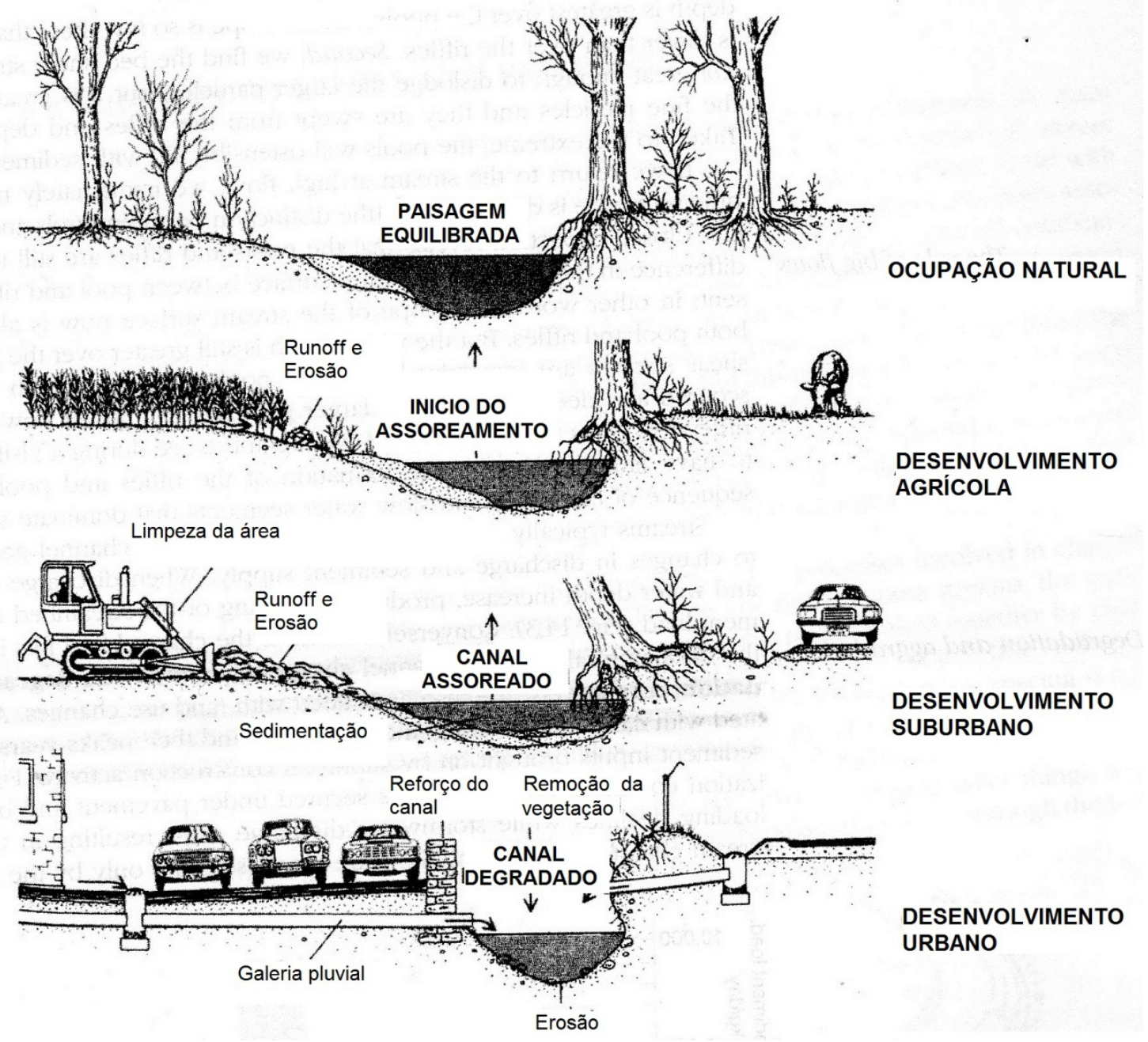

Figura 1 - Vista parcial do processo de degradação do fundo de vale: início com as atividades agrícolas, urbanização e urbanização intensa.

Fonte: MARSH, 2005.

Os rios nas áreas urbanas geralmente possuem baixo teor de oxigênio dissolvido, estando fortemente poluídos com sedimentos e materiais em suspensão, comumente são eutróficos. Somente um reduzido espectro de vida aquática consegue tolerar este ambiente (DREW, 2011).

\subsubsection{Vegetação ciliar como ferramenta na conservação}

Considerando os fundos de vale como áreas suscetíveis à degradação no ambiente urbano, a vegetação exerce papel fundamental na conservação ao minimizar as perturbações entre o meio degradado e o corpo hídrico. Sua manutenção e conservação são necessárias para manter as funções da paisagem, tais como habitat para fauna, estabilidade física das margens, 
área de infiltração das águas pluviais, redução no escoamento superficial, entre outras.

As florestas que ocorrem ao longo dos cursos d’água e no entorno de lagos e de nascentes recebem as denominações de matas ciliares, ripárias, ribeirinhas ou de galeria (BOTELHO; DAVIDE, 2002). Estes ambientes não se enquadram nas tipologias de Unidades de Conservação previstas no SNUC, pois respondem a uma dinâmica de gestão diferente e foram instituídas por outro instrumento legal, o Código Florestal de 1965 (MEDEIROS; IRVING; GARAY, 2004).

A integridade ecológica destas áreas permite o equilíbrio na deposição de sedimentos e nutrientes entre outros materiais oriundos de áreas mais íngremes, possibilita a infiltração de água no solo, minimiza o escoamento superficial, processos erosivos, entre outros (BINFORD; BUCHENAU, 1993).

A cobertura vegetal aumenta a estabilidade da superfície, criando e mantendo a estrutura da camada superficial do solo. Regula o sistema físico-climático, os ciclos biogeoquímicos e os processos hidrodinâmicos (de superfície e subsuperfície). Seu papel principal é promover a redução do impacto das gotas de chuva na superfície do solo (por meio de estrato arbóreo e serapilheira), a força do atrito diminui a energia do escoamento superficial (CANIL, 2006).

O desmatamento contribui para o aumento do impacto da chuva na superfície do solo. A diminuição do atrito na superfície favorece a ação do escoamento superficial e transporte de materiais. A redução do conteúdo de matéria orgânica e a desagregação de partículas caracterizam a erodibilidade do solo (CANIL, 2006).

Sem a proteção das plantas, o solo fica sujeito a processos erosivos pelo vento (erosão eólica) e pela água (erosão hídrica), sendo esta ultima considerada a mais importante no Brasil. O material retirado do solo pela erosão hídrica é constituído principalmente por matéria orgânica e partículas finas, com predominância da argila. Esse material constitui a parte ativa do solo, a qual retém nutrientes que são fornecidos às plantas. Portanto, o prejuízo que fica mais aparente é a perda da fertilidade do solo, além do dano ocasionado ao próprio solo; o material transportado atinge leitos de rios e lagos, provocando assoreamento e contribuindo para as inundações (PAREIRA, 1997).

Estes fatores tornam a vegetação ripária de suma importância para a proteção de ambientes de fundo de vale. A vegetação ripária funciona como um sistema tampão, o qual minimiza potenciais impactos entre a transição do sistema terrestre para o aquático, como o transporte de sedimentos e nutrientes do solo de áreas adjacentes, que podem ocasionar excesso de material orgânico no corpo d'água e por consequência eutrofização e/ou 
assoreamento ocasionando a mortalidade da comunidade aquática (PADILHA, 2009; LOWRENCE et al., 1997). A função tampão da vegetação ciliar (FIGURA 2) pode ser divida em zonas de acordo com as principais funções: Zona 3 - na qual existem plantas herbáceas permitindo o escoamento superficial e subsuperfícial; Zona 2 - consiste na zona de floresta manejada, na qual se dá a transição entre a área de herbáceas e arbóreas, onde ocorre pouco escoamento superficial e infiltração; e a Zona 1 - que consiste na zona de floresta intacta, onde a interação de água e solo se da por infiltração. Este seria o ambiente ideal para manter a estabilidade do rio (LOWRENCE et al., 1997).

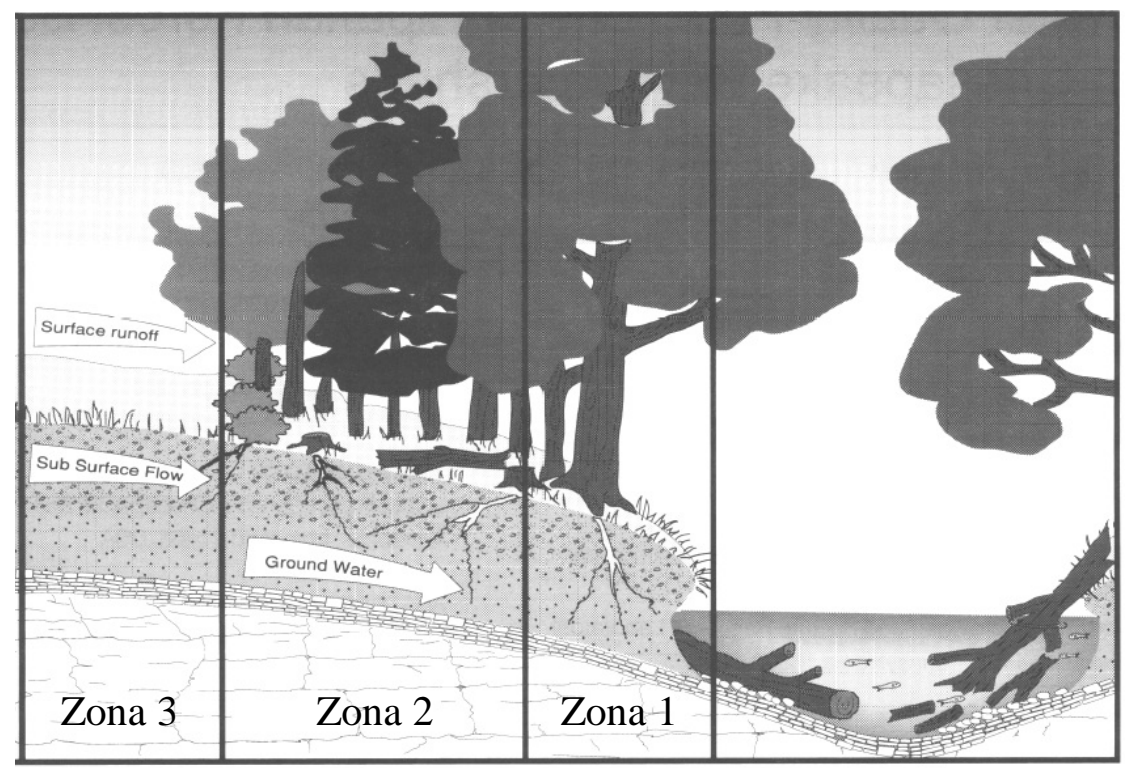

Figura 2 - Representação gráfica das zonas tampão das florestas ripárias. Fonte: LOWRENCE et al., 1997.

O Código Florestal brasileiro (BRASIL, 2012) resguarda a proteção dessas áreas assegurando a presença de vegetação ao longo das faixas marginais dos rios, da seguinte forma (Lei 12.651/2012 - Artigo $4^{\circ}$ ):

i) 30 (trinta) metros para os cursos d'água de menos de 10 (dez) metros de largura;

ii) 50 (cinquenta) metros para os cursos d'água que tenham de 10 (dez) a 50 (cinquenta) metros de largura;

iii) 100 (cem) metros para os cursos d'água que tenham de 50 (cinquenta) a 200 (duzentos) metros de largura;

iv) 200 (duzentos) metros para os cursos d'água que tenham de 200 (duzentos) a 600 (seiscentos) metros de largura;

v) 500 (quinhentos) metros para os cursos d'água que tenham largura superior a 600 (seiscentos) metros e; 
vi) um raio de 50 (cinquenta) metros de largura nas nascentes e olhos d'água.

vii) as áreas no entorno dos lagos e lagoas naturais, em faixa com largura mínima de: a) 100 (cem) metros, em zonas rurais, exceto para o corpo d'água com até 20 (vinte) hectares de superfície, cuja faixa marginal será de 50 (cinquenta) metros; b) 30 (trinta) metros, em zonas urbanas.

\subsection{ANÁLISE E MONITORAMENTO DE PAISAGENS}

A análise da paisagem é uma ferramenta que contribui para a melhoria da qualidade ambiental e indica a necessidade de possíveis mudanças nos espaços urbanos, especialmente quando estes podem colocar em risco a saúde e o bem estar humano devido à exposição diária aos altos níveis de artificialidades presentes nas grandes cidades (PEREIRA, SILVA E VEIGA, 2011).

Fazem-se necessários estudos pontuais da paisagem com visão integradora com o intuito de fomentar intervenções planejadas. Assim, a análise paisagística necessita de um conjunto de métodos e procedimentos técnico-analíticos que permitam conhecer e explicar a estrutura da paisagem, estudar suas propriedades, índices e parâmetros sobre a dinâmica, a história do desenvolvimento, os estados, os processos de formação e transformação da paisagem e a pesquisa das paisagens naturais, como sistemas manejáveis e administráveis (RODRIGUEZ; SILVA; CAVALCANTI, 2007).

Para garantir a qualidade de vida e ambiental, mitigar os problemas entre antropização e meio natural, e identificar de maneira clara a atuação de cada um dos agentes urbanos que interagem na composição dos espaços, paisagens, territórios e mais especificamente, dos parques urbanos, é necessário que haja embasamento em informações fidedignas, alcançadas por avaliações e monitoramentos contínuos (COSTA, 2011).

Avaliação significa mensurar de forma sistemática - sobre uma base continuada de tempo - os resultados obtidos e comparar esses resultados com o que foi planejado, para elevar a eficiência e a produtividade da unidade em análise. Os indicadores assumem então papel fundamental, pois apenas com a qualificação e quantificação das grandezas contidas nos objetivos por meio da formulação de indicadores é que se torna possível a medição (BROSE, 2004).

A monitoria se diferencia qualitativamente de um simples acompanhamento, pois além de documentar sistematicamente o processo de implantação do Plano, identifica os desvios na 
execução das atividades propostas, fornecendo as ferramentas para a avaliação. A avaliação possibilita as ações corretivas para ajuste ou replanejamento das atividades (GALANTE; BESERRA; MENEZES, 2002).

Monitoramento consiste no acompanhamento contínuo por parte de gestores e gerentes, do desenvolvimento dos programas e políticas em relação a seus objetivos e metas. Deve ser capaz de prover informações sobre o programa para seus gestores, permitindo a adoção de medidas corretivas para melhorar sua operacionalização. É realizado por meio de indicadores (VAITSMAN; RODRIGUES; PAES-SOUSA, 2003).

Construir um bom sistema de monitoramento e avaliação depende das condições dadas. Um sistema pode funcionar para um projeto, e não funcionar para outro. Conhecer o que outros fizeram e aprenderam em condições semelhantes leva a alguns esclarecimentos sobre o assunto e evita possíveis erros (ARCHER et al., 2004).

Silva (2004) ao desenvolver um sistema de monitoramento participativo das práticas ambientais sustentáveis do "projeto Doces Matas na Comunidade do Sossego, Simonésia, Minas Gerais", relata sete etapas (FIGURA 3), com o intuito de simplificar a análise.

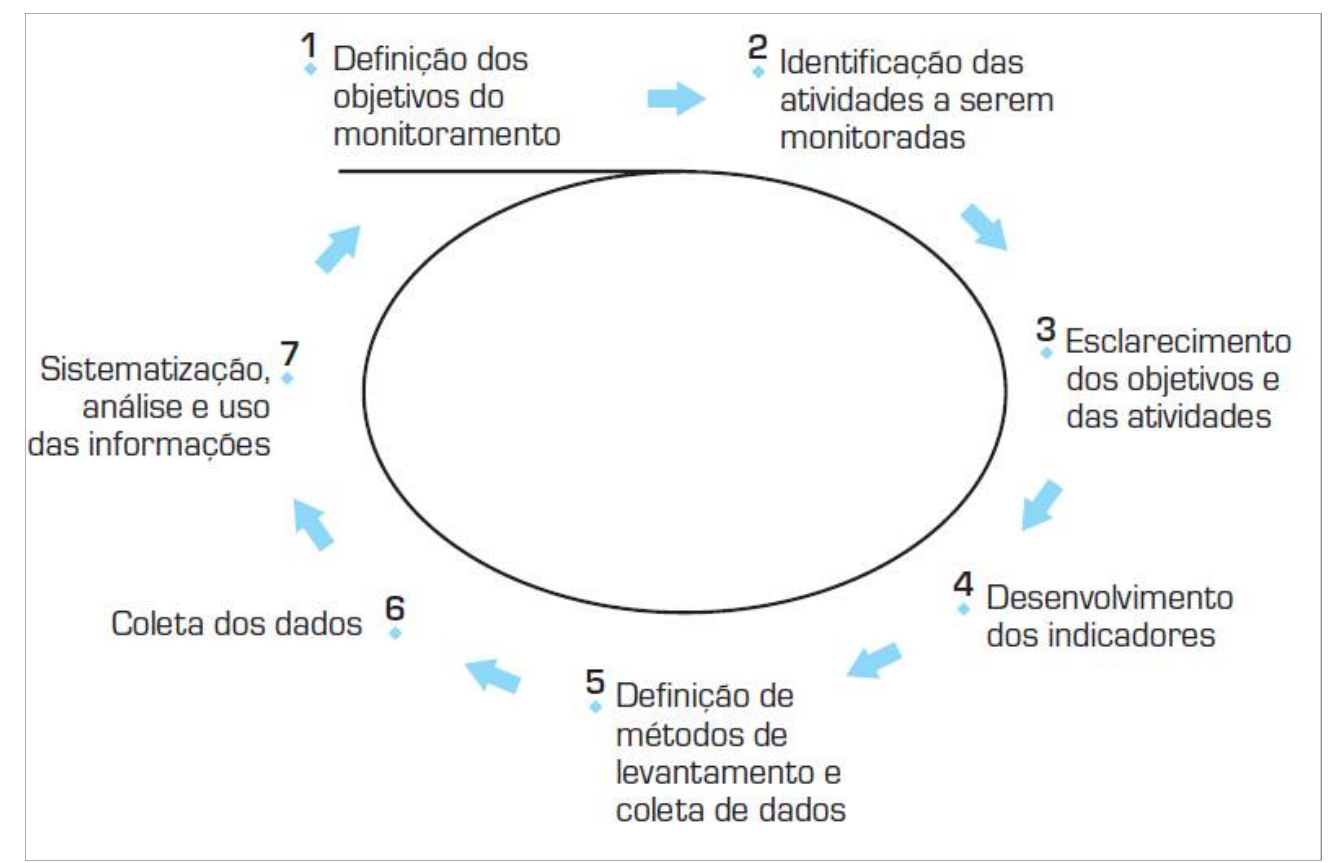

Figura 3 - Fases na implementação de um sistema de monitoramento. Fonte: SILVA, 2004.

Ferrari (2004) ao desenvolver um sistema de monitoramento dos impactos econômicos de práticas agroecológicas na zona da mata mineira elucida as seguintes etapas:

1) Descrição inicial do sistema - esta fase do monitoramento é dirigida principalmente para a observação, coleta e registro de informações, com o intuito de formar uma 
visão transversal e o mais abrangente possível sobre as características estruturais do sistema;

2) Análise dos subsistemas - realizada uma primeira aproximação, ainda que imperfeita, o passo seguinte consiste na decomposição ou dissecação desse conjunto, para analisar cada um de seus componentes (os subsistemas), do ponto de vista de sua estrutura e dos fluxos internos e externos de recursos que o caracterizam, de forma a permitir tratá-los como objeto de análise;

3) Recomposição do todo: análise do sistema - esta fase do monitoramento consiste na síntese. Conhecidos e descritos a estrutura e os fluxos presentes nos subsistemas, cabe então "reconstituir" o sistema na sua totalidade, como um conjunto mais ou menos articulado de recursos e de relações;

4) Análise comparativa dos resultados - o último passo do monitoramento é a apresentação dos resultados. Sendo a comparação o principal critério de avaliação ("não há definição sem comparação"), cabe nesta etapa emitir um juízo de valor sobre os sistemas analisados.

A IUCN (União Internacional para a Conservação da Natureza) ao discorrer sobre tipos de monitoramento relata que no passado muitas organizações focavam seu monitoramento para averiguar se o trabalho foi executado de acordo com o plano. Entretanto, esta avaliação é falha uma vez que não responde se os objetivos foram atingidos e se os mesmos foram eficazes. Assim, a avaliação da eficácia da gestão é intangível sem a presença de objetivos específicos e mensuráveis dentro do Plano de Gestão (THOMAS, MIDDLETON; PHILLIPS, 2003).

A IUCN apresenta um sistema de avaliação e monitoramento para avaliar a eficácia da gestão de uma área protegida, fornecendo orientações de como um processo de acompanhamento e avaliação devem ser concebidos e implementados; são dois principais aspectos: $i$ ) adequação do sistema de gestão e projetos - têm por objetivo avaliar as entradas do sistema de gestão e os processos utilizados; e ii) cumprimento dos objetivos da área protegida - identifica as saídas do sistema, ou seja os resultados da gestão (THOMAS, MIDDLETON; PHILLIPS, 2003).

Assim, é possível identificar seis elementos principais em um sistema passível de monitoramento que pode apontar o nível de sucesso da gestão (THOMAS, MIDDLETON; PHILLIPS, 2003):

1) Onde estamos agora? (contexto) 
2) Onde queremos estar? (planejamento)

3) O que nós precisamos? (entrada)

4) O que faremos sobre esta situação? (processo)

5) Quais foram os resultados? (saídas - atividades realizadas ou serviços fornecidos)

6) O que nós conseguimos? (saídas - conquistas reais alcançadas pela gestão)

\subsubsection{Indicadores como instrumento na análise de paisagens}

Os instrumentos mais usuais para o estudo da paisagem in loco são os indicadores ambientais. A palavra "indicador" deriva da palavra latina indicare, que significa destacar ou revelar algo. Os indicadores são informações de caráter quantitativo e qualitativo resultante do cruzamento de pelo menos duas variáveis primárias (informações espaciais, temporais, ambientais, etc.). São modelos simplificados da realidade com capacidade de facilitar a compreensão dos fenômenos, de aumentar a capacidade de comunicação dos dados brutos e de adaptar as informações a linguagem e aos interesses locais do planejador, são informações pontuais no tempo e no espaço cuja integração e evolução permitem o acompanhamento dinâmico da realidade (MAGALHÃES JÚNIOR, 2007).

Segundo Macedo (1995), indicadores correspondem a variáveis específicas de fatores ambientais, os quais permitem aferir o comportamento e/ou da funcionalidade de um determinado fator, tornando-se o elemento mais adequado para a análise quali-quantitativa das variações ambientais de um sistema.

Martos e Maia (1997) descrevem sinteticamente, indicadores como todo parâmetro quantitativo ou qualitativo capaz de evidenciar modificações no ambiente. Assim, é possível analisar o grau de perturbação ou intervenção antrópica em determinada paisagem. Os resultados de perturbação são medidos e interpretados pelas mudanças em abundância, diversidade e composição de grupos de indicadores que dependem de certos recursos do sistema (BROWN JÚNIOR, 1997).

Os indicadores ambientais são parâmetros representativos de determinados processos ambientais ou estado do ambiente, ou seja, sua situação em um dado momento, local ou região (SÁNCHEZ, 2013).

Segundo Donnelly et al. (2007), a principal função de um indicador, é sintetizar as informações, ou seja, transmitir de forma objetiva e compreensível o estado do ambiente para os tomadores de decisão. 
A seleção de indicadores necessita da diferenciação de seus graus de importância ou a sua ponderação, com o intuito de sinalizar quais são prioritários para o alcance dos objetivos estabelecidos. A atribuição de pesos pode ocorrer segundo diferentes critérios e técnicas estatísticas, mas muitas vezes não é possível ponderar sem incorporar algum nível de arbítrio ou subjetividades nos critérios de avaliação (MAGALHÃES JÚNIOR, 2007).

Segundo Santos (2004), para tornar os indicadores menos subjetivos, faz-se necessário transformar as informações em dados comparáveis. Essa transformação é comum para um sistema de análise binário, em que se definem limites aquém ou além de uma referência e responde-se de modo sim ou não. Outra estratégia é atribuir valores dentro de uma escala fixa para todas as categorias de dados avaliados; os dados podem ser transformados em números reais pela interpretação do valor do meio ao analisar características como qualidade, potencialidade, fragilidade ou capacidade de suporte.

A escala utilizada para valoração depende do indicador e dos objetivos, podendo ser aplicada alguma técnica de agregação se necessário, como, por exemplo: i) média aritmética se os indicadores são considerados igualmente importantes; ii) ponderação seguida da média aritmética, se as importâncias são diferenciadas; $i i i)$ priorização e supervalorização em casos de indicadores considerados muito importantes (MAGALHÃES JÚNIOR, 2007).

Santos (2004) alerta que não se pode apontar qualquer dado quantitativo como indicador. Para ser um indicador o dado deve ter qualidade; esta qualidade pode ser atingida ao se atentar para algumas questões. Convém destacar as seguintes: fonte de informação: se o dado for primário deve-se observar a clareza e objetividade do procedimento para sua obtenção (precisão e exatidão) para que o mesmo tenha replicabilidade científica; valores de referências: os indicadores devem apresentar, sempre que possível, limiares para comparações; representatividade: refere-se à capacidade de retratar a realidade de estudo; conectividade: conexão entre os indicadores.

Os indicadores devem ser selecionados e adaptados de acordo com o objetivo da investigação com o intuito de subsidiar possíveis planejamentos.

Segundo Besserman (2003), existe um "atraso" no mundo e no Brasil na produção de estatísticas ambientais e indicadores de sustentabilidade.

Para Santos (2004), o modelo mais usual para se trabalhar com indicadores é o sistema Pressão-Estado-Resposta desenvolvido pela OECD (Organisation for Economic Co-operation and Development), publicado em 1994 e revisto em 1998. 
sobre o ambiente, alterando a qualidade e a quantidade dos recursos naturais, ou seja, mudando seu estado. As mudanças afetam a qualidade do ambiente. A sociedade responde a essas mudanças ambientais com políticas ambientais, econômicas ou setoriais (a resposta da sociedade), almejando deter, reverter, mitigar ou prevenir os efeitos negativos da pressão do homem sobre o meio. Para cada fator de casualidade deve haver um conjunto específico de indicadores ambientais que responderão por suas características internas, ou de relação com os outros dois fatores vizinhos. Assim, o modelo organiza-se em três blocos de indicadores, ou seja, de pressão, de estado (ou condições do meio) e das respostas sociais (SANTOS, 2004, 67p.).

Hepcan (2000) desenvolveu uma série de indicadores com o intuito de analisar a compatibilidade do uso da terra com o zoneamento em vigor em um Parque na Turquia, para então identificar, quais são as áreas mais aptas às zonas de usos restritos e as zonas de usos públicos. Esses indicadores são submetidos a um escalonamento de 0 a 4 , onde 0 é insustentável e 4 muito sustentável.

O sistema de Harris (1973) revisto por Goeden (1983) propõe um grupo de indicadores com escalonamento para auxiliar na seleção de organismos a serem utilizados no controle biológico.

Segundo Heink e Kowarik (2010), ao empregar a terminologia indicadores, deve-se explicitar a definição adotada para manter a integridade na sua utilização frente à ambiguidade em relação ao conceito.

Para fins desta pesquisa, indicador compreende a representação sintética, de caráter qualitativo ou quantitativo, de uma determinada condição ou fenômeno observado no ambiente; já à agregação de inúmeros indicadores, os quais interpretam um conjunto de diferentes fenômenos, corresponde a um índice. Assim, o índice consiste no resumo de diversos indicadores.

Índices correspondem à combinação de indicadores individuais (MITCHELL; MAY; McDONALD, 1995). Para Shields, Solar e Martin (2002) índice é um indicador de ordem superior, um conjunto de indicadores agregados e ponderados.

Mais do que um indicador simples, o índice é capaz de simplificar, quantificar, comunicar e expressar de forma resumida os fenômenos complexos a partir da agregação de dados e informações; uma vez que são entendidos como o resultado da combinação de um conjunto de parâmetros associados uns aos outros por meio de uma relação pré-estabelecida, a qual dá origem a um novo e único valor (SANTOS 2004).

Neste estudo adotou-se um sistema de indicadores embasado nos sistemas propostos por Hepcan (2000), Harris-Goeden (HARRIS, 1973; GOEDEN, 1983), no qual se atribuem valores para fenômenos observados em campo, escalonando-os da situação mais favorável à 
situação menos favorável. Nesta pesquisa, para sintetizar as informações transcritas pelos indicadores, os mesmos são sistematizados para compor um único índice em cada categoria de análise. 


\section{MATERIAL E MÉTODO}

\subsection{MÉTODO}

Este estudo consiste em uma pesquisa de caráter experimental, onde se adotou o "método hipotético-dedutivo", descrito por Popper (1975). Segundo Marconi e Lakatos (2003) este método parte do levantamento de um problema, onde se tem a construção de conjecturas ou hipóteses, cujas predições devem ser submetidas a testes ou falseadas, com o intuito de verificar se as mesmas são comprovadas.

Desta forma tem-se o seguinte constructo:

\section{Problema}

O parque no ambiente urbano deve prioritariamente cumprir com as funções de Conservação, segundo Alvarez (2004) aquela que melhora a qualidade ambiental e contribui para a proteção dos recursos naturais, e Uso Público, aquela que satisfaz as necessidades de lazer da população citadina (ALVAREZ, 2004). Para tanto, devem existir neste espaço uma série de elementos que permitam que tais funções sejam tangíveis. Assim:

O parque oferece subsídios para o cumprimento das funções de Conservação e Uso Público?

Existe conciliação entre tais funções?

\section{Conjecturas e Hipóteses}

A forma pela qual o parque é concebido espacialmente não permitiria condições para o cumprimento da função de Conservação. Portanto, a manutenção da conservação passa a ter um caráter secundário frente ao uso público; tal fator fomenta a não conciliação entre as funções de uso público e conservação.

\section{Submissão a testes}

Para corroborar ou refutar as hipóteses e conjecturas levantadas, desenvolveu-se um sistema de monitoramento, por meio de indicadores para compor posterior índices, os quais podem apontar o cumprimento das referidas funções $e$ inferir o grau de estabilidade/conciliação entre elas.

Para validar a eficiência da metodologia, testou-se tal sistema em diferentes parques 
urbanos de caráter ecológico ${ }^{2}$.

Com o intuito de selecionar áreas para a aplicação da técnica proposta, optou-se pela metodologia de estudo de caso. De acordo com Yin (2010) o estudo de caso é uma investigação empírica que analisa um fenômeno contemporâneo em profundidade e em seu contexto da vida real, especialmente quando os limites entre o fenômeno e o contexto não são claramente evidentes.

Para assegurar a replicabilidade da ferramenta proposta, elegeu-se a aplicação de estudo de casos múltiplos, os quais devem seguir segundo Yin (2010) a lógica de replicação. Tal lógica distingue-se da lógica de amostragem, por presumir que os dados resultantes da amostra, representam todo o universo ou conjunto, com estatísticas inferenciais usadas para estabelecer os intervalos de confiança para os quais esta representação é considerada precisa; o procedimento de amostragem é utilizado quando o pesquisador deseja determinar a prevalência ou frequência de um determinado fenômeno; qualquer tentativa de aplicação desta lógica de amostragem aos estudos de casos estaria deslocada.

Cada caso deve ser selecionado cuidadosamente para predizer resultados similares (replicação literal) ou para que possa produzir resultados contrastantes, mas para razões previsíveis (replicação teórica) (YIN, 2010).

Ainda segundo Yin (2010) ao selecionar a quantidade das amostras para estudos de casos múltiplos, a lógica da amostragem não deve ser utilizada. Os critérios típicos relacionados ao tamanho da amostra são irrelevantes; a decisão deve preceder de um reflexo do número de replicações do caso (tanto literais, quanto teóricas) que necessitaria para tal estudo.

"Por exemplo, os pesquisadores usam um projeto de "duas extremidades" no qual os casos das duas extremidades (de alguma condição teórica importante, tal como bons ou mals resultados) foram deliberadamente escolhidos" (YIN, 2010, p. 83).

\subsection{CARACTERIZAÇÃO MACRO DA ÁREA DE ESTUDO}

\subsubsection{Curitiba: aspectos ambientais}

Fundada em 1693, Curitiba, a capital do estado do Paraná no Sul do Brasil é famosa por

\footnotetext{
2 Tipologia de Parque descrito por Mantovani (2005).
} 
seu planejamento urbano, seu sistema de transporte público e pelos resultados da política ambiental (ZIRKL, 2003).

A cidade apresenta uma altitude média de 908 metros acima do nível do mar; o município ocupa uma área de 432.418 km², sendo sua extensão de $20 \mathrm{Km}$ na direção LesteOeste e de 35 Km na direção norte-sul (ANDRADE, 2001). Segundo IBGE (2011) a população em 2011 era de 1.751 .907 pessoas.

Situa-se sobre terrenos suavemente ondulados do Primeiro Planalto Paranaense (FIGURA 4) e na região do Domínio Morfoclimático de Planaltos Subtropicais com Araucárias. Segundo Ab'Saber (2003) trata-se de planaltos de altitude média, variando entre 800 a 1300 metros, revestidos por bosques de araucárias, inclusive mosaicos de pradarias mistas e bosquetes de pinhas, ora em galerias, ora nas encostas e eventualmente nas cabeceiras de drenagem. As rochas sedimentares e basálticas estão sujeitas a desigual profundidade de alteração e as vertentes dos chapadões regionais tendem para um modelo convexo suave. Ocorre uma ligeira mamelonização nos terrenos cristalinos gnáissicos, fortemente decompostos que envolvem a bacia de Curitiba. Existem na estrutura superficial da paisagem casos de colúvios de encostas sotopostos ao microrelevo de uma topografia subatual. Esse domínio é caracterizado por grandes diferenças pedológicas e climáticas. Existem precipitações relativamente bem distribuídas por todo ano, fato que garante um caráter extensivamente perene para toda a rede de drenagem regional; o domínio comporta as paisagens menos tropicais de todo o país, a ausência das matas pluviais densas e biodiversas por todo o core deste domínio lhe concede outro ar fisiográfico e biogeográfico (AB' SABER, 2003).

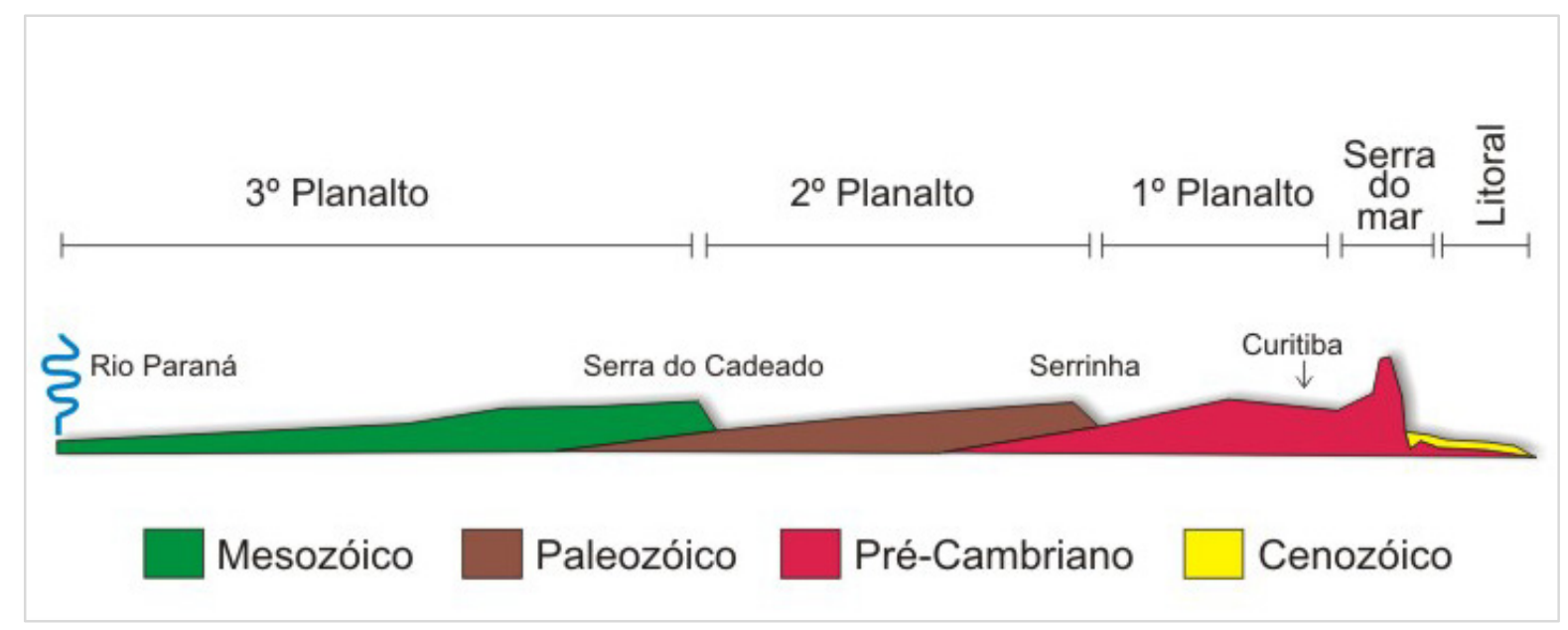

Figura 4 - Croqui do perfil da compartimentação geomorfológica estado do Paraná (E-W) segundo Maack (1968).

Fonte: MINEROPAR (2007) modificado por OLIVEIRA (2008). 
Compreende a região da Floresta Ombrófila Mista (floresta com araucária), sem influência direta do oceano, mas igualmente com chuvas bem distribuídas ao longo do ano. A composição florística é fortemente influenciada pelas baixas temperaturas e pela ocorrência regular de geadas no inverno (RODERJAN et al., 2002).

A Floresta Ombrófila Mista é uma unidade fitoecológica onde se contempla a coexistência de representantes das floras tropical e temperada, e marcada relevância fisionômica de elementos Coniferales e Laurales, onde domina a Araucaria angustifolia (Bertol.) Kuntze (Araucariaceae) (RODERJAN et al., 2002).

O clima da região é classificado de acordo com Köppen em clima do tipo $C f b$ : Clima temperado; temperatura média no mês mais frio abaixo de $18^{\circ} \mathrm{C}$ (mesotérmico); verões frescos com temperatura média no mês mais quente abaixo de $22^{\circ} \mathrm{C}$ e sem estação seca definida (IAPAR, 2012).

\subsubsection{Caracterização do contexto estudado}

\subsubsection{Produção dos espaços verdes em Curitiba}

Os parques e bosques urbanos relacionam-se de forma intrínseca com a história do planejamento e zoneamento do solo curitibano.

Segundo Andrade (2001), apoiando-se em leituras apresentadas por Oliveira (1994), Menezes (1996) e Garcia (1996), é possível segregar a história da concepção e implementação dessas áreas em três períodos políticos distintos:

i. Período de concepções sanitaristas: este período é definido e marcado pelo momento histórico compreendido entre a emancipação política do Estado do Paraná, em 1853, até a posse do prefeito Ivo Arzua, em 1962. Durante este período apenas um parque foi implantado, o Passeio Público, visando sanear uma área alagadiça e pantanosa às margens do Rio Belém que propiciava a proliferação de agentes vetores de doenças. É nesse período que são delineadas as primeiras diretrizes para a implantação de áreas verdes a partir do Plano Agache, de 1943, que previa a implantação de quatro parques e de um cemitério parque. Esses projetos de áreas verdes eram guiados sob a ótica do sanitarismo.

ii. Período de administração tecnocrata: inicia-se em 1962, com a posse do prefeito Ivo Arzua que encomenda o Plano Diretor da Cidade de Curitiba para as empresas paulistas 
Sociedade Serete de Estudos e Projetos Ltda e Jorge Wilheim Arquitetos Associados e se encerra em 1988, com o término do mandato do prefeito Roberto Requião. Como prefeito entre 1971 e 1974, Jaime Lerner, ex-presidente do IPPUC (Instituto de Pesquisa e Planejamento Urbano de Curitiba), conseguiu pôr em prática as diretrizes previstas pelo Plano Diretor. As secretarias municipais e demais órgãos executivos, em sua maioria, comandados por pessoas ligadas ao Plano Diretor, compartilhavam de uma mesma linguagem, permitindo que a implantação do Plano ocorresse de forma rápida e sem grandes conflitos. Este período foi caracterizado pela presença de técnicos, e não políticos, nos cargos decisórios da prefeitura. Os parques tinham como função primordial servirem como elementos contentores de enchentes e preservar as nascentes dos rios.

iii. Período de promoção do city-marketing: tem seu início em 1989, quando o prefeito reeleito Jaime Lerner constrói o Teatro Ópera de Arame. É um período marcado pela implantação de parques com a forte presença de construções arquitetônicas emblemáticas (Jardim Botânico, Ópera de Arame, Unilivre, Parques Tingüi e Tanguá entre outros). A função principal dos parques passa a ser a mitificação, a criação de símbolos que associem a cidade à cultura europeia dos seus imigrantes e, portanto, com qualidade de vida de primeiro mundo. Assim as áreas verdes tornam-se produtos a serem consumidos.

A criação das áreas verdes de Curitiba insere-se dentro da política de preservação ambiental e da melhoria da qualidade de vida, definida com base no II Plano Nacional de Desenvolvimento (II PND) de 1976 (OLIVEIRA, 1996).

Atualmente as áreas verdes da cidade são protegidas legalmente pelo Sistema Municipal de Unidades de Conservação (CURITIBA, 2000).

Curitiba foi primeira capital a planejar um sistema de unidades de conservação, apesar de ter sido idealizado com base na criação de uma rede de macrodrenagem urbana fundamentada em bacias de retenção. Hoje, ele contribui com a preservação da flora, fauna e de todo o ecossistema; com a conservação dos fundos de vale e na proteção do sistema natural de drenagem; com o acréscimo das opções de lazer, cultura e recreação; com a criação de uma paisagem urbana mais amena; e com a idealização de espaços de sociabilização (ANDRADE, 2009).

Determinou-se na esfera Municipal que as áreas verdes da cidade de maior relevância seriam então categorizadas como Unidades de Conservação; desta forma, a Lei Municipal 9.804/2000 (CURITIBA, 2000) (ANEXO B) que dispõe sobre as UCs no território curitibano 
define como Unidades de Conservação:

[...] áreas no Município de propriedade pública ou privada, com características naturais de relevante valor ambiental ou destinadas ao uso público, legalmente instituídas, com objetivos e limites definidos, sob condições especiais de administração e uso, as quais se aplicam garantias de conservação, proteção ou utilização pública (CURITIBA, 2000, s/p).

Estas Unidades classificam-se em nove categorias de acordo com as aptidões da paisagem e o uso da terra, são elas:

i) Áreas de Proteção Ambiental (APA): são áreas de propriedade pública ou privada, sobre as quais se impõe restrições às atividades ou uso da terra, visando à proteção de corpos d'água, vegetação ou qualquer outro bem de valor ambiental definido pela Secretaria Municipal de Meio Ambiente - SMMA;

ii) Parques de Conservação: são áreas de propriedade do Município destinadas à proteção dos recursos naturais existentes, que possuam uma área mínima de 10ha (dez hectares) e que se destinem à manutenção da qualidade de vida e proteção do interesse comum de todos os habitantes;

iii) Parques Lineares: são áreas de propriedade pública ou privada, ao longo dos corpos d'água, em toda a sua extensão ou não, que visam garantir a qualidade ambiental dos fundos de vale, podendo conter outras Unidades de Conservação dentro de sua área de abrangência;

iv) Parques de Lazer: são áreas de propriedade do Município, que possuam uma área mínima de 10ha (dez hectares) e que se destinem ao lazer da população, comportando equipamentos para a recreação, e com características naturais de interesse à proteção;

v) Reservas Biológicas: são áreas de propriedade pública ou privada, que possuam características representativas do ambiente natural do Município, com dimensão variável e que se destinem à preservação e à pesquisa científica;

vi) Bosques Nativos Relevantes: são os bosques de mata nativa representativos da flora do Município de Curitiba, em áreas de propriedade particular, que visem à preservação de águas existentes, do habitat da fauna, da estabilidade dos solos, da proteção paisagística e manutenção da distribuição equilibrada dos maciços vegetais, onde o Município impõe restrições à ocupação do solo;

vii) Bosques de Conservação: são áreas de propriedade do Município, destinadas à proteção dos recursos naturais existentes, que possuam área menor que 10ha (dez 
hectares), e que se destinem à manutenção da qualidade de vida e proteção do interesse comum de todos os habitantes;

viii) Bosques de Lazer: são áreas de propriedade do Município com área inferior a 10ha (dez hectares), destinadas à proteção de recursos naturais com predominância de uso público ou lazer;

ix) ESPECÍFICAS: são unidades de conservação criadas para fins e objetivos específicos, tais como: Jardim Botânico, Pomar Público, Jardim Zoológico e Nascentes.

Ressalta-se que o departamento de administração das áreas verdes não distingue os diferentes tipos de parques, conforme a legislação municipal (MÜLLER; OLIVEIRA; MOTTA, 2012).

A cidade de Curitiba foi selecionada como macro área de estudo, devido a forma que os parques urbanos foram concebidos e gerenciados.

\subsection{PROCEDIMENTOS TÉCNICO-OPERACIONAIS}

\subsubsection{Seleção das áreas de estudo}

Curitiba possui um total de 30 parques urbanos (CURITIBA, 2012; IPPUC, 2012; MÜLLER; OLIVEIRA; MOTTA, 2012) denominados na legislação Municipal de "Parques e Bosques".

Com o intuito de assegurar a replicabilidade em cenários distintos, selecionaram-se três unidades: o parque com a maior área $\left(\mathrm{em} \mathrm{m}^{2}\right)$; o parque com a menor área $\left(\mathrm{em} \mathrm{m}^{2}\right)$; e o parque com a área mais próxima a área média $\left(\mathrm{em}^{2}\right)^{2}$ de todos os Parques e Bosques, respectivamente, Parque Municipal Nascentes do Belém (11.178 m²), Parque Linear Cajuru $\left(104.000 \mathrm{~m}^{2}\right)$, e o Parque Municipal Passaúna $\left(6.500 .000 \mathrm{~m}^{2}\right.$ ) (TABELA 2). As coletas foram realizadas em diferentes períodos entre agosto de 2012 a janeiro de 2014.

Tabela 2 - Parques e Bosques curitibanos em área $\left(\mathrm{m}^{2}\right)$; em destaque as áreas selecionadas para os estudos de casos.

\begin{tabular}{cc}
\hline Parques e Bosques & Área $\left(\mathbf{m}^{2}\right)$ \\
\hline Parque Nascentes do Belém & 11.178 \\
Bosque Boa Vista & 11.682 \\
Bosque São Nicolau & 20.520
\end{tabular}

Continua 


\begin{tabular}{|c|c|}
\hline Parques e Bosques & Área $\left(\mathbf{m}^{2}\right)$ \\
\hline Bosque de Portugal & 20.850 \\
\hline Bosque Italiano & 23.540 \\
\hline Bosque Pilarzinho & 28.146 \\
\hline Bosque Gutierrez & 35.586 \\
\hline Parque Barigui & 37.000 \\
\hline Bosque Zaninelli & 37.000 \\
\hline Bosque do Alemão & 38.000 \\
\hline Bosque do Capão do Imbuia & 42.417 \\
\hline Parque Caiuá & 46.000 \\
\hline Bosque João Paulo II & 48.000 \\
\hline Passeio Público & 69.285 \\
\hline Bosque da Fazendinha & 75.851 \\
\hline Bosque Reinhard Maack & 78.000 \\
\hline Parque das Pedreiras & 103.500 \\
\hline Parque Linear Cajuru & 104.000 \\
\hline Parque Diadema & 112.000 \\
\hline Parque Bacacherri & 152.000 \\
\hline Parque Atuba & 173.265 \\
\hline Parque dos Tropeiros & 173.474 \\
\hline Jardim Botânico Municipal & 178.000 \\
\hline Bosque do Trabalhador & 192.016 \\
\hline Parque São Lourenço & 203.918 \\
\hline Parque Tanguá & 235.000 \\
\hline Parque da Barreirinha & 275.380 \\
\hline Parque Tingui & 380.000 \\
\hline Parque do Iguaçu & 2.956 .000 \\
\hline Parque Passaúna & 6.500 .000 \\
\hline
\end{tabular}

Fonte: adaptado de Curitiba, 2012; IPPUC, 2012; Müller; Oliveira e Motta, 2012.

\subsubsection{Desenvolvimento do sistema de monitoramento}

O sistema de monitoramento proposto sintetiza-se nas seguintes etapas:

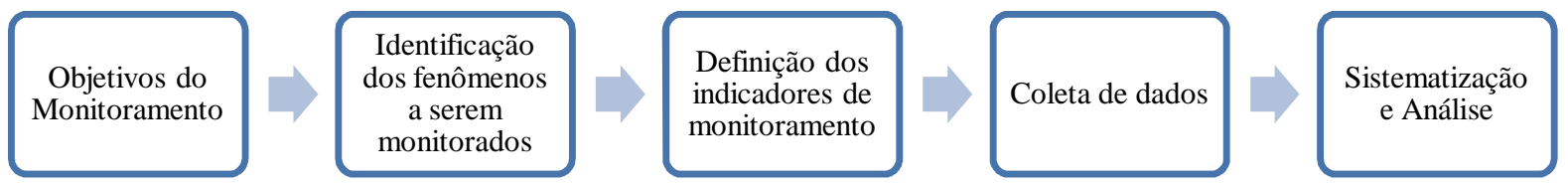

Figura 5 - Etapas do sistema de monitoramento proposto. Fonte: Adaptado de Silva, 2004. 


\section{Delimitação dos Objetivos de Monitoramento}

Os objetivos consistem em identificar se o Parque Urbano cumpre com suas funções de Conservação e Uso Público e se existe conciliação entre tais funções.

\section{Identificação dos Fenômenos a serem estudados}

Para apontar se área cumpre com as referidas funções, identificou-se:

1) Fatores naturais necessários para subsidiar a manutenção dos sistemas ambientais (conservação), tais como a presença de vegetação, ligação com fragmentos florestais, estrutura e característica do curso hídrico;

A conservação é compreendida nesta pesquisa sob a ótica de Cunha e Coelho (2010), onde os aspectos conservacionistas visam à manutenção da estrutura e funcionalidade da paisagem, ocorrendo conciliação entre os serviços ambientais e a exploração dos seus recursos pelas populações.

Ressalta-se que este estudo não tem por objetivo identificar se existem relações ecológicas nestes espaços que permitam a conservação, mas sim, a existência de elementos que possam fomentar tais relações.

2) Equipamentos necessários para permitir o uso público;

Excluem-se assim, fatores como comportamento, manutenção da qualidade das infraestruturas e os anseios dos usuários.

\section{Definição dos indicadores}

Os indicadores visaram qualificar o estado atual de cada fenômeno estudado. Elencouse um total de 14 indicadores, distribuídos em duas categorias de análise: $i$ ) indicadores de conservação (sete indicadores) e, ii) indicadores de uso público (sete indicadores) (QUADRO 3). Nesta fase também foram definidos os critérios de avaliação de cada indicador

Quadro 3 - Indicadores para qualificação das unidades estudadas.

\begin{tabular}{|l|l|}
\hline \multicolumn{1}{|c|}{ Indicadores de Conservação } & Indicadores de Uso Público \\
\hline $\begin{array}{l}\text { Ocupação na margem hídrica (elemento dominante) } \\
\text { Qualidade da vegetação (quanto à estrutura na paisagem) }\end{array}$ & $\begin{array}{l}\text { Disposição de resíduos sólidos } \\
\text { Sinalização } \\
\text { Existência de Fragmentos florestais }\end{array}$ \\
Curso hídrico (quanto ao arranjo físico) \\
Drenagem urbana & Centro de visitantes \\
Lançamento de esgoto sanitário & Equipamentos de lazer \\
Tipo de uso público & Áreas para descanso \\
\hline
\end{tabular}




\section{Coleta de dados e Sistematização}

Após a definição e sistematização dos indicadores na etapa anterior, elaborou-se uma planilha para a coleta de dados em campo (Tabela 3 e 4).

A pesquisa de campo foi registrada por meio de fotografias, para evidenciar os fenômenos identificados.

Após a coleta, seguiu-se para gabinete onde os dados foram tabulados e sistematizados em planilhas do Microsoft Office Excel.

\section{Análise}

A análise buscou responder se o parque cumpre com as funções de Conservação e Uso público, por meio de um relatório descritivo e à associação dos aspectos identificados com a literatura existente.

\subsubsection{Seleção, caracterização e avaliação dos indicadores}

Os indicadores de campo foram selecionados para qualificar o estado atual dos ambientes estudos, segregados em duas categorias de análises: Conservação e Uso Público.

Para qualificar o cenário existente adotou-se um sistema de escores embasados nas leituras de artigos que se utilizaram da técnica (HARRIS, 1973; GOEDEN; 1983; HEPCAN, 2000) e em leituras que auxiliam na formatação dos indicadores e na atribuição dos pesos (SANTOS 2004).

Para cada indicador analisado atribuiu-se pesos (escores) em uma escala entre 0 e 10 , onde 0 (zero) corresponde à característica menos favorável para área e 10 (dez) a característica mais favorável para a manutenção das funções eco e sociais.

A característica mais favorável para a manutenção da conservação corresponde à presença de elementos naturais, e a menos favorável ao ambiente mais artificializado; e a característica mais favorável para a manutenção do uso público corresponde à presença de equipamentos e infraestrutura que permitam tal uso e a menos favorável a ausência destes (TABELA 3 e 4 ). 
Tabela 3 - Classificação e escalonamento dos Indicadores de Conservação.

\begin{tabular}{|c|c|c|}
\hline Indicador & Situação & Escores \\
\hline \multirow{6}{*}{$\begin{array}{l}\text { Ocupação na margem } \\
\text { do curso hídrico } \\
\text { (elemento dominante) }\end{array}$} & i) Vegetação ciliar (contínua) & 10 \\
\hline & ii) Vegetação ciliar (parcialmente fragmentada) & 8 \\
\hline & iii) Gramíneas + indivíduos arbóreos e/ou arbustivos isolados & 5 \\
\hline & iv) Mobiliários & 3 \\
\hline & v) Solo exposto & 2 \\
\hline & vi) Impermeável & 0 \\
\hline \multirow{6}{*}{$\begin{array}{c}\text { Qualidade da vegetação } \\
\text { (quanto à estrutura na } \\
\text { paisagem) }\end{array}$} & i) Contínua ao longo do curso hídrico + fragmentos florestais & 10 \\
\hline & ii) Contínua ao longo do curso hídrico & 8,5 \\
\hline & $\begin{array}{l}\text { iii) Parcialmente contínua ao longo do curso hídrico + fragmentos } \\
\text { florestais }\end{array}$ & 7 \\
\hline & iv) Fragmentos florestais & 5 \\
\hline & v) Indivíduos arbóreos isolados & 2 \\
\hline & vi) Inexistente & 0 \\
\hline \multirow{5}{*}{$\begin{array}{l}\text { Existência de } \\
\text { Fragmentos florestais }\end{array}$} & i) Ligação com fragmentos internos e externos & 10 \\
\hline & ii) Ligação com fragmentos internos & 7,5 \\
\hline & iii) Ligação com fragmentos externos & 6 \\
\hline & iv) Isolados & 4 \\
\hline & v) Inexistentes & 0 \\
\hline \multirow{5}{*}{$\begin{array}{l}\text { Curso hídrico (quanto } \\
\text { ao arranjo físico) }\end{array}$} & i) Natural & 10 \\
\hline & ii) Retificado & 8 \\
\hline & iii) Represado & 5 \\
\hline & iv) Canalizado Aberto & 2 \\
\hline & v) Canalizado Fechado & 0 \\
\hline \multirow{4}{*}{ Drenagem Urbana } & i) Inexistente ou natural & 10 \\
\hline & ii) Drenagem com dissipação de energia em todos os pontos & 7,5 \\
\hline & $\begin{array}{l}\text { iii) Pontos de drenagem com dissipação de energia e pontos sem } \\
\text { dissipação }\end{array}$ & 4 \\
\hline & iv) Drenagem sem dissipação & 0 \\
\hline \multirow{2}{*}{$\begin{array}{l}\text { Lançamento de esgoto } \\
\quad \text { sanitário }\end{array}$} & i) Inexistente & 10 \\
\hline & ii) Existente & 0 \\
\hline \multirow{4}{*}{ Tipo de Uso público } & i) Discriminado I & 10 \\
\hline & ii) Discriminado II & 6 \\
\hline & iii) Indiscriminado I & 3 \\
\hline & iv) Indiscriminado II & 0 \\
\hline
\end{tabular}


Tabela 4 - Classificação e escalonamento dos Indicadores de Uso Público.

\begin{tabular}{|c|c|c|}
\hline Indicador & Situação & Escores \\
\hline \multirow{4}{*}{$\begin{array}{l}\text { Disposição de resíduos } \\
\text { sólidos }\end{array}$} & i) Lixeiras espaçadas em um raio de aproximadamente 100 metros & 10 \\
\hline & ii) Lixeiras espaçadas em um raio de aproximadamente 500 & 6 \\
\hline & iii) Lixeiras espaçadas em um raio de aproximadamente 1000 & 3 \\
\hline & iv) Inexistentes ou de difícil acesso ou visualização & 0 \\
\hline \multirow{4}{*}{ Sinalização } & i) Distribuídas ao longo de todo o Parque & 10 \\
\hline & ii) Presentes na entrada + pontos estratégicos & 6 \\
\hline & iii) Presentes somente na entrada & 2,5 \\
\hline & iv) Inexistentes & 0 \\
\hline \multirow{2}{*}{ Sanitários } & i) Existentes & 10 \\
\hline & ii) Inexistentes & 0 \\
\hline \multirow{2}{*}{ Centro de Visitantes } & iii) Existente com Informações sobre a área & 10 \\
\hline & iv) Inexistente & 0 \\
\hline \multirow{3}{*}{ Equipamentos de Lazer } & i) Suficientes & 10 \\
\hline & ii) Insuficientes & 4 \\
\hline & iii) Inexistentes & 0 \\
\hline \multirow{3}{*}{ Áreas para descanso } & i) Existentes com bancos e bebedouros & 10 \\
\hline & ii) Existentes com bancos & 5 \\
\hline & iii) Inexistentes & 0 \\
\hline \multirow{2}{*}{$\begin{array}{c}\text { Áreas para práticas } \\
\text { esportivas }\end{array}$} & i) Existentes & 10 \\
\hline & ii) Inexistentes & 0 \\
\hline
\end{tabular}

Para identificar se o parque cumpre com as funções supramencionadas e se há equidade entre tais usos, definiram-se graus de importância para os indicadores analisados, ou seja, ponderação dos atributos dentro das categorias de análises, com o intuito de que indicadores mais relevantes não fossem ocultados, no resultado final, por indicadores menos relevantes. A soma destes atributos corresponde à nota total 10. O critério para ponderação embasou-se nas seguintes indagações: “qual o elemento necessário para a conservação?” e "qual o elemento indispensável para o uso público?”. Assim, considerou-se que a vegetação ciliar propicia habitat para fauna, minimiza o escoamento superficial e a quantidade de sedimentos carreados até o leito hídrico, promovendo a conservação; e os equipamentos de uso comum, como 
playgrounds, pistas de caminhadas, quadra poliesportivas, academias propiciam o uso público recreacional constante; embasando-se nestes pressupostos, atribuíram-se maiores graus de importância (TABELA 5).

Tabela 5 - Ponderação dos indicadores analisados.

\begin{tabular}{ccc}
\hline Categoria & Indicador & Peso \\
\hline Ocupação na margem hídrica & 3 \\
Qualidade da vegetação (quanto à & 2 \\
estrutura na paisagem) & 1 \\
Existência Fragmentos florestais & 1 \\
Conservação & Curso hídrico & 1 \\
& Drenagem urbana & 1 \\
& Lançamento de esgoto sanitário & 1 \\
& Tipo de uso público & 1 \\
& Disposição de resíduos & 1,5 \\
Sinalização & 1 \\
Uso público & Sanitários & 1 \\
& Centro de visitantes & 2 \\
& Áreas de lazer & 1,5 \\
& Áreas para descanso & 2 \\
\hline
\end{tabular}

Após atribuir e identificar a importância devida de cada indicador, o escore final é dado pela seguinte equação:

Equação 1:

$$
S_{f}=S_{a} / S_{m} x P
$$

Onde,

$\mathrm{S}_{\mathrm{f}}=$ Escore final

$\mathrm{S}_{\mathrm{a}}=$ Escore atribuído

$\mathrm{S}_{\mathrm{m}}=$ Escore máximo

$\mathrm{P}=$ Peso do escore

$\mathrm{O} \mathrm{S}_{\mathrm{f}}$ corresponde à nota final de cada indicador; $\mathrm{S}_{\mathrm{a}}$ representa a condição observada em campo; o $\mathrm{S}_{\mathrm{m}}$, o valor máximo que aquele atributo poderia receber; e o $\mathrm{P}$, o grau de importância deste atributo frente aos demais indicadores analisados.

Para determinar se o parque cumpre com as funções de Conservação e Uso Público 
definiu-se um índice numérico entre 0 e 10, o qual consiste na soma dos Escores finais $\left(\mathrm{S}_{\mathrm{f}}\right)$ do primeiro ao enésimo valor - de cada categoria, compondo um Índice de Conservação (IC) e um Índice de Uso Público (IUP), dado pelas seguintes equações:

Equação 2:

$$
\mathrm{IC}=\sum_{i=0}^{n} S f c
$$

Onde,

$\mathrm{IC}=$ Índice de Conservação

$S f c=$ Escore finais dos indicadores de Conservação

Equação 3:

$$
\mathrm{IUP}=\sum_{i=0}^{n} S f u
$$

Onde,

IUP= Índice de Uso Público

$S f u=$ Escores finais dos indicadores de Uso Público

Após determinar o índice de cada categoria, o qual é representado por um valor numérico entre 0 e 10 , foram estabelecidas classes de cumprimento com as funções segundo a Tabela 6:

\begin{tabular}{cc} 
Tabela $\frac{6 \text { - Classes de cumprimento às funções dos Parques Urbanos de acordo com o índice }}{\text { Índice }}$ & Adequação ao cumprimento da função \\
\hline $0 \neg 2$ & Inexistente \\
$2,1 \neg 4$ & Baixa \\
$4,1 \neg 6$ & Moderada \\
$6,1 \neg 8$ & Boa \\
$8,1 \neg 10$ & Alta
\end{tabular}

Os valores obtidos para IC e IUP foram cruzados em uma matriz de interação (FIGURA 6), a qual permitiu inferir o grau de qualidade física-escológica (conservação) e social (uso público), ou seja, um índice de conciliação entre as funções. Inferem-se cinco categorias de conciliação: Alta Equidade; Boa Equidade, Moderada Equidade, Baixa Equidade e Inexistente. 


\begin{tabular}{|c|c|c|c|c|c|}
\hline IUP & $8,1 \neg 10$ & $6,1 \neg 8$ & $4,1 \neg 6$ & $2,1 \neg 4$ & $0 \neg 2$ \\
\hline $8,1 \neg 10$ & 11 & 12 & 13 & 14 & 15 \\
\hline $6,1 \neg 8$ & 21 & 22 & 23 & 24 & 25 \\
\hline $4,1 \neg 6$ & 31 & 32 & 33 & 34 & 35 \\
\hline $2,1 \neg 4$ & 41 & 42 & 43 & 44 & 45 \\
\hline $0 \neg 2$ & 51 & 52 & 53 & 54 & 55 \\
\hline
\end{tabular}

Figura 6 - Matriz de equidade entre os índices dos indicadores analisados em campo.

Onde:

IC = Índice de Conservação

IUP = Índice de Uso Público

Alta Equidade
Boa Equidade
Moderada Equidade
Baixa Equidade
Inexistente

A equidade é entendida nesta pesquisa, por meio de uma abordagem sistêmica, onde o parque é considerado um sistema aberto de acordo com Bertalanffy (2010), em que ocorre troca de matéria com seu ambiente, apresentando importação e exportação, construção e demolição dos materiais que o compõe (elementos naturais x uso público). Portanto, pode haver sistemas em equilíbrio na unidade (o parque), mas a unidade enquanto tal não pode ser considerada um sistema em equilíbrio. A partir desta compreensão de uma maneira análoga, quando as funções (Conservação e Uso Público) exercerem o mesmo peso neste sistema (o Parque), infere-se que há conciliação, ou seja, equidade, entre tais funções.

O parque que obtém status de Alta Equidade, cumpre com suas funções eco-sociais, a atual concepção paisagística é eficiente na conciliação entre o uso público e a manutenção dos aspectos naturais; Boa Equidade, o parque cumpre com suas funções, a atual gestão é eficiente, necessitando de mínimos ajustes; se o parque obtiver status de Moderada Equidade, significa que o modelo atual necessita de manejo. E se o parque enquadrar-se em Baixa Equidade ou Inexistente há equidade baixa ou inexistente, respectivamente, e o atual modelo não cumpre equitativamente com as funções de conservação e lazer, necessitando de ajustes na sua concepção paisagística e gestão. 


\subsubsection{Critérios para classificação dos indicadores}

\subsubsection{Indicadores de Conservação}

Para qualificar os indicadores partiu-se sempre de cenários mais próximos ao natural para cenários mais antropizados.

\section{Ocupação na margem do curso hídrico}

As margens hídricas são áreas protegidas por lei (BRASIL, 2012) e a necessidade de conservação destes ambientes é destacada na literatura (BINFORD; BUCHENAU, 1993; LOWRENCE et al., 1997; PAREIRA, 1997; BOTELHO; DAVIDE, 2002; KOBOYAMA, 2003; CANIL, 2006; PADILHA, 2009). A mensuração deste item não teve por objetivo o cumprimento com a legislação vigente, mas sim, qualificar sua existência ou não.

A situação mais propicia para a manutenção deste ambiente caracteriza-se como presença de "vegetação ciliar" e a situação mais desfavorável, consistem na impermeabilização das margens. Logo, determinaram-se as seguintes classes para mensuração:

i) Vegetação ciliar (contínua) presença de vegetação ciliar ao longo de todo o curso hídrico;

ii) Vegetação ciliar (fragmentada): presença de vegetação ciliar pouco fragmentada ao longo do canal hídrico;

iii) Gramado: atribuído ao visualizar apenas o cultivo de gramíneas para fins de ornamentação ao longo de todo o curso hídrico;

iv) Gramínea + indivíduos arbóreos: o parque enquadra-se nesta categoria quando as margens hídricas apresentam gramado e indivíduos arbóreos ou arbustivos isolados em mais de $60 \%$ das margens, nos domínios do parque;

v) Mobiliários: o enquadramento nesta classe dar-se-á quando, mobiliários e infraestrutura para uso público ocupam mais de $60 \%$ das margens hídricas;

vi) Solo exposto: atribuído ao visualizar mais de $60 \%$ da margem sem nenhum tipo de cobertura vegetal, com o solo desnudo suscetível a processos erosivos;

vii) Impermeável: atribuído quando aproximadamente $60 \%$ da margem hídrica, ou mais, apresenta-se impermeabilizada ao longo do perímetro do Parque. 


\section{Qualidade da vegetação (quanto à estrutura na paisagem) e Qualidade da Vegetação} (fragmentos florestais)

Estes indicadores foram elencados partindo da premissa que para que o parque possa cumprir com suas funções ecológicas se faz necessária à presença de vegetação ciliar e fragmentos, bem como a ligação entre eles, a qual permite maior fluxo gênico entre as espécies (SMITH; HELLMUND, 1993; AHERN, 1995) e a contribuição desses elementos na função social, como melhorias de ordem estética, microclimática e descanso e lazer.

Foram elaboradas categorias em que o melhor cenário existente em um parque é a presença de vegetação ciliar contínua ao longo do curso hídrico e fragmentos florestais em áreas adjacentes, permitindo a ligação entre fragmentos, e a pior situação é a inexistência de maciços florestais. A determinação das possíveis ligações foi aferida por meio de imagens de satélites disponíveis no software Google Earth (GOOGLE EARTH, 2014).

Destaca-se que esta pesquisa não teve por objetivo identificar a conectividade, ou seja, a funcionalidade destes potenciais fragmentos, mas sim a existência ou não de ligação com áreas verdes internas e externas ao parque urbano.

Classes para a avaliação do indicador "Qualidade da Vegetação (quanto à estrutura na paisagem)":

i) Contínua ao longo do curso hídrico + fragmentos florestais: classificado quando identificada a ocorrência de vegetação ciliar contínua ao longo do curso hídrico no perímetro do parque e a ligação com fragmentos florestais internos ou externos;

ii) Contínua ao longo do curso hídrico: atribuída quando verificada vegetação contínua ao longo da margem hídrica e nenhum tipo de ligação com fragmentos internos ou externos;

iii) Parcialmente contínua ao longo do curso hídrico + fragmentos florestais: classificado ao verificar vegetação esparsa ao longo do curso hídrico e ligação com fragmentos internos ou externos;

iv) Fragmentos florestais: classificado quando a área apresenta apenas fragmentos florestais isolados, sem ligação com outros fragmentos;

v) Inexistente: atribuído quando o parque apresenta apenas, espécimes isoladas de vegetação.

Classes Para a avaliação do indicador "Qualidade da Vegetação (existência de fragmentos Florestais)":

i) Ligação com fragmentos internos e externos; 

ii) Ligação com fragmentos internos;
iii) Ligação com fragmentos externos;
iv) Isolados;
v) Inexistentes.

\section{Curso hídrico}

Este indicador diz respeito à qualidade natural do sistema de drenagem hídrica. Quanto menor a intervenção humana, menor o impacto no fundo de vale. A melhor situação verificável é o canal natural e a situação mais antrópica é a canalização hídrica fechada. Elencou-se cinco classes, onde o enquadramento do curso hídrico foi dado, quando observado em campo que, $60 \%$ ou mais do canal apresenta-se em determinada classe, nos domínios do parque.

i) Natural: Atribuído quando o curso hídrico não apresenta nenhum tipo de intervenção antrópica;

ii) Retificado: atribuído quando à retificação do curso hídrico no perímetro do parque;

iii) Represado: quando o curso hídrico apresenta-se represado em toda na área de estudo;

iv) Canalizado aberto: quando o curso hídrico apresenta-se canalizado aberto (impermeabilização do canal, na secção inferior e laterais) nas dependências do parque.

v) Canalizado fechado: quando o curso hídrico apresenta-se canalizado fechado (impermeabilização do canal, na secção inferior, superior e laterais) nos domínios do parque.

\section{Drenagem urbana}

Este indicador diz respeito à drenagem urbana das águas pluviais. Sistemas de drenagem sem dissipadores de energia ocasionam e aceleram processos erosivos, modificando a estrutura do canal.

Assim, os dissipadores de energia constituem uma técnica no controle da erosão hídrica urbana (MAGALHÃES, 2001).

Embasando-se nestes pressupostos as seguintes categorias foram elencadas:

i) Inexistência de drenagem: quando não se verifica manilhas do sistema de drenagem urbana no curso hídrico presente no parque;

ii) Drenagem com dissipação de energia em todos os pontos: atribuído ao verificar 
dissipadores de energia em todas as saídas das manilhas do sistema de drenagem urbana;

iii) Pontos de drenagem com dissipação de energia e pontos sem dissipação: classificado ao verificar um sistema com dissipadores de energia em partes do sistema de drenagem;

iv) Drenagem sem dissipação: atribuído quando o sistema de drenagem não apresenta dissipadores de energia.

\section{Lançamento de esgoto sanitário}

O lançamento de esgotos sanitários propicia alteração da qualidade da água no local. Estas alterações podem ocasionar impactos estéticos, fisiológicos e /ou ecológicos (BRAGA et al., 2005). Um dos usos mais discutíveis da água em termos de qualidade é sua função de manter a flora e a fauna existentes, de maneira que não sofram alterações sensíveis; fator que é quase intangível, principalmente em meio urbano, pois qualquer modificação de um dos parâmetros da água irá alterar a distribuição dos organismos, surgindo espécies que se adaptam às novas condições impostas (DERISIO, 2012). Entretanto, o equilíbrio do meio aquático deve ser assegurado independente dos usos que se façam deste ambiente; para tal deve-se garantir a existência de concentrações mínimas de oxigênio dissolvido e de sais nutrientes (BRAGA et al., 2005).

Ressalta-se que o descarte de efluentes também desencadeia danos indiretos ao ser humano, tais como desconfortos gerados por maus odores provenientes do processo de decomposição, alterações na estética da área e a presença de espumas (DERISIO, 2012).

Assim, tendo em vista que a ligação de esgotos sanitários na drenagem caracteriza-se como fonte de poluição pontual, esta pesquisa teve por objetivo identificar a existência ou não de lançamento de esgotos por meio da rede de drenagem pluvial. Não se considerou a qualidade da água como um todo, devido à poluição da água ter caráter difuso e o fato da água estar poluída, não implica que a origem ocorra in loco, estando além da gestão do parque.

Aferiu-se este indicador em dias sem chuvas, pois o descarte de efluentes comumente associa-se a ligações clandestinas na rede de drenagem urbana.

Tal parâmetro foi segregado em duas classes: $i$ ) Inexistente, e ii) Existente.

\section{Tipo de uso público}

Elencou-se tal indicador com o intuito de caracterizar o tipo de acesso público na área. Parte-se da premissa que, quanto maiores às restrições de uso e o monitoramento, melhores as 
condições para a manutenção dos aspectos físicos e ecológicos. O uso público foi segregado em quatro classes:

i) Discriminado I: acesso restrito nas dependências do parque, com horários de visitação pré-estabelecidos e uso controlado e/ou monitorado por câmeras de vigilância e/ou segurança local;

ii) Discriminado II: Acesso restrito nas dependências do parque, com horário de visitação, porém sem controle ou monitoramento;

iii) Indiscriminado I: parque fechado com horários de visitação pré-estabelecidos e acesso público a todos os pontos;

iv) Indiscriminado II: parque aberto ao público interruptamente e com acesso a todos os pontos.

\subsubsection{Indicadores de Uso Público}

As variáveis de uso público foram elencadas com o intuito de vislumbrar elementos necessários para promover o uso público; infraestruturas para a recreação e lazer e demais equipamentos que permitam a interação da população com este espaço.

\section{Disposição de resíduos sólidos}

Este indicador caracteriza a presença de lixeiras para a disposição de resíduos sólidos gerados pelos usuários.

Devido à inexistência de literatura e normas que dispõem sobre o espaçamento mínimo necessário entre lixeiras em parques, adotou-se como valor referencial para o espaçamento entre as lixeiras no parque urbano, um raio de aproximadamente 100 metros em áreas de acesso público.

Determinou-se tal valor, a partir da premissa que, quanto maior a distância entre as lixeiras, maior a possibilidade dos usuários descartarem resíduos sólidos a céu aberto, fator que contribui para a poluição in loco. Portanto, foram identificadas as seguintes classes:

i) Lixeiras espaçadas em um raio de aproximadamente 100 metros: ideal;

ii) Lixeiras espaçadas em um raio de aproximadamente 500 metros: moderadamente apropriado;

iii) Lixeiras espaçadas em um raio de aproximadamente 1000 metros: pouco apropriado;

iv) Inexistentes ou de difícil acesso ou visualização: inapropriado. 
Os próximos indicadores foram formatados de acordo com a infraestrutura mínima necessária para o bom uso do espaço e de acordo com as aspirações dos usuários descritas por Whately et al. (2008).

Ressalta-se que não é parte integrante dos objetivos desta pesquisa, qualificar o estado de conservação e manutenção de tais infraestruturas e mobiliários.

\section{Sinalização}

Os sistemas de sinalização são partes da infraestrutura dos parques, pois consistem em um importante canal de comunicação entre a administração e seus visitantes. Uma sinalização mal feita é pior do que se ela não existisse, pois ocasiona desinteresse e perda da credibilidade pelos visitantes; os sistemas de sinalização devem apresentar clareza e precisão nas informações oferecidas, e sua configuração deve atender as necessidades dos visitantes (PIMENTEL, 2007).

Para esta pesquisa a sinalização diz respeito à presença de placas com informações sobre instalações, mobiliários, localização, alertas, informações sobre condutas aos usuários, etc; distribuídas nas seguintes classes:

i) Distribuídas ao longo de todo o parque;

ii) Presentes na entrada + pontos estratégicos: presença de sinalização na entrada e em pontos com algum tipo de atração ou alerta;

iii) Presentes somente na entrada;

iv) Inexistentes: atribuído quando não se evidencia placas em nenhum ponto do parque.

\section{Sanitários}

Os sanitários caracterizam-se como infraestruturas que podem propiciar conforto, aos usuários, sua presença é indispensável principalmente em parques de grande porte Foram elencadas duas classes: $i$ ) Existentes; e ii) Inexistentes.

Destaca-se que a pesquisa não buscou aferir as condições de manutenção de tais espaços, mas sim sua existência.

\section{Centro de Visitantes}

O centro de visitantes é um espaço destinado à interação do visitante com a área. De acordo com Santos (2005) faz parte dos objetivos de um centro de visitantes fomentar a aproximação do visitante com a natureza, permitindo a compreensão por parte do usuário da preservação, manejo, onde cada centro de visitantes deve ter seus objetivos estabelecidos em 
função da problemática da área.

Esse espaço permite ao usuário obter informações sobre a área, bem como práticas culturais e educacionais, tornando-se uma ferramenta indispensável entre a interação usuário e parque. Categorizou-se a existência deste em duas classes: $i$ ) Existente; e ii) Inexistente.

\section{Áreas de lazer}

Esse indicador visou identificar infraestruturas e equipamentos que permitam atividades recreacionais de lazer, tais como playgrounds, áreas para jogos de tabuleiros, mirantes, trilhas, entre outros, que permitam práticas recreacionais de lazer. A aferição deste indicador foi estabelecida em três classes:

i) Suficientes: quando estão bem distribuídas e atendem a maior parte de acesso público;

ii) Insuficientes: quando existem em pouca quantidade e não se encontram distribuídas nas áreas de acesso público; e

iii) Inexistentes - atribuído quando não identificado nenhum tipo de infraestrutura ou equipamento para tal fim.

\section{Áreas para descanso}

Consiste em espaços destinados ao descanso dos usuários nas dependências do parque, as quais permitem maior conforto ao uso público; segregados em três classes de avaliação:

i) Existentes com bancos e bebedouros;

ii) Existentes com bancos;

iii) Inexistentes.

\section{Áreas para práticas esportivas}

Este indicador permite aferir a existência de equipamentos e infraestruturas destinadas a práticas esportivas, como quadras poliesportivas, equipamentos de ginástica e pistas para cooper e caminhadas ou similares; o objetivo destinou-se em identificar a existência ou não de tais equipamentos, e não sua qualidade, distribuição e quantidades. Classes: $i$ ) Existentes; e ii) Inexistentes. 


\section{RESULTADOS E DISCUSSÃO}

Esta secção destina-se à descrição da aplicação do sistema proposto em diferentes áreas, com o intuito de caracterizar a aplicabilidade e replicabilidade da metodologia. Estrutura-se na discussão de três estudos de casos, com áreas, concepção física e processo de criação distinto: primeiro, o Parque Municipal Nascente do Belém, o qual se situa em área urbana, com aproximadamente $11.178 \mathrm{~m}^{2}$, cujo objetivo de criação foi à conservação das nascentes do Rio Belém, rio que nasce e deságua nos domínios municipais; Parque Linear Cajuru, situado na zona leste da cidade, local onde, anteriormente a criação, consistia em uma área de ocupação irregular, a criação do parque visou à desapropriação da área e a recuperação das margens do Rio Atuba, um dos principais afluentes do rio Iguaçu, bem como a disponibilização de áreas de lazer para a população; e o terceiro caso, o Parque Municipal do Passaúna, o qual localiza-se na zona oeste da cidade e compreende uma área de $6.500 .000 \mathrm{~m}^{2}$, foi criado com o intuito de manter a qualidade de água do reservatório para fins de abastecimento público, o manancial abastece parte da cidade de Curitiba e região metropolitana.

\subsection{PARQUE MUNICIPAL NASCENTES DO BELÉM}

O Parque Municipal Nascentes do Belém (FIFURA 7) localiza-se na região Norte do Município de Curitiba, no Bairro Cachoeira (ANEXO D) e insere-se na bacia hidrográfica do Rio Belém (ANEXO A). Está a uma distância de aproximadamente $11 \mathrm{~km}$ do centro da cidade, ocupando uma área de $11.178 \mathrm{~m}^{2}$. De acordo com a Secretária Municipal do Meio Ambiente (SMMA) de Curitiba (CURITIBA, 2012) o parque foi criado em 2001 com o objetivo de conservar e proteger o nascedouro do Rio Belém; rio endemicamente curitibano, o qual corta a cidade de norte a sul, afluindo no rio Iguaçu (CURITIBA, 2014; CURITIBA 2014).

Quanto à disponibilidade de visitação da área, verifica-se divergência entre as informações in loco e as informações disponibilizadas por canais oficiais. Segundo a o site da SMMA de Curitiba (CURITIBA, 2012), o referido parque funciona de segunda à sexta-feira das $8 \mathrm{~h}$ às $18 \mathrm{~h}$; porém, na placa de acesso a área, consta a seguinte informação: aberto de segunda-feira a domingo das 8h às 17 h (FIGURA 8). 
O parque apresenta como atrativo público: caminhos entre a vegetação, ponte e um mirante para a nascente.

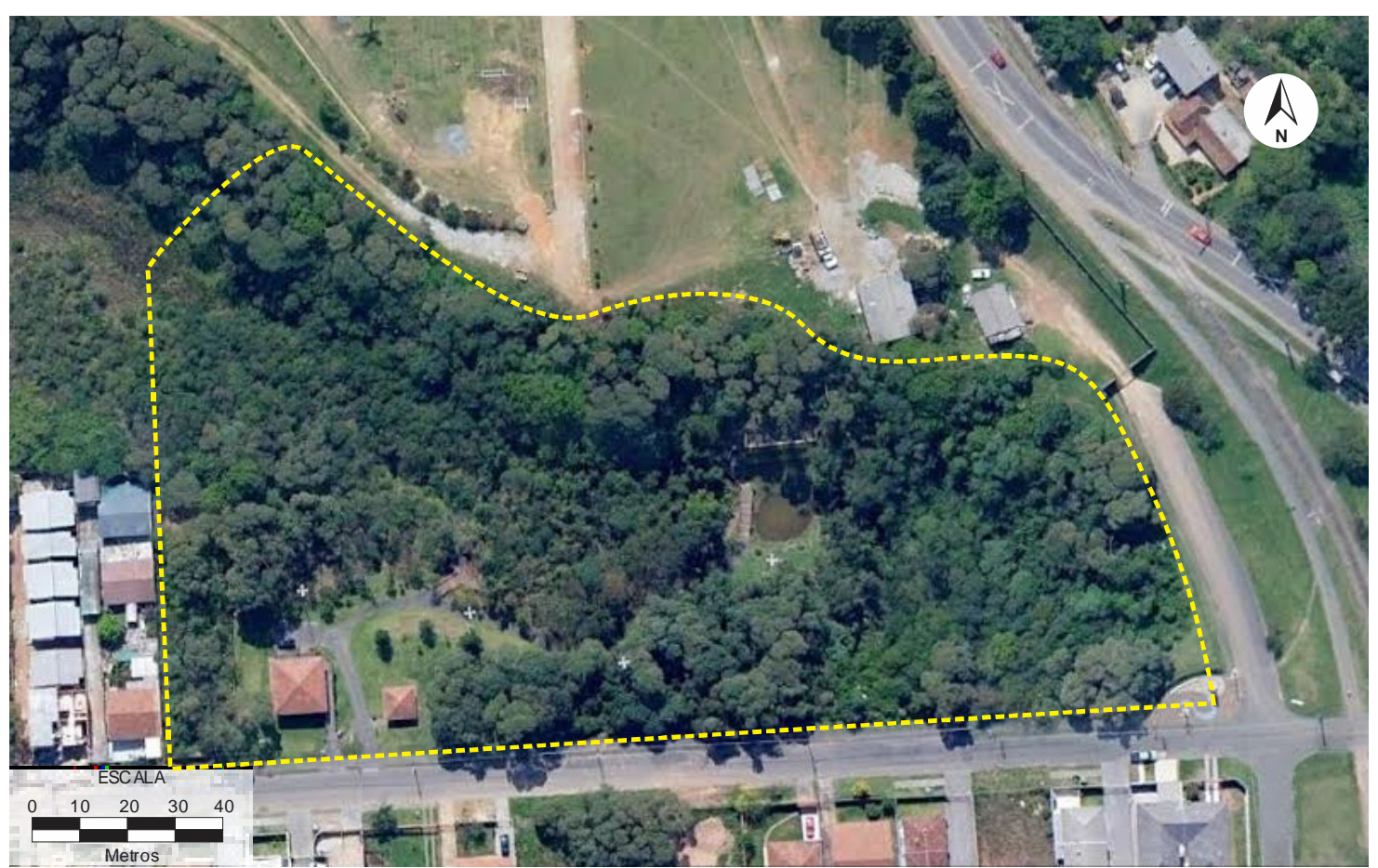

Figura 7 - Vista parcial do Parque Municipal Nascentes do Belém, no Bairro Cachoeira em Curitiba-PR; em destaque na cor amarela os limites aproximados da área.

Fonte: Adaptado de GOOGLE EARTH, 2014.

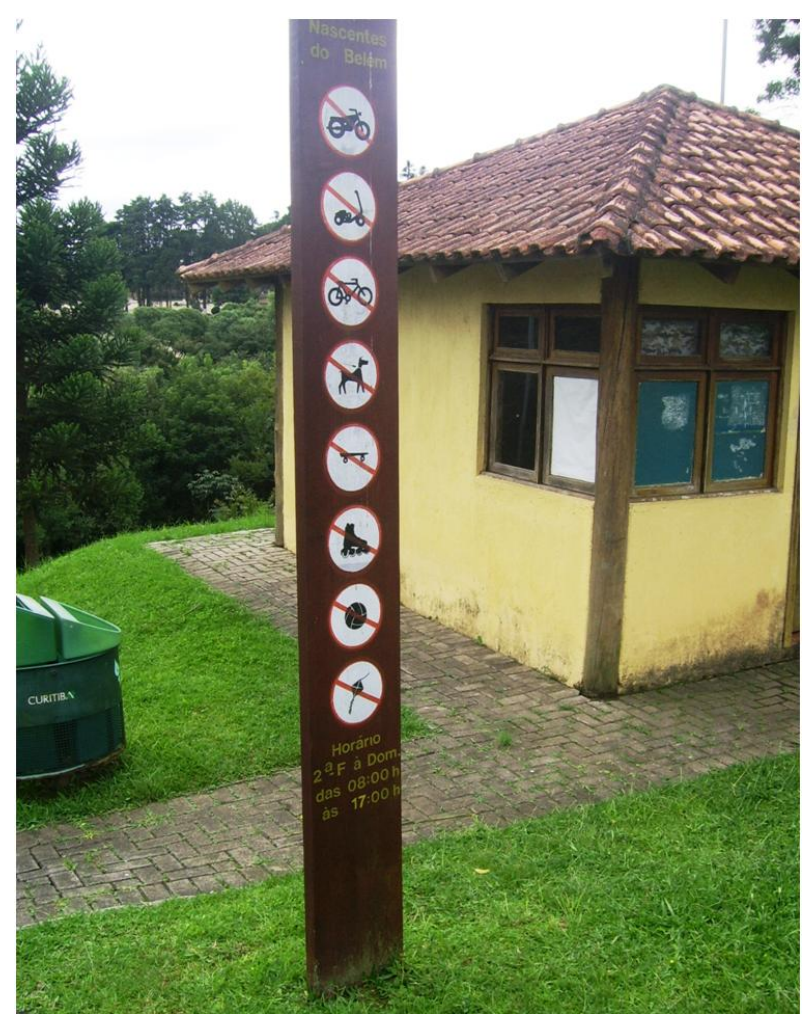

Figura 8 - Placa presente na entrada do Parque Municipal Nascentes do Belém, Curitiba-PR, com informações sobre os horários de visitação e restrições de uso nas dependências. 
Destaca-se que, em visitas realizadas ao local, verificou-se que a área abriga o CRASCachoeira (Centro de Referência de Assistência Social Cachoeira) o qual funciona de segunda a sexta-feira das 8 às 17 horas (FIGURA 9), em uma área que originalmente deveria ser destinada ao centro de educação ambiental, previsto no projeto inicial do parque.

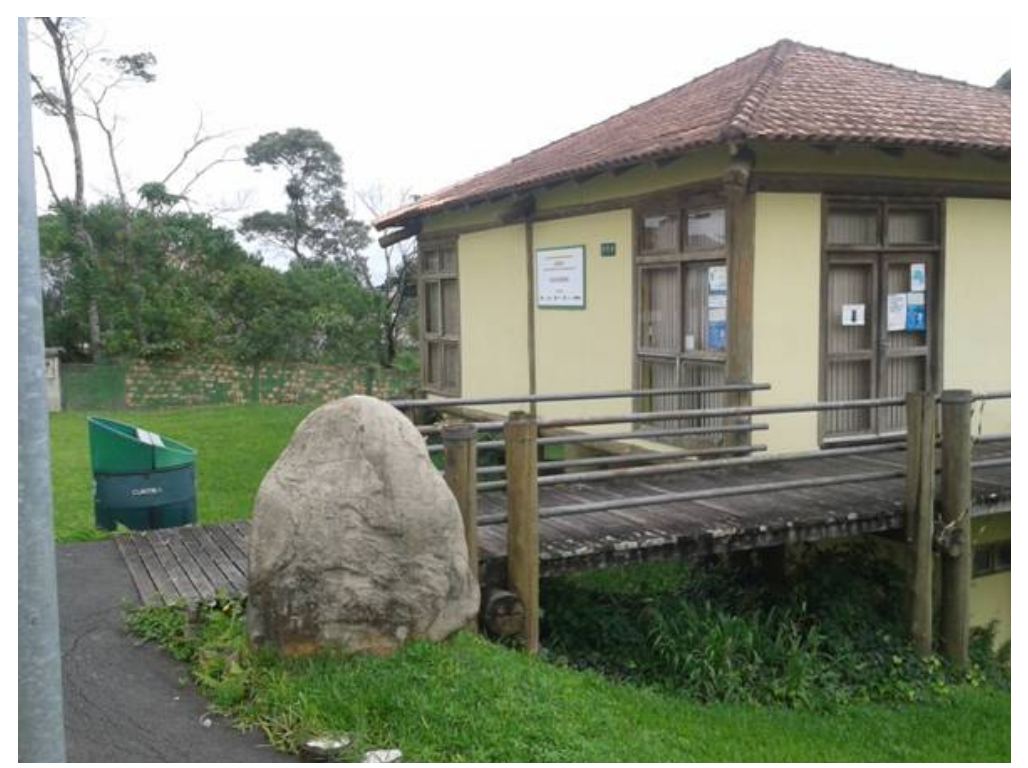

Figura 9 - Vista parcial das instalações do CRAS - Cachoeira, no Parque Municipal Nascentes do Belém.

\subsubsection{Indicadores de Conservação}

A margem hídrica, em todo o domínio do parque é caracterizada pela ocorrência de vegetação (FIGURA 10), a qual consiste no principal foco de conservação em virtude das nascentes. A vegetação mais dispersa ocorre próxima ao olho da nascente, onde verificam-se gramíneas e espécies ornamentais. Já ao longo do canal, a vegetação encontra-se densa, formando um extrato herbáceo e outro arbóreo-arbustivo, os quais inviabilizam o acesso público até o curso hídrico, fator desejado para área, a qual visa intrinsecamente aspectos conservacionistas. De acordo com os dados analisado, o parque obteve um $S a$ (Escore Atribuído) de 10 pontos no quesito ocupação da margem hídrica. Quanto à estrutura da vegetação na paisagem, identifica-se continuidade da vegetação ciliar com fragmentos vegetacionais em áreas lindeiras ao parque; portanto, atribuiu-se a nota 10 no quesito qualidade da vegetação e fragmentos florestais (FIGURA 11). 


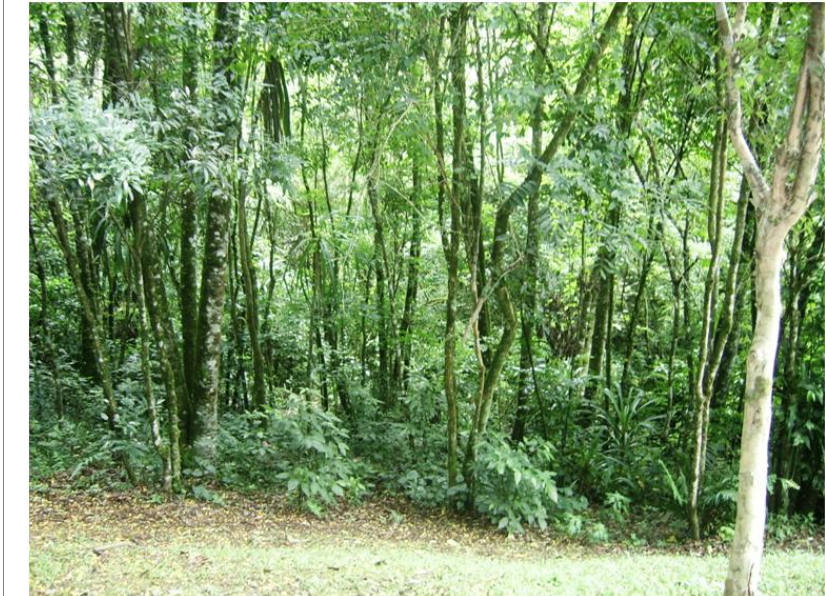

(a)

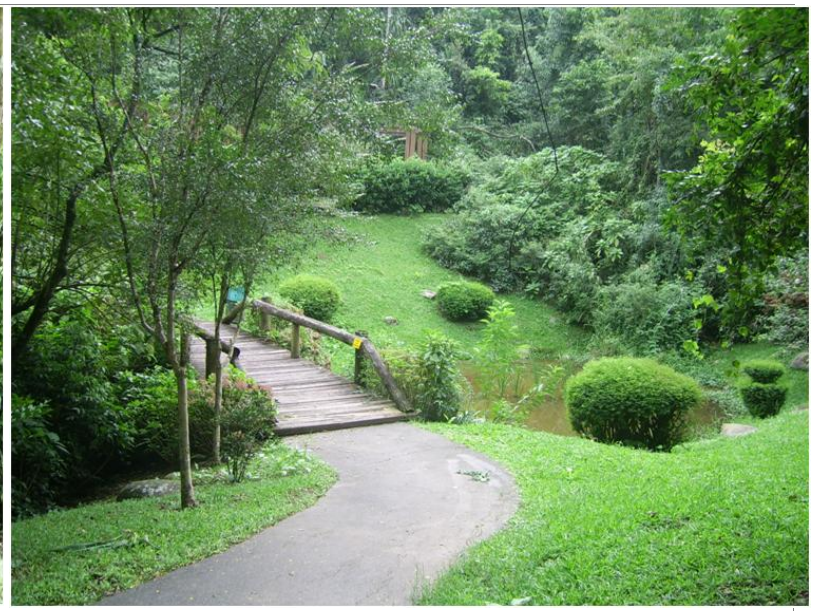

(b)

Figura 10 - Vegetação lindeira ao curso hídrico no Parque Municipal Nascentes do Belém: (a) vegetação ao longo do canal; (b) vegetação próximo a nascente.

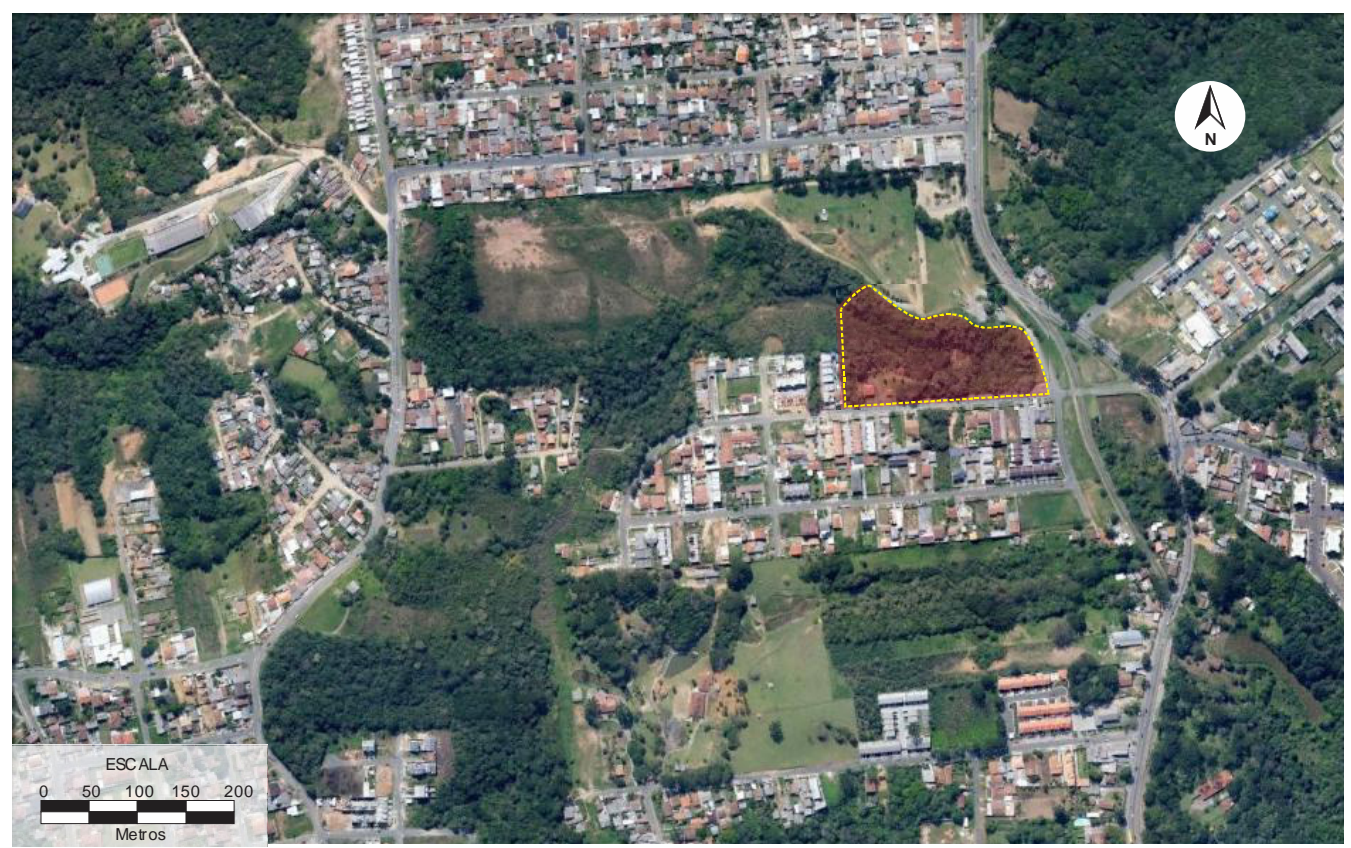

Figura 11 - Vista aérea do Parque Municipal Nascentes do Belém, em Curitiba-PR, e a ligação com áreas verdes adjacentes; em destaque circulado na cor vermelha os limites aproximados do parque.

Fonte: Adaptado de Google Earth, 2014.

Por se tratar de uma área cujo objetivo principal é a conservação das nascentes, não há aparente intervenção no canal hídrico, bem como manilhas do sistema de drenagem urbana de águas pluviais interligadas ao meio hídrico. Assim, classificou-se o canal e a drenagem como "natural".

O lago da nascente apresenta aspectos de sólidos suspensos, caracterizados pela água turva; ao longo do canal, as águas denotam características mais límpidas; o curso d’água apresenta-se inodoro em todos os pontos; não foi visualizada a presença de ligações clandestina do descarte de efluentes, tal indicador recebeu o escore 10. 
Apesar da aparência de água limpa e há não diluição de dejetos, observa-se, a existência de um cemitério; tal informação já foi diagnosticada em pesquisa conduzida por Brasilio (2005). Segundo o autor, na margem direita, em encosta voltada para o rio, há existência de um cemitério, em expansão, o que pode determinar, logo de início, que o rio já "nasce poluído", pela conexão de águas subsuperficiais com o leito do rio.

Ribeiro et al. (2009) ao realizarem ensaios microbiológicos na nascente do Rio Belém no perímetro do parque, qualificaram a presença de bactérias pertencentes ao grupo Escherichia coli em quantidades que inviabilizam a água para consumo humano de acordo com a legislação vigente ${ }^{3}$, ou qualquer outra atividade que implique o contato direto ou indireto. Tal grupo de microrganismos só se desenvolve no trato intestinal de animais de sangue quente (incluindo o homem), e quando encontrado em meio hídrico, indicam que a água teve contato com material de origem fecal, implicando a potencial existência de organismos patogênicos (BRAGA et al., 2005; RIBEIRO et al., 2009).

A conservação da vegetação esta intimamente relacionada à qualidade da diversidade de fauna e avifauna, além da qualidade de água. Em investigação realizada por Bracht (2008), referente à qualidade de água do Rio Belém, relatou que o IQA (Índice de Qualidade de Água) do trecho da nascente pode ser classificado como "Boa". Entretanto, a pesquisa descreve altos níveis de turbidez relacionados ao excesso de sólidos suspensos presentes na nascente, alertando a necessidade da reabilitação da vegetação, visto que próximo a nascente predomina gramíneas, as quais necessitam de manutenção constante (corte de grama), sendo este um dos fatores que contribuem para o aporte de sedimentos ao curso d'água.

O Parque Municipal Nascentes do Belém é composto de estruturas que o classificam como uso "Discriminado II", tais como cercamento, portões e horário de visitação pública pré-estabelecido, mas não conta com a presença de vigilância e monitoramento do uso por guardas e/ou câmeras, permitindo que o parque fique suscetível a ações vandálicas e ao acesso em horários irregulares.

De acordo com os indicadores propostos, os itens voltados para conservação, com exceção do tipo de uso público ( $S a$ - Escore atribuído - de 6 pontos), obtiveram um $S a$ de 10 pontos (FIGURA 12). Tal fator corrobora a ideia que tais elementos propiciam a manutenção dos sistemas físicos e ecológicos, permitindo que o parque cumpra com sua função de Conservação.

\footnotetext{
${ }^{3}$ Portaria do Ministério da Saúde no 2.974/2011.
} 


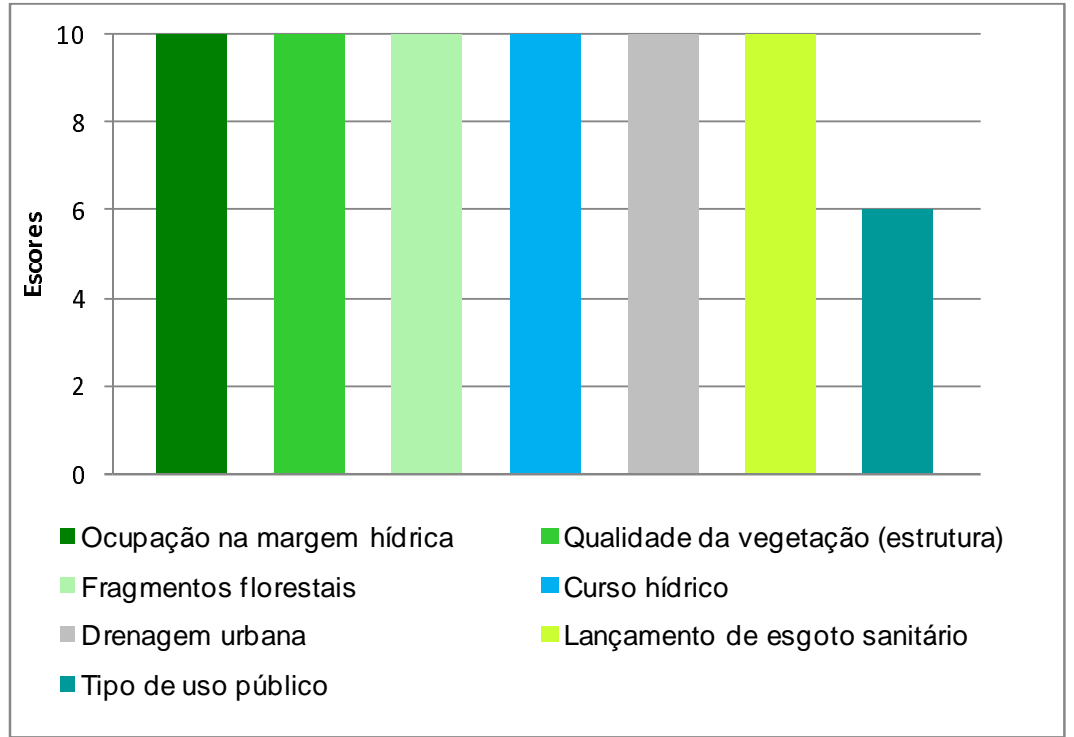

Figura 12 - Síntese dos escores atribuídos aos indicadores de Conservação aplicados no Parque Municipal Nascentes do Belém, Curitiba- PR.

\subsubsection{Indicadores de uso público}

As lixeiras estão presentes e bem espaçadas (média de 20-30 metros) ao longo de todo o parque; tal fato corrobora a ideia de que, quanto menor o espaçamento entre as lixeiras, menor o descarte de resíduos em áreas inapropriadas, visto que, não se evidenciou resíduos em nenhum ponto (solo, água ou infraestruturas), além das lixeiras.

Quanto à sinalização, em toda a área existe apenas uma placa junto a uma rocha com inscrições memoriais da criação e função do parque, e duas placas informativas: uma na entrada com o nome e horário de visitação, e outra placa junto à ponte alertando sobre o piso escorregadio (FIGURA 13). Fazem-se necessárias sinalizações com informações próximas a nascente, para elucidar a localização da nascente principal do Rio Belém e placas informando o usuário a respeito do "mirante". Assim para o quesito "Sinalização" o parque recebeu a nota 6, denotando a existência de placas na entrada e pontos estratégicos.

Segundo informações no site oficial (CURITIBA, 2012) a área conta com a presença de sanitários, mas, não foi possível identificar espaços destinados a este fim; não existem estruturas ou algum tipo de sinalização que indique tal finalidade. O quesito "sanitários" recebeu nota "0- ausente", pois mesmo que a área dispunha deste equipamento não esta disponível ao uso público. 


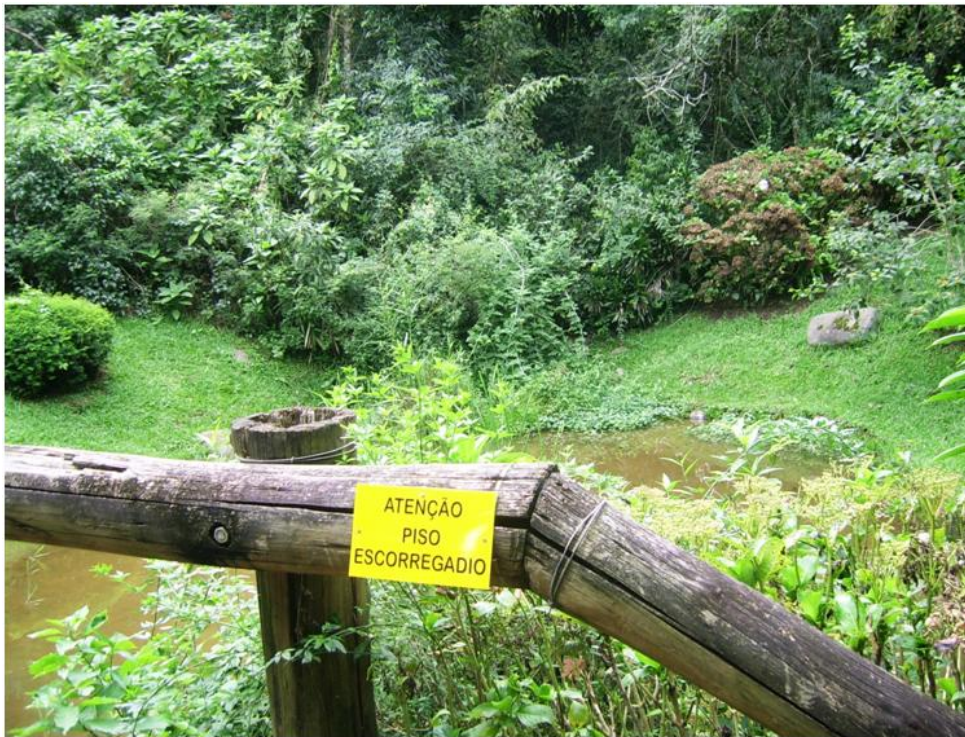

(a)

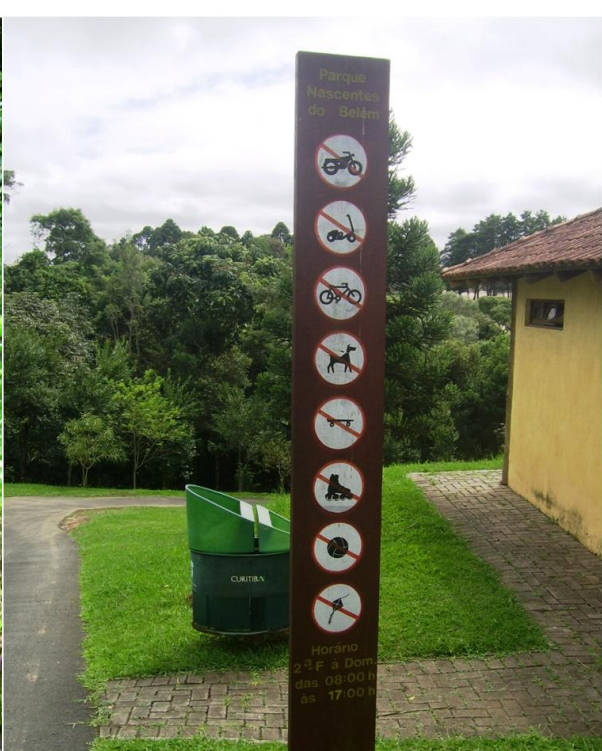

(b)

Figura 13 - Sinalização no parque Municipal Nascentes do Belém: (a) placa de alerta na ponte da nascente; (b) sinalização no acesso com informações sobre dias e horários de funcionamento e condutas para o usuário.

O Parque Municipal Nascentes do Belém oferece pouco equipamento para uso público.

Não existe nenhum equipamento de uso constante; destaca-se na área como equipamentos de lazer, uma trilha pavimentada que traça um caminho da entrada do parque, passa pela ponte de madeira sobre o pequeno lago da nascente, seguido por uma escadaria rústica de madeira que leva até o mirante (FIGURA 14), perfazendo um percurso de aproximadamente 150 metros; visto a não existência de equipamentos de uso constante que permitam que os usuários permaneçam na área, atribuiu-se a nota 4 - Insuficientes para o quesito áreas de lazer.

O parque não possui equipamentos para atividades físicas ou práticas recreativas. Foi computada a nota "0" para o item "áreas para práticas esportivas". Mesmo que o parque não apresente estruturas para práticas recreacionais, consiste em um bom espaço para quem deseja silêncio e descanso.

Cabe salientar que à inexistência de equipamentos de lazer, permitem que o espaço encontre-se completamente vazio aos finais de semana, em visitas realizadas na área nos finais de semanas não foi possível visualizar usuários e nenhum tipo de segurança como guardas ou câmeras de vigilância.

A falta de equipamentos contribuiu para que o parque torne-se um ambiente isolado da comunidade na qual esta inserida, pois a população não vislumbra formas de utilização.

Brandalize e Bollmann (2009) ao realizarem uma pesquisa acerca do conhecimento da existência do Rio Belém, pela população residente nos domínios da bacia hidrográfica do 
mesmo rio, destacou que os moradores das proximidades do parque, desconhecem o rio e até mesmo a existência do Parque.

Tais fatores podem comprometer a conservação, contribuindo para que a mesma fique susceptível aos processos de marginalização. É indispensável à participação da população para que o parque possa cumprir com suas funções e exercer suas potencialidades.

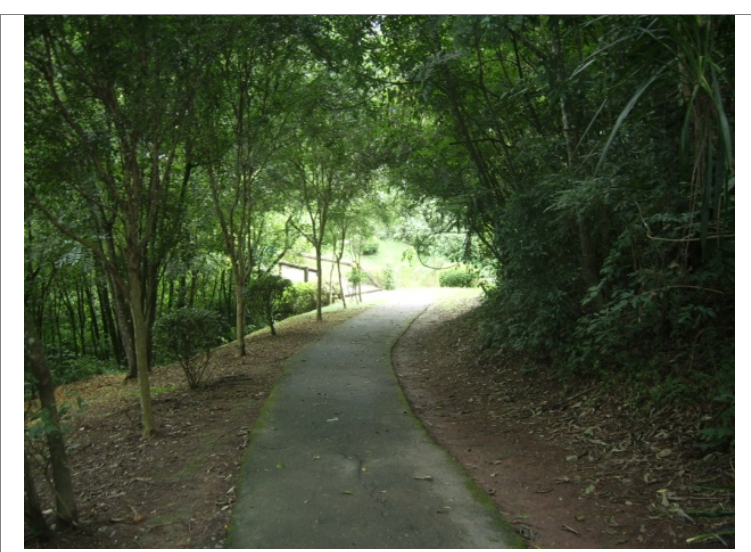

(a)

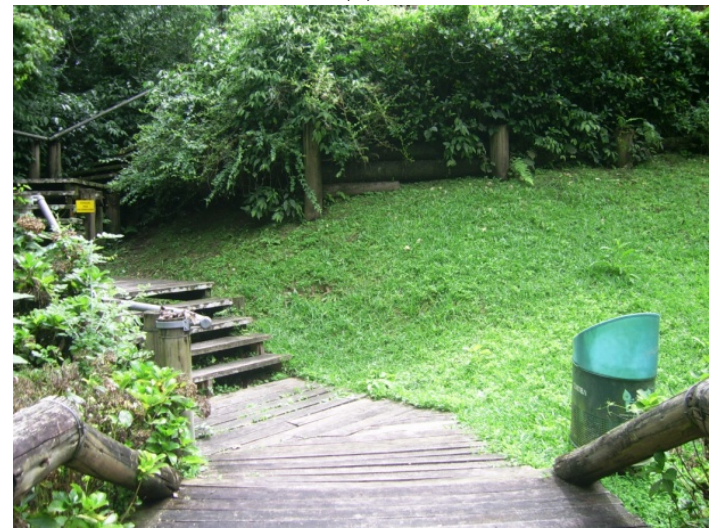

(b)

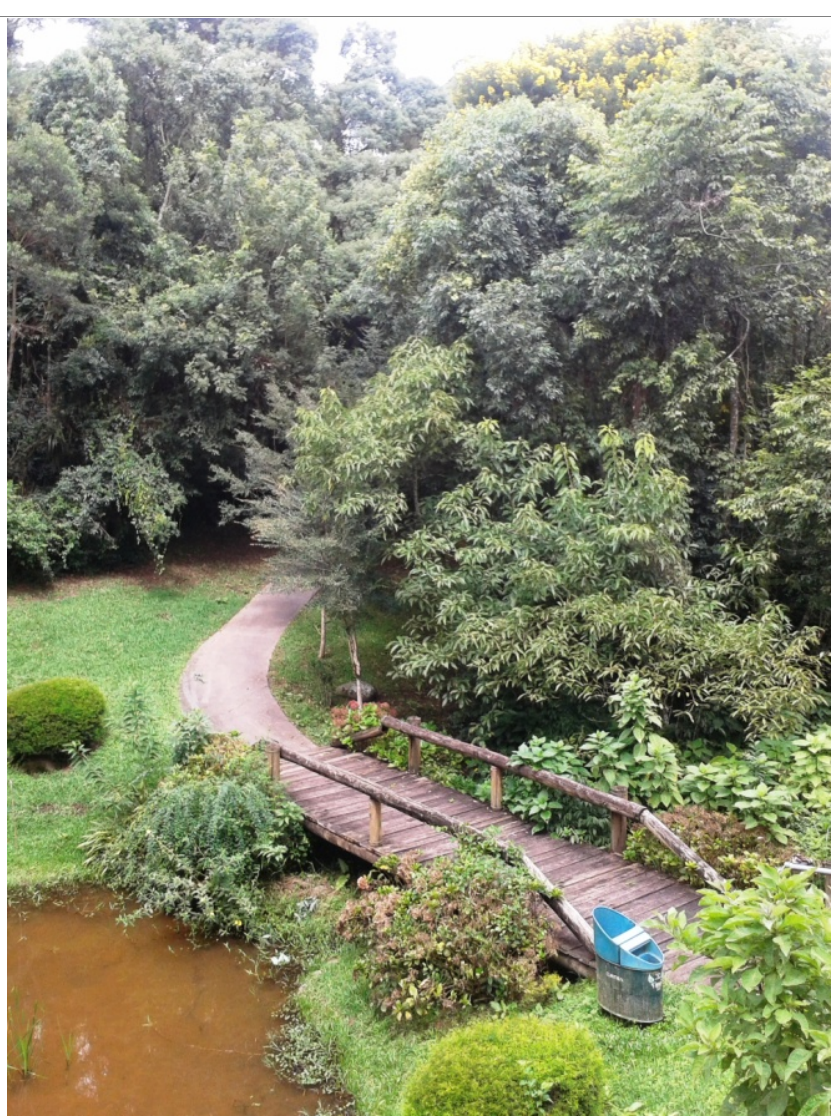

(c)

Figura 14 - Vista das infraestruturas destinadas ao uso público no Parque Municipal Nascentes do Belém, Curitiba-PR: (a) trilha entre a vegetação sentido a ponte da nascente; (b) escadaria entre a ponte e o mirante; (c) vista do mirante para o lago da nascente e a ponte.

Não existem espaços destinados exclusivamente para o descanso, tais como bancos e bebedouros de uso público, assim no quesito "áreas para descanso" de acordo com o protocolo proposto o parque recebeu nota " 0 - ausente".

Zafalon e Silva (2012) com o intuito de investigar se o Parque cumpre com os seus propósitos de implantação, constataram que:

[...] seu propósito de dar suporte para a prática de atividades de educação ambiental não está em andamento. Existe o Programa Olho D’Água, mas a sua efetivação não se faz presente no local, a estrutura está sendo utilizada como uma sede de apoio social à população do entorno, retratando, dessa forma, que o propósito de criação da unidade de conservação não está sendo atendido (ZAFALON; SILVA, 2012, p.149). 
Assim, torna-se evidente que o Parque não cumpre com as funções de Uso público, uma vez que os elementos que receberam melhores ranqueamentos foram: disposição de resíduos, seguido por sinalização e áreas para lazer, respectivamente, 10, 6, e 4. Elementos que deveriam subsidiar o uso público como mobiliários de recreação e lazer receberam a nota 0Ausente (FIGURA 15).

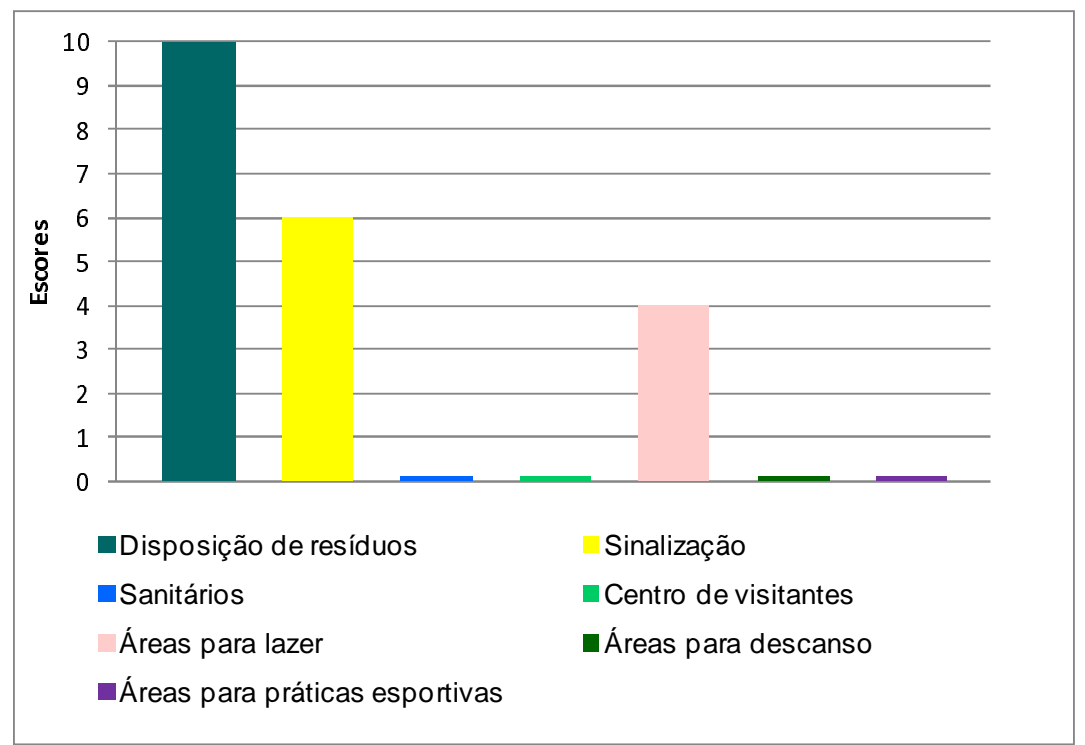

Figura 15 - Síntese gráfica dos escores atribuídos aos indicadores de Uso Público aplicados no Parque Municipal Nascentes do Belém, Curitiba-PR.

De acordo com a ferramenta proposta, o Parque Municipal Nascentes do Belém recebeu um IC de 9,6 pontos, fator que indica que o parque apresenta elementos que subsidiam os processos de conservação, permitindo que o parque cumpra com tal função. Para os atributos de uso público computou um IUP de 2,7 pontos, o que permite inferir que área cumpre de forma mínima com as funções de uso público (FIGURA 16; TABELA 7).

Quanto à conciliação entre o uso público e a conservação, ocorre discrepância entre as duas vertentes analisadas, uma vez que os aspectos conservacionistas se sobressaem. $\mathrm{O}$ o parque é bem servido de elementos naturais que subsidiam a manutenção de tais aspectos; já os elementos que deveriam suprir as necessidades de lazer da população, ficam em um plano secundário, não existem mobiliários de lazer e recreação, áreas para descanso, ou qualquer outra infraestrutura que possibilite tais usos. Ao analisar estes atributos de forma sistêmica por meio da matriz de equidade (FIGURA 17), o parque apresenta "pouca equidade" entre as funções de conservação e de uso público; não há conciliação entre tais funções. 


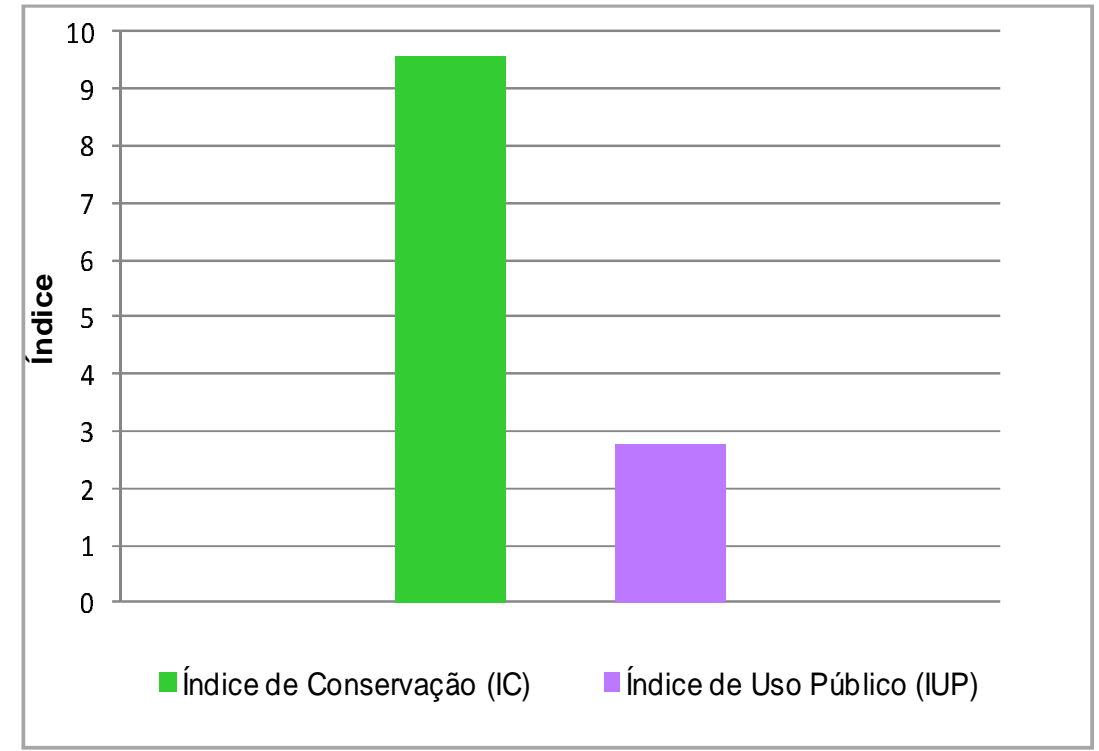

Figura 16 - Síntese gráficas dos índices de Conservação x Uso Público no Parque Municipal Nascentes do Belém, Curitiba (Paraná).

Tabela 7 - Síntese dos indicadores de conservação e uso público e suas respectivas pontuações e índices no Parque Municipal Nascentes do Belém, Curitiba, Paraná.

\begin{tabular}{|c|c|c|c|c|c|}
\hline Categoria & Indicador & $\begin{array}{l}\mathrm{E}_{\mathrm{a}}(\text { Escore } \\
\text { atribuído) }\end{array}$ & $\begin{array}{l}\text { Peso do } \\
\text { escore }\end{array}$ & $\begin{array}{l}\mathbf{E}_{\mathrm{f}}(\text { Escore } \\
\text { final) }\end{array}$ & Índice \\
\hline \multirow{7}{*}{ Conservação } & Ocupação na margem hídrica & 10 & 3 & 3 & \multirow{7}{*}{9,6} \\
\hline & $\begin{array}{c}\text { Qualidade da vegetação (estrutura na } \\
\text { paisagem) }\end{array}$ & 10 & 2 & 2 & \\
\hline & Fragmentos florestais & 10 & 1 & 1 & \\
\hline & Curso hídrico & 10 & 1 & 1 & \\
\hline & Lançamento de esgoto sanitário & 10 & 1 & 1 & \\
\hline & Drenagem urbana & 10 & 1 & 1 & \\
\hline & Tipo de uso público & 6 & 1 & 0,6 & \\
\hline \multirow{7}{*}{ Uso Público } & Disposição de resíduos & 10 & 1 & 1 & \multirow{7}{*}{2,7} \\
\hline & Sinalização & 6 & 1,5 & 0,9 & \\
\hline & Sanitários & 0 & 1 & 0 & \\
\hline & Centro de visitantes & 0 & 1 & 0 & \\
\hline & Equipamento de lazer & 4 & 2 & 0,8 & \\
\hline & Áreas para descanso & 0 & 1,5 & 0 & \\
\hline & Áreas para práticas esportivas & 0 & 2 & 0 & \\
\hline
\end{tabular}




\begin{tabular}{|c|c|c|c|c|c|}
\hline IUP & $8,1 \neg 10$ & $6,1 \neg 8$ & $4,1 \neg 6$ & $2,1 \neg 4$ & $0 \neg 2$ \\
\hline $8,1 \neg 10$ & & & & & \\
\hline $6,1 \neg 8$ & & & & & \\
\hline $4,1 \neg 6$ & & & & & \\
\hline $2,1 \neg 4$ & 14 & & & & \\
\hline $0 \neg 2$ & & & & & \\
\hline
\end{tabular}

Figura 17 - Matriz de equidade entre o Índice de Conservação (IC) e o Índice de Uso Público no Parque Municipal Nascentes do Belém, Curitiba-PR; em destaque na Coluna 1 e Linha 4 (14), a classificação do referido Parque - Baixa Equidade.

\subsection{PARQUE LINEAR CAJURU}

O Parque Linear Cajuru (FIGURA 18) localiza-se na porção Leste do Município à aproximadamente uma distância de $11 \mathrm{~km}$ do centro de Curitiba, no bairro Cajuru (ANEXO E) e insere-se na bacia hidrográfica do Rio Atuba, sub-bacia do Iguaçu (ANEXO A). O acesso principal fica na Rua Santa Lúcia, porém existem vários acessos secundários distribuídos ao longo de todo o Parque.

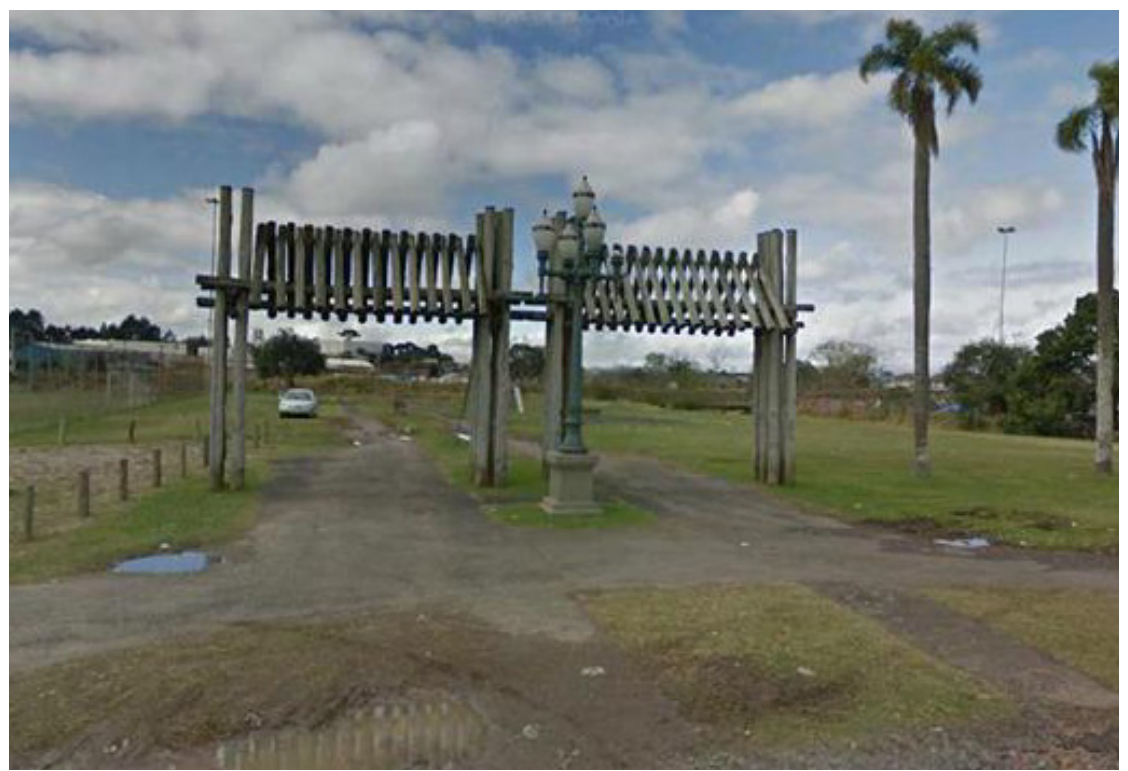

Figura 18 - Vista geral do portal de acesso para o Parque Linear Cajuru na Rua Santa Lúcia, Curitiba, Paraná. Fonte: GOOGLE EARTH, 2014.

O objetivo central de criação do Parque foi resgatar as funções ambientais do Rio Atuba, delineando uma área de aproximadamente 2.100 metros lindeiros ao referido Rio, 
totalizando uma área de $104.000 \mathrm{~m}^{2}$, cujas margens foram recuperadas com espécies nativas da unidade fitogeográfica local, em 2002/2003 pela SMMA Curitiba com a participação de outras entidades municipais, com o intuito de reabilitar a vegetação ciliar e prevenir processos erosivos. A implantação do parque também possibilitou a regularização de aproximadamente 400 famílias que residiam às margens hídricas, transferindo-as para locais com melhores condições (MÜLLER; OLIVEIRA; MOTTA, 2012; CURITIBA, 2012).

O rio Atuba é afluente da margem direita do rio Iguaçu, possui suas nascentes na região Serrana do Açungui, próximo à sede municipal de Colombo e, segue em direção a Bacia Sedimentar de Curitiba, assim cruza os municípios de Colombo, Curitiba e Pinhais (NUNES; RIBEIRO; FIORI, 2006). A bacia hidrográfica do rio Atuba possui várzeas com a presença de neossolos flúvicos, hidromórficos e planície sujeita a inundações periódicas (ZANELLA, 2006). A região onde encontra-se o parque esta suscetível a inundações em períodos de elevadas precipitações (ANEXO B).

\subsubsection{Indicadores de Conservação}

Ao percorrer o parque verifica-se o plantio de espécies arbóreas isoladas, advindas do processo de recuperação da margem, intercaladas com espécies arbustivas, principalmente exóticas invasoras, como a Mamona (Ricinus communis L.) e gramíneas (FIGURA 19). Portanto, atribuiu-se para o indicador ocupação a margem hídrica o escore 5, o qual corresponde à ocupação com gramíneas e indivíduos arbóreos e/ou arbustivos isolados.

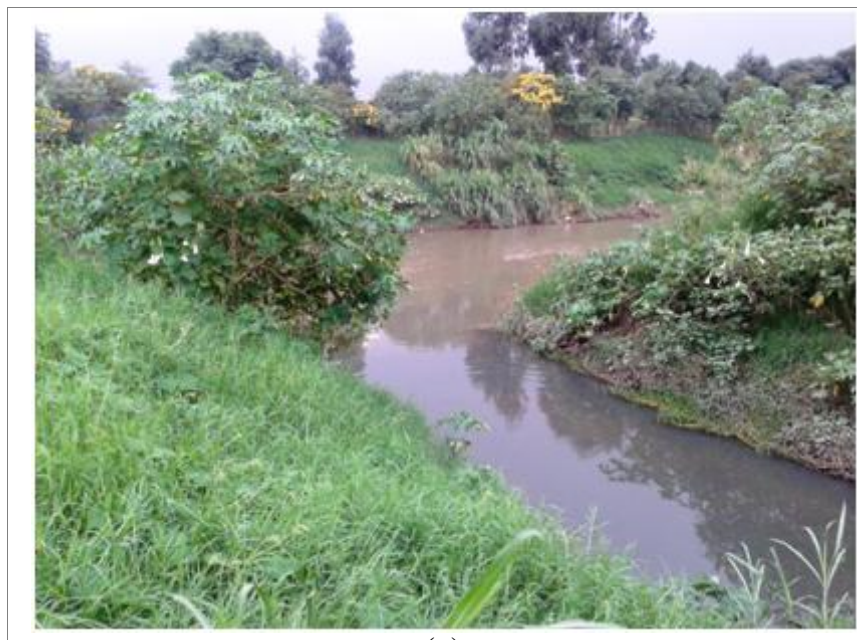

(a)

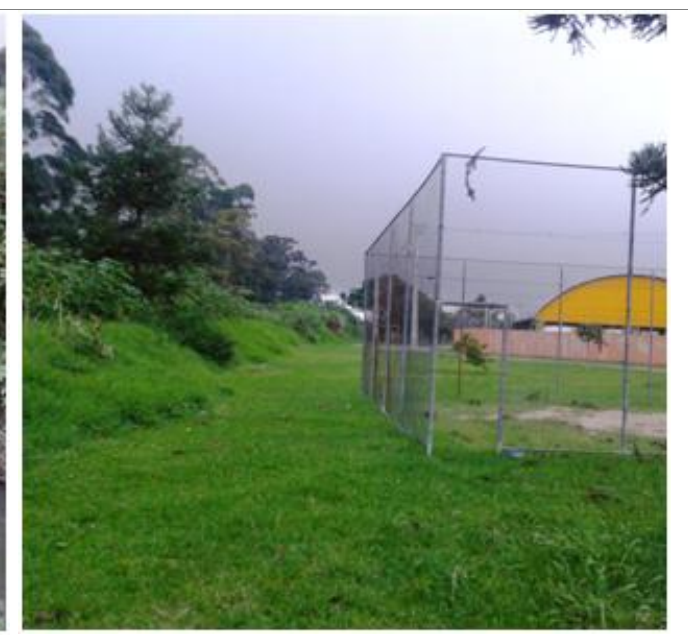

(b)

Figura 19 - Vista parcial da ocupação da margem hídrica no Parque Linear Cajuru, Curitiba-PR: (a) encontro do córrego da Rua Teófilo Otoni com o Rio Atuba; (b) aspecto parcial da vegetação e mobiliários de uso público lindeiros ao Rio Atuba. 
Gobbi e Ostrensky Neto (2011) alertam para a ineficiência das ações de acompanhamento após plantio das mudas em projetos de recomposição da vegetação ciliar na bacia do Alto Iguaçu. O não acompanhamento das mudas permite que boa parte das espécies cultivadas não se desenvolvam, caracterizando indivíduos arbóreos isolados, tal como ocorre no Parque Linear Cajuru.

Quanto à estrutura da vegetação na paisagem, diagnostica-se a ocorrência de indivíduos arbóreos isolados. Não existem fragmentos florestais nos limites do parque e/ou em áreas adjacentes; a partir de imagens de satélite não é possível identificar fragmentos de vegetação em áreas limítrofes, por conseguinte nenhum tipo de ligação. Atribuiu-se para o fator ligação com fragmentos florestais, a nota 0 - Inexistente, e para a qualidade da estrutura da vegetação nota 2 (indivíduos isolados). Na Figura 20 observa-se a área verde do Parque Cajuru e a ausência de fragmentos florestais em áreas lindeiras, e, por conseguinte, a ocupação do uso da terra estritamente urbana, caracterizando esta, a matriz da paisagem, corroborando o fator de não-conectividade.

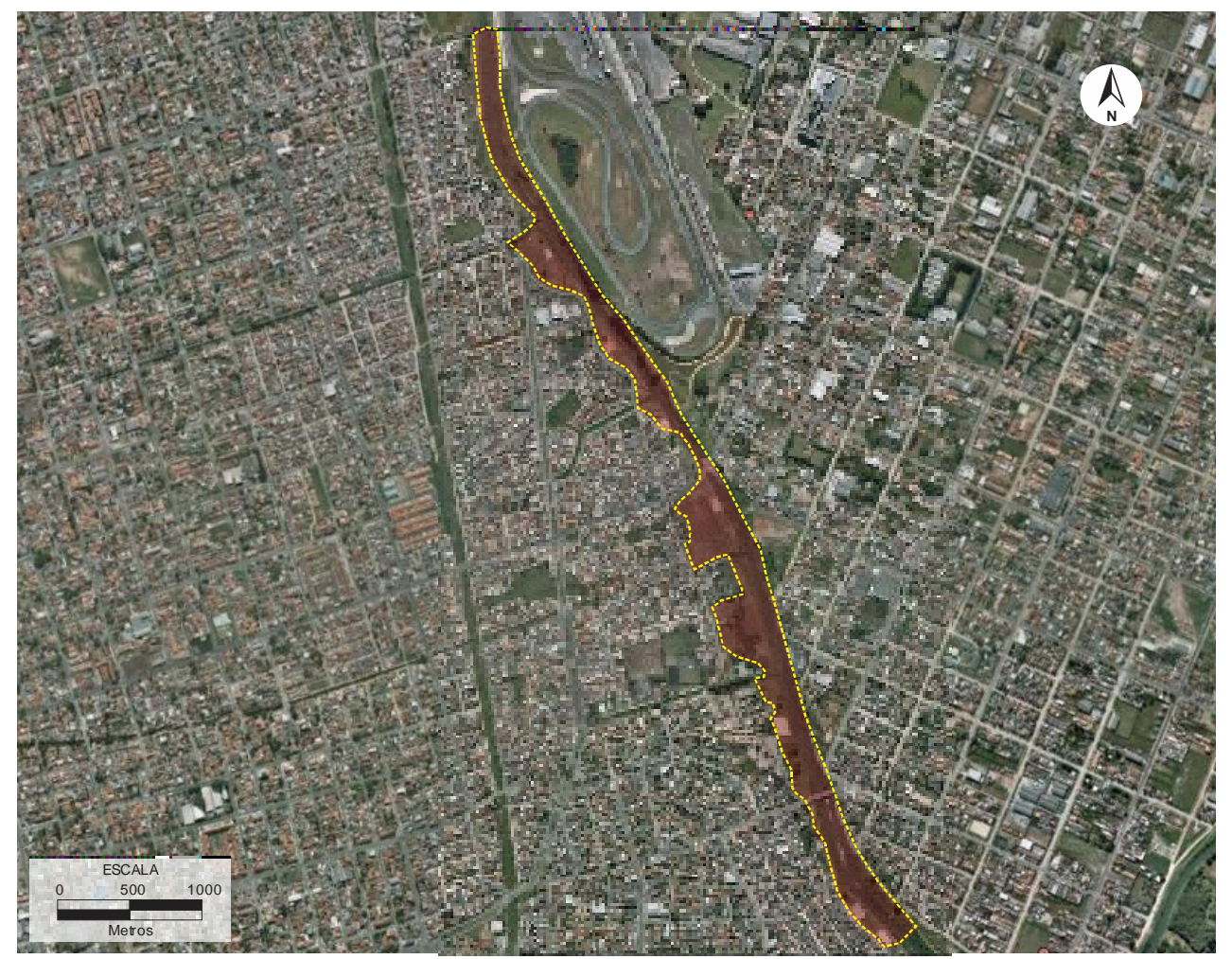

Figura 20 - Vista aérea do Parque Linear Cajuru e uso e ocupação da terra predominante (urbanização) em áreas lindeiras; em destaque na cor vermelha, o início (ao norte) e o término (ao sul) dos limites aproximados da área.

Fonte: Adaptado de GOOGLE EARTH, 2014.

Zanella (2007) ao realizar um estudo no Bairro Cajuru, relata que a cobertura vegetal esta praticamente ausente; a vegetação ciliar, que no passado ocupava as áreas de acumulação 
inundável, apresentam-se como pequenas manchas de vegetação secundária junto às margens do rio, as quais têm pouco significado na minimização do escoamento superficial. A autora também alerta que as condições de uso e ocupação das terras na bacia, incidem em uma maior vazão do rio, permitindo que a área esteja susceptível a processos de inundações.

Nos domínios do parque não existe nenhum tipo de intervenção expressiva no canal, tais como represamento, ou canalização. Verifica-se o acúmulo de sedimentos nas margens em determinados trechos e um traçado reto e simétrico do rio Atuba; infere-se, portanto que o mesmo sofreu um processo de retificação, atribuindo-se a nota 8, para o critério canal hídrico. Devido ao histórico de inundações relatado por Zanella (2006) na região, o processo de retificação tem por objetivo escoar com maior velocidade as águas, para evitar possíveis inundações.

Também é possível notar a presença de banco de sedimentos no leito do rio, o que indica processos erosivos e assoreamento devido aos padrões de ocupação do uso da terra na bacia. A que se acrescentar que de acordo com Drew (2011), um dos efeitos subsidiários e retroalimentadores das intervenções dessa natureza, em rios, consiste na alteração da velocidade das águas, aceleração dos processos erosivos, o que implica a presença de sedimentos no leito do rio.

Outro fator agravante da retificação de canais, é que ao acelerar a velocidade da água, aumenta-se a vazão a jusante da intervenção, causando consequentemente inundações. Para Geisssler e Loch (2004), as primeiras obras públicas para o controle de inundações na cidade de Curitiba, desconsideraram as causas reais do problema e transferiram as consequências para os municípios à jusante, tal problema poder ser visualizado no mapa disponibilizado pela IPPUC (2001), no qual se observa que a maior parte das áreas sujeitas a inundações encontrase nos limites do município (ANEXO B).

O Rio Atuba, nos limites do parque, apresenta drenagem dos córregos afluentes; durante as visitas não foi identificada nenhuma manilha que indicasse apenas drenagem de águas pluviais. Portanto, atribuiu-se a nota 10 - natural, ao critério drenagem urbana. Fazem-se necessários novos diagnósticos que visem identificar de forma minuciosa a presença de estruturas que indiquem apenas a drenagem de águas pluviais, pois acredita-se que este tipo de infraestrutura exista na área devido ao porte do rio e a importância do mesmo na contribuição da drenagem e ao excesso de impermeabilização da bacia que pode ser visualizado por meio de imagens de satélite, as quais indicam o predomínio de áreas edificadas e consequentemente impermeabilizadas, fazendo-se necessário à coleta de águas pluviais e posterior lançamento no rio mais próximo (Atuba). Ainda ressalta-se que apesar de 
não evidenciado manilhas de drenagem exclusivamente de águas de chuvas, tais estruturas foram identificadas em córregos afluentes ao rio.

Em todo perímetro percorrido não foram visualizados pontos de lançamento de esgoto sanitário, atribuído a nota 10 para o referido quesito. Entretanto mesmo que não seja possível identificar fontes poluidoras in loco, o rio Atuba no trecho do bairro Cajuru, apresenta alto grau de poluição e inundações periódicas, representa um foco de disseminação de doenças veiculadas por meio hídrico (TAVARES, 2005).

Segundo o monitoramento da qualidade de água de 1992 a 2009 em diferentes pontos do rio Atuba, a qualidade encontra-se poluída e o rio no trecho Cajuru é enquadrado como “classe 4" de acordo com a Resolução n Conama 357/2005, devido aos baixos teores de OD (Oxigênio Dissolvido), alta DBO (Demanda Bioquímica de Oxigênio), Fósforo Total e Coliformes Fecais (presença de E. coli), a classe 4 foi evidenciada em mais de $90 \%$ das amostras analisadas pelo órgão ambiental competente (IAP, 2009).

Ainda de acordo com a referida Resolução (CONAMA, 2005), as águas doce de Classe 4 podem ser destinadas apenas a Navegação e harmonia paisagística.

Tais fatores implicam que a água é imprópria para uso humano; contato de forma direta e/ou indireta podem conotar risco à saúde, tal característica reforça a necessidade de vegetação ciliar, com o objetivo de inibir o acesso público ao meio hídrico. Ainda há que se destacar que segundo informações descritas por Geissler e Loch (2004), 80\% das doenças registradas na cidade de Curitiba são hidroveiculadas. Assim, a vegetação consiste em uma medida mitigadora de tal cenário.

O tipo de uso público do parque classifica-se em Uso Indiscriminado II, uma vez que não existem restrições de uso, cercamento, seu funcionamento é interrupto e os usuários podem ter acesso a todos os pontos. De acordo com informações no site oficial da SMMA de Curitiba, o Parque apresenta funcionamento de segunda à sexta-feira das $8 \mathrm{~h}$ às $18 \mathrm{~h}$, mais uma vez verifica-se incongruência entre as informações oficiais e a realidade. Tal característica aferiu a nota 0 (zero) para o indicador "uso público".

Dentre os atributos de Conservação os indicadores que receberam melhor ranqueamento foram à drenagem urbana e lançamento de esgoto, seguido por canal hídrico, o qual apresenta condições físicas satisfatórias, obtiveram os escores 10, 10 e 8, respectivamente. Os itens relacionados à vegetação encontram-se em condições abaixo da média, podendo não permitir condições propícias para a manutenção dos sistemas naturais (FIGURA 21). 


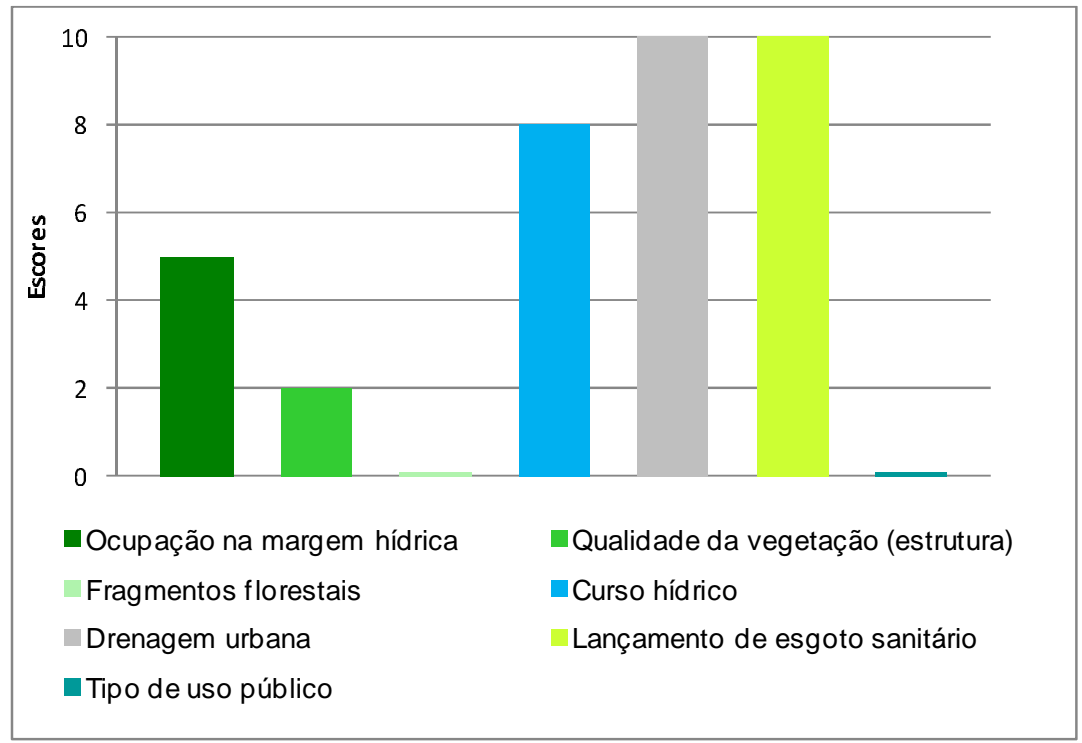

Figura 21 - Síntese gráfica dos escores atribuídos aos indicadores de conservação aplicados no Parque Linear do Cajuru, Curitiba, Paraná.

\subsubsection{Indicadores de Uso Público}

Os indicadores de Uso Público visaram identificar e qualificar os elementos necessários para que o parque cumpra com sua função social.

Identifica-se no parque lixeiras apenas no trecho próximo ao portal de entrada principal localizado na Rua Santa Lúcia, em outros pontos, como exemplo, próximo à pista de skate, não se visualiza lixeiras. Considerando que o parque tem aproximadamente 2100 metros de extensão e só é possível evidenciar lixeiras próximas à entrada principal, atribuiu-se para o quesito lixeira a nota 3 , a qual considera que as lixeiras estejam espaçadas em um raio de aproximadamente 1000 metros (FIGURA 22).

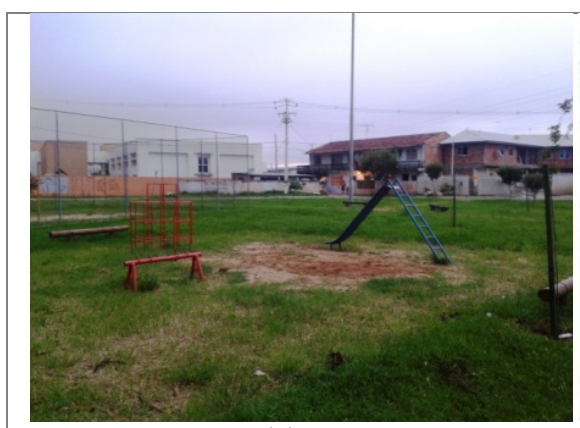

(a)

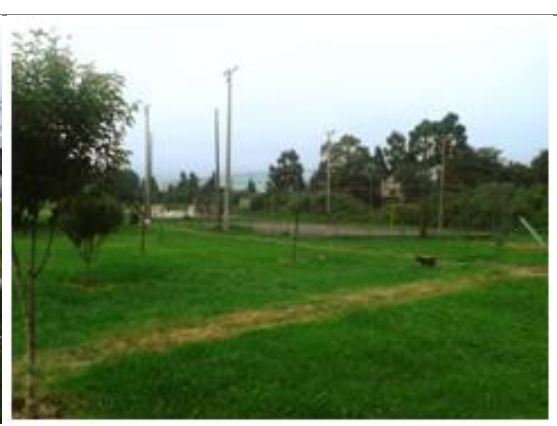

(b)

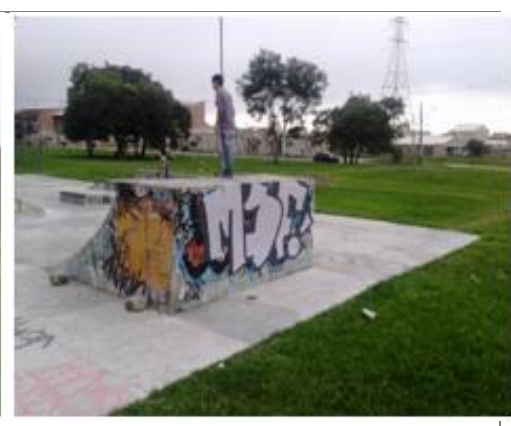

(c)

Figura 22 - Vista parcial das áreas de recreação no Parque Linear do Cajuru, Curitiba-PR, onde nota-se a ausência de Lixeiras. 
Não existe sinalização em nenhum ponto do parque. Ressalta-se que o espaço possui inúmeras áreas de acesso, tal fator permite que o usuário não tenha conhecimento ao menos do nome da área que esta usufruindo, o que implica em um potencial uso indesejado, como depredação da área, ou contato direto com áreas impróprias ao uso público, como rio. Assim, o quesito Sinalização recebeu a nota 0 - Inexistente.

Não foi possível identificar sanitários. Próximo ao campo de futebol verifica-se a presença de uma estrutura similar a banheiros. Porém, não é possível afirmar, pois não existem placas com informações sobre a utilização deste ambiente, além do mesmo estar fechado durante os períodos de coleta. Ressalta-se que, mesmo que exista sanitários nesta localização, o mesmo não poderia atender a todos os usuários devido à extensão do parque.

Também não é identificado a existência de Centro de Visitantes e nenhum outro tipo de infraestrutura que desempenhe função de sensibilizar ambientalmente a população local, bem com informar sobre histórico de criação. A educação ambiental em centro de visitantes na área de conservação permite que os usuários conheçam os atributos de conservação e seja um novo propagador de educação ambiental, sendo este um elemento estruturante no papel da conservação. Para ambos os itens, Sanitários e Centro de Visitantes, atribuiu-se a nota O Inexistente.

O parque é bem servido com equipamentos de lazer e áreas para práticas esportivas em todo seu perímetro, constituindo-se estes os principais atributos da área. Verifica-se playgrounds, pista de skate, quadras poliesportivas, campo de futebol, pista de ciclismo e caminhada (FIGURA 23). Atribuindo-se a nota 10 a ambos os itens. Ressalta-se que a técnica não buscou avaliar a qualidade desses equipamentos, mas sim, a sua presença ou ausência, ou seja, evidenciar se o parque apresenta estruturas que permitam o uso público.

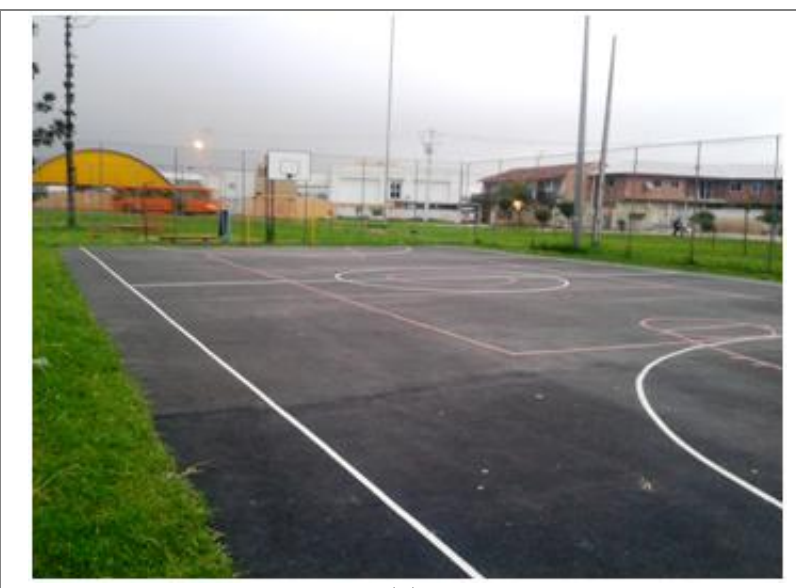

(a)

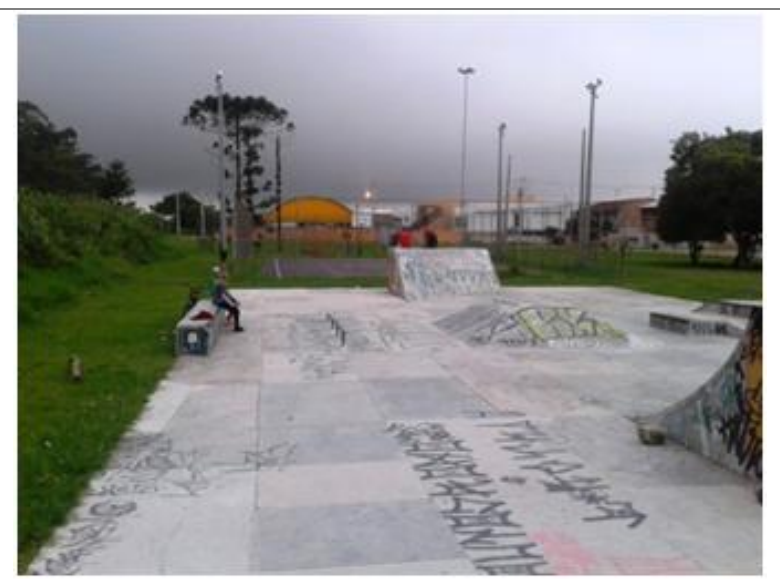

(b)

Figura 23 - Vista parcial dos equipamentos de uso público no Parque Linear Cajuru, Curitiba-PR: (a) aspecto parcial da quadra poliesportiva; (b) aspecto parcial da pista de skate. 
As áreas para descanso tais como bancos e equipamentos similares, estão bem distribuídas em todo o parque; não se visualizou em nenhum ponto bebedouros para os usuários, equipamento de extrema necessidade tendo em vista as dimensões do parque e os equipamentos destinados a atividades físicas.

Um fator que não consta como indicador na técnica proposta, mas que foi visualizado em todos os pontos é a iluminação pública, a qual é bem distribuída e ocorre em diferentes trechos. Tal infraestrutura é de extrema importância, uma vez que o parque funciona interruptamente e não existem formas de inibição de uso, a iluminação deixa a área menos suscetível a ações vandálicas em horários noturnos e a marginalização.

As variáveis que receberam a melhor pontuação para os indicadores de uso público foram: equipamentos de lazer, áreas para práticas esportivas e áreas para descanso, evidenciando-se maior atenção para o uso público. Ainda sim, fazem-se necessárias avaliações que tenham como foco a identificação da qualidade que estes equipamentos apresentam para a utilização (FIGURA 24).

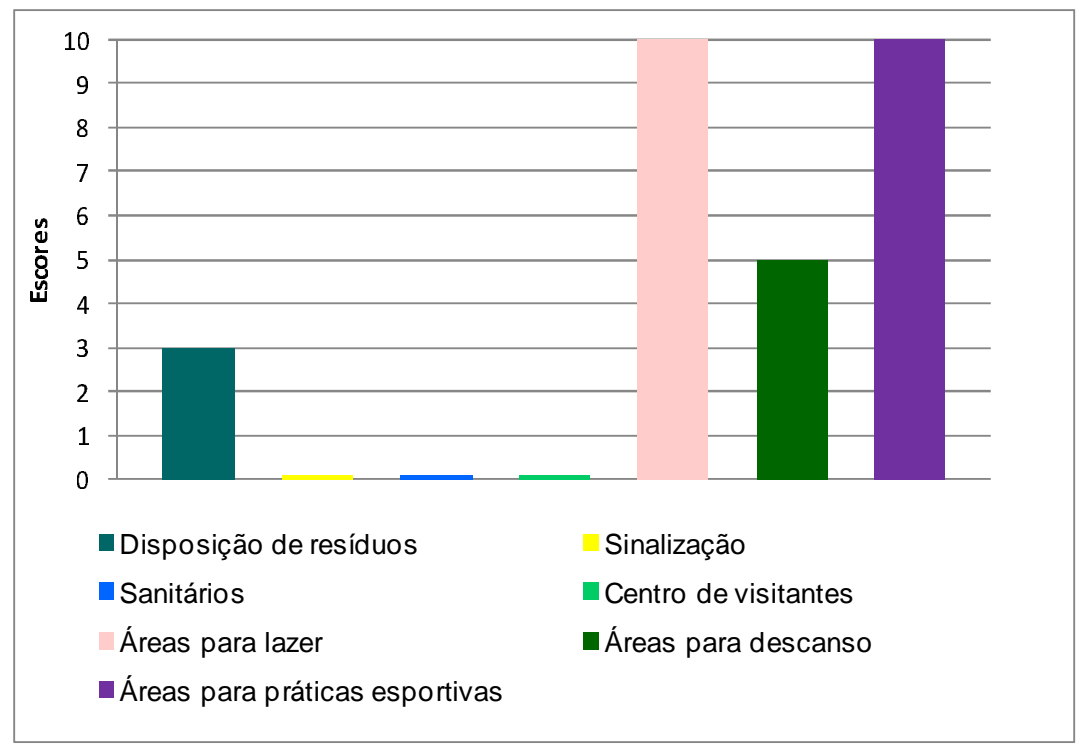

Figura 24 - Síntese gráfica dos escores atribuídos aos indicadores de uso público aplicados no Parque Linear Cajuru, Curitiba, Paraná.

O parque apresenta carência quanto à presença de sanitários, centro de visitantes e sinalização, não é possível identificar nem o nome do parque, bem como seus limites e informações sobre sua criação e implementação; enfatizando a necessidade de criação de um centro de visitantes. Também se destaca a necessidade da distribuição de lixeiras em toda sua extensão, com menores espaçamentos possíveis, pois, evidencia-se o acúmulo de resíduos descartados indevidamente sobre o solo. Tais fatores nos permite julgar que o parque cumpre 
moderadamente com a função de uso público, ou seja, verificam-se moderadas características que subsidiam o cumprimento da função social, aqui denominado de uso público.

Embasando-se nas informações supracitadas e de acordo com a ferramenta proposta, o Parque Linear do Cajuru, computou um IC de 4,7, indicando que a área cumpre moderadamente com as funções de conservação; e um IUP de 5,1 pontos, que também permite julgar que o parque cumpre de forma moderada com a função de uso público (TABELA 8).

Tabela 8 - Síntese dos indicadores de conservação e uso público e seus respectivos escores e índices no Parque Linear Cajuru, Curitiba, Paraná.

\begin{tabular}{|c|c|c|c|c|c|}
\hline Categoria & Indicador & $\begin{array}{l}\mathrm{E}_{\mathrm{a}}(\text { Escore } \\
\text { atribuído) }\end{array}$ & $\begin{array}{l}\text { Peso do } \\
\text { escore }\end{array}$ & $\begin{array}{l}E_{f}(\text { Escore } \\
\text { final })\end{array}$ & Índice \\
\hline \multirow{7}{*}{ Conservação } & Ocupação na margem hídrica & 5 & 3 & $\overline{1,5}$ & \multirow{7}{*}{4,7} \\
\hline & $\begin{array}{c}\text { Qualidade da vegetação (estrutura na } \\
\text { paisagem) }\end{array}$ & 2 & 2 & 0,4 & \\
\hline & Fragmentos florestais & 0 & 1 & 0 & \\
\hline & Curso hídrico & 8 & 1 & 0,8 & \\
\hline & Lançamento de esgoto sanitário & 10 & 1 & 1 & \\
\hline & Drenagem urbana & 10 & 1 & 1 & \\
\hline & Tipo de uso público & 0 & 1 & 0 & \\
\hline \multirow{7}{*}{ Uso Público } & Disposição de resíduos & 3 & 1 & 0,3 & \multirow{7}{*}{5,1} \\
\hline & Sinalização & 0 & 1,5 & 0 & \\
\hline & Sanitários & 0 & 1 & 0 & \\
\hline & Centro de visitantes & 0 & 1 & 0 & \\
\hline & Equipamento de lazer & 10 & 2 & 2 & \\
\hline & Áreas para descanso & 5 & 1,5 & 0,8 & \\
\hline & Áreas para práticas esportivas & 10 & 2 & 2 & \\
\hline
\end{tabular}

Assim, o Parque Linear Cajuru classificou-se como Moderada Equidade. De acordo com a metodologia proposta o Parque permite condições equitativas para manutenção dos aspectos naturais e uso público, necessitando de manejo tanto para as características naturais quantos para as características de uso público recreacional (FIGURA 25). 


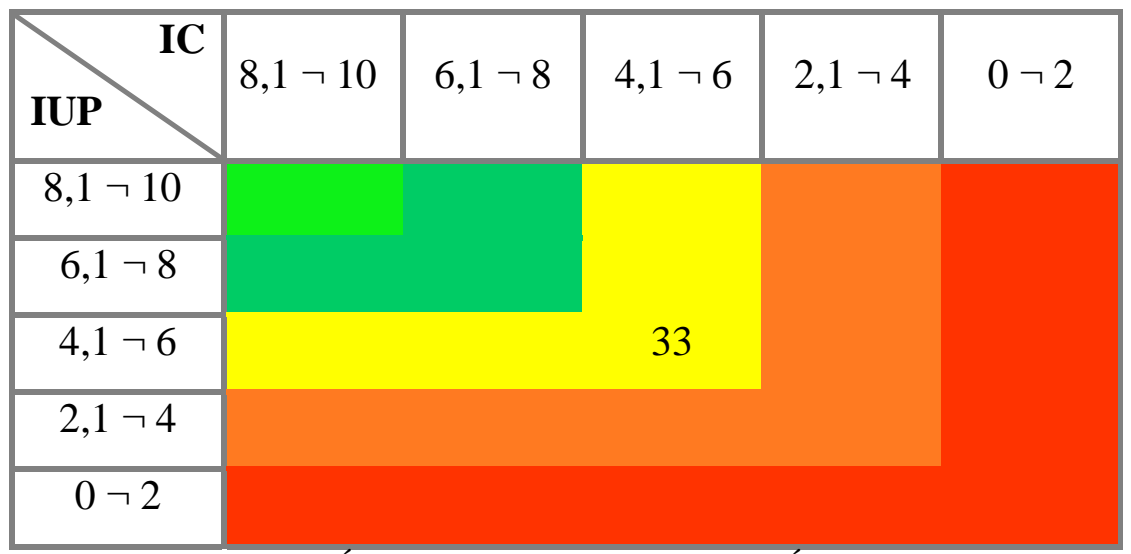

Figura 25 - Matriz de equidade entre o Índice de Conservação (IC) e o Índice de Uso Público no Parque Linear Cajuru, Curitiba-PR; em destaque na Linha 3 e Coluna 3 (33), a classificação do referido Parque Moderada Equidade.

\subsection{PARQUE PASSAÚNA}

O Parque Municipal do Passaúna localiza-se nos domínios da APA (Área de Proteção Ambiental) Estadual do Passaúna, a qual abrange os municípios de Araucária, Almirante Tamandaré, Campo Largo e Curitiba, totalizando 160,20 km². Esta Unidade de Conservação foi instituída pelo Decreto Estadual no 458/1991 e tem por objetivo, a proteção e a conservação da qualidade ambiental e dos sistemas naturais ali existentes, em especial a qualidade e quantidade da água para fins de abastecimento público, visto que, a APA abriga dois significativos mananciais: o manancial subterrâneo do Carste e o manancial superficial do Rio Passaúna. A APA Municipal, com $43 \mathrm{~km}^{2}$, abrange aproximadamente os mesmos limites a leste, dentro do município de Curitiba, da APA estadual. Compreende áreas do Parque Municipal de mesmo nome e localiza-se ao longo deste curso d'água. Criada pelo Decreto 80/1991, tem por objetivo proteger o manancial e o entorno do lago represado no Rio Passaúna e seus afluentes, garantindo a potabilidade da água para consumo humano. Seu nome deriva da palavra indígena apahuna que significa "homem negro" (ARAÚJO, 2007; CURITIBA, 2012; MÜLLER; OLIVEIRA; MOTTA, 2012).

O Parque de domínio Municipal insere-se na parte oeste de Curitiba, a aproximadamente $12 \mathrm{~km}$ do centro da cidade, na bacia hidrográfica do Rio Passaúna (ANEXO A), no bairro Augusta (ANEXO F). Os principais pontos de acesso localizam-se no final da Rua Eduardo Sprada, divisa com o Município de Campo Largo, e na Rua Angelo Marqueto (FIGURA 26).

A principal atração é o mirante de 12 metros de altura, localizado no alto de um morro à 
beira da represa, a 60 metros do nível do lago (FIGURA 27); trilha ecológica, com 3,5 km de extensão, junto ao lago e em meio ao bosque a qual percorre caminhos como pontes de madeira; recantos com churrasqueiras; ancoradouros para pescarias e acesso às antigas olarias, Totalizando uma área de $6.500 .000 \mathrm{~m}^{2}$ (ARAÚJO, 2007; CURITIBA, 2012; MÜLLER; OLIVEIRA; MOTTA, 2012).

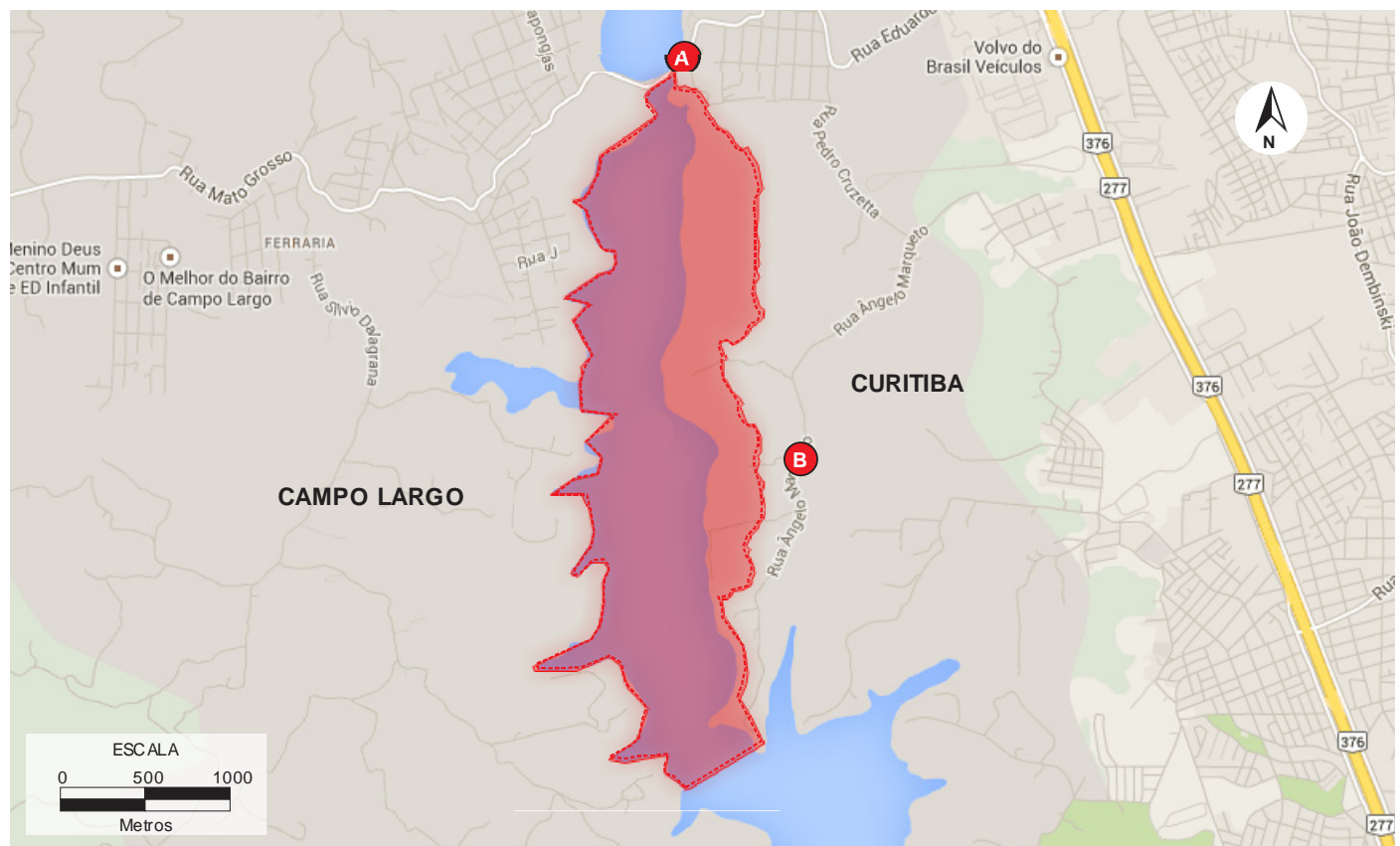

Figura 26 - Localização do Parque Municipal Passaúna, Curitiba, Paraná; em destaque na cor vermelha limites aproximados da área e localização dos portais de acesso: Ponto A - entrada no final da Rua Eduardo Sprada; Ponto B - entrada na Rua Angelo Marqueto.

Fonte: Adaptado de Google Earth, 2014.

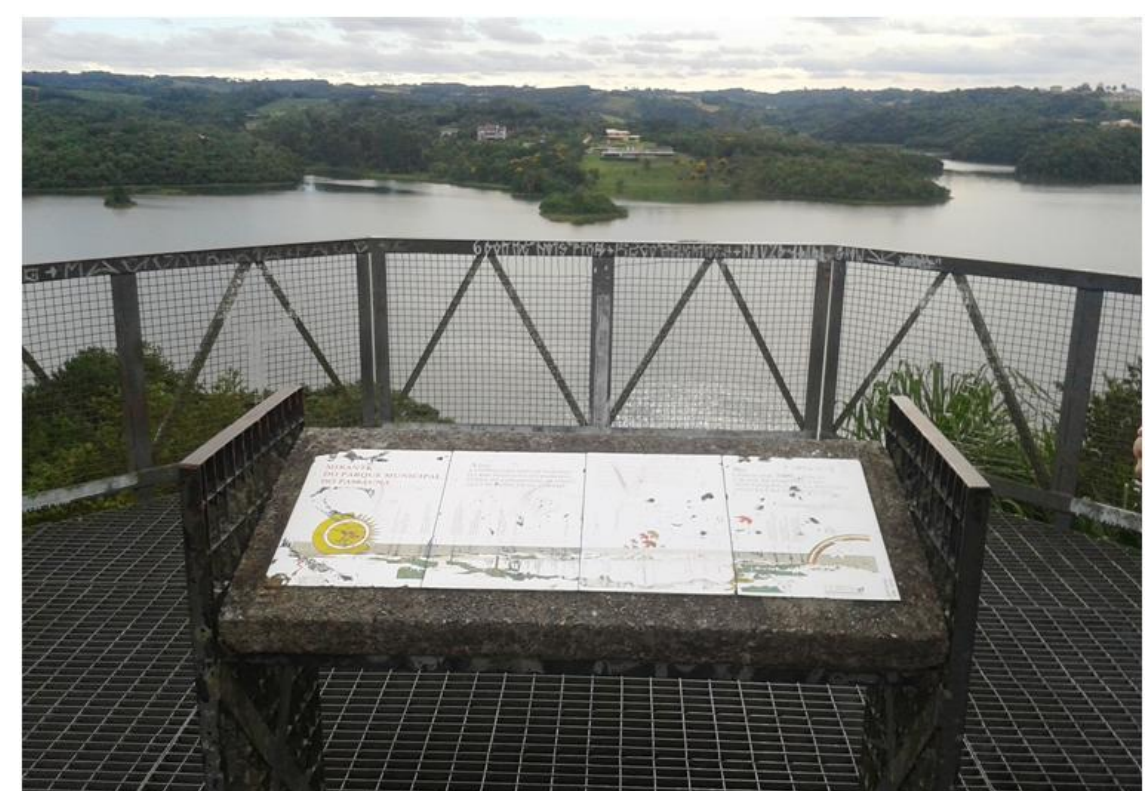

Figura 27 - Vista parcial do mirante para a represa e da placa sobre o histórico de inundação do parque Municipal Passaúna (Curitiba-PR). 


\subsubsection{Indicadores de Conservação}

O objetivo da aplicação dos indicadores de Conservação foi de identificar se parque permite condições para a manutenção das funções da estabilidade física e ecológica (Conservação).

Mais de 50\% das margens do Parque Passaúna estão ocupadas por vegetação ciliar, sendo poucas as áreas em que a população tem acesso direto por meio de equipamentos e infraestruturas de uso público. Ao percorre o parque nota-se que boa parte da margem é permeada por uma pista de uso compartilhado (pedestre/ciclista) que interliga os diferentes pontos de uso público, entretanto a vegetação ocorre em todos os pontos. Assim, para o quesito ocupação da margem hídrica o parque foi categorizado com a presença de vegetação ciliar (10 pontos).

Visto que em alguns trechos existem equipamentos recreacionais na margem, quiosques com churrasqueiras e pistas de caminhada, o parque foi classificado quanto à qualidade da vegetação como "Parcialmente contínua ao curso hídrico mais fragmentos florestais" (FIGURA 28).
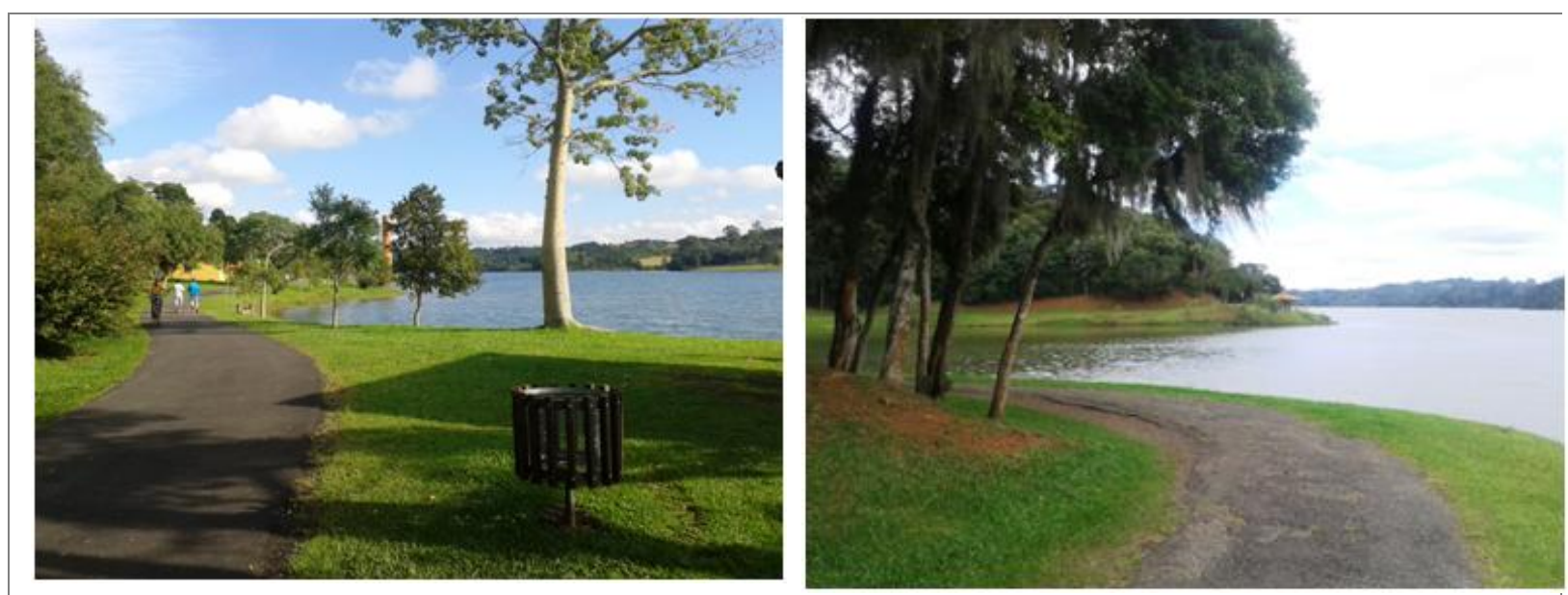

Figura 28 - Aspecto geral da pista de caminhada lindeira ao curso hídrico no Parque Municipal Passaúna, Curitiba, Paraná.

A vegetação apresenta ligação tanto com fragmentos internos, quanto com fragmentos externos. A Figura 29 apresenta os limites do parque, onde é possível notar fragmentos em toda a área limítrofe. Portanto se atribuiu a nota 10 - Ligação com fragmentos internos e externos. 


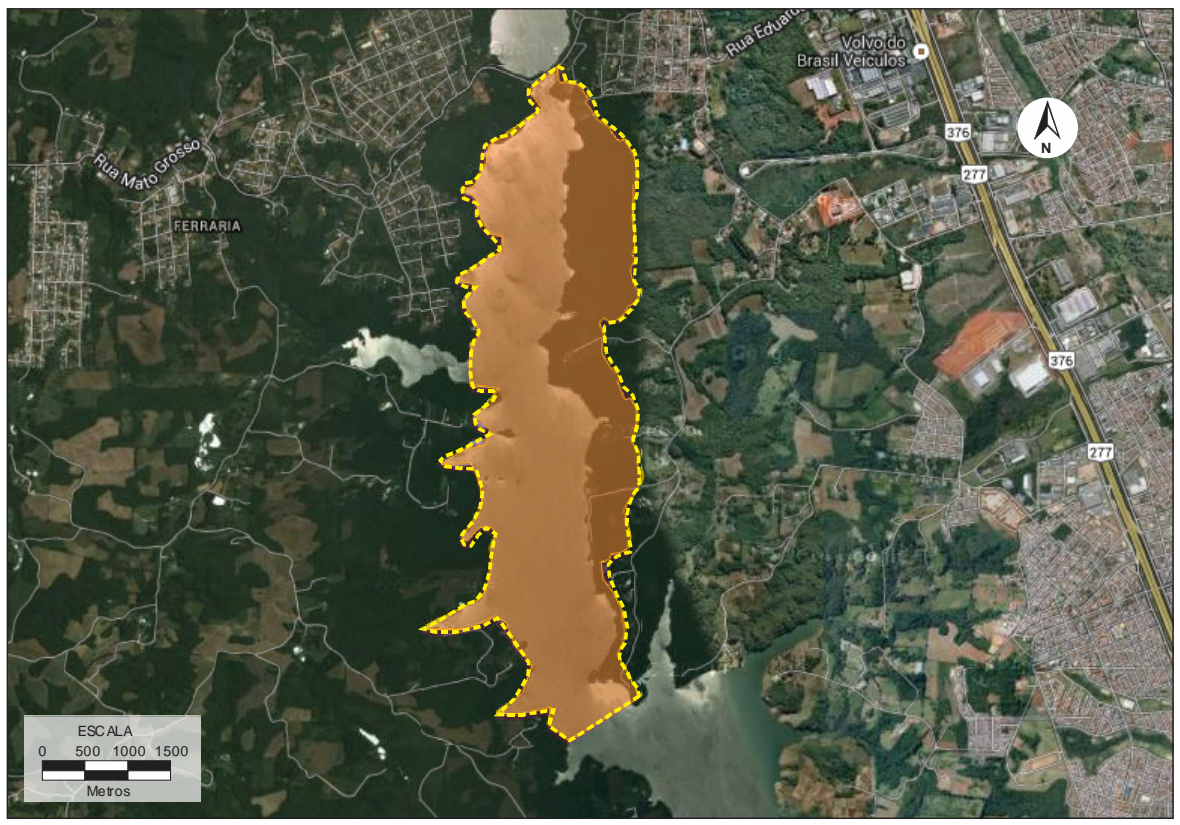

Figura 29 - Vista por satélite do Parque Municipal Passaúna (na cor amarela) em Curitiba (PR), e fragmentos de vegetação (identificados na cor verde) em seu entorno imediato.

Fonte: Adaptado de Google Earth, 2014.

De acordo com estudo realizado por SPVS (2009) e descrito por Müller, Oliveira e Motta (2012), o principal fragmento florestal da área possui $28.200 \mathrm{~m}^{2}$, está localizado no morro do mirante. Consiste em vegetação secundária, apresenta apenas dois estratos arbóreos - superior e inferior. O estrato herbáceo-arbustivo também está presente, no entanto é ralo e representado por um número reduzido de espécies. Nas bordas do fragmento há trechos de vegetação em sucessão secundária inicial arbustivo-arbórea (capoeirinha) e agrupamentos de Pinus sp.

Mielke (2012) ao realizar levantamento florístico com o intuito de identificar espécies exóticas invasoras em Parques Municipais de Curitiba, relatou a presença de apenas 17 indivíduos com status de exóticos invasor para a unidade fitogeográfica local em uma área de 26 hectares; número extremamente baixo quando comparado a outros parques da cidade, como o Parque Municipal Barrerinha, no qual foi constatado um incidente de 1373 indivíduos arbóreos com status de invasor em uma área de 12 hectares. Tais valores nos permitem inferir que além da boa distribuição da vegetação no Parque o mesmo apresenta qualidade quanto à composição.

O curso hídrico apresenta-se represado em todo o perímetro do Parque, atribuiu-se a nota 5 no quesito canal hídrico. Salvo que a represa consiste em um dos principais mananciais de abastecimento público da cidade de Curitiba, Araucária e Campo Largo, nos pontos onde são permitidos o acesso público verifica-se apenas drenagem natural, atribuiu-se a nota 10 
para o quesito drenagem urbana.

A que se destacar que após a construção da barragem do rio Passaúna, de 1985 a 1989, e o represamento da água da bacia hidrográfica, a partir de 09/1990, os sedimentos gerados na bacia passou a ser retido em grande parte no reservatório, dando início ao processo de assoreamento e consequente diminuição progressiva na capacidade de armazenamento e da sua vida útil (SAUNITI; FERNANDES; BITTENCOURT, 2004). Xavier (2005) identificou a presença de nutrientes no reservatório indicando que o mesmo encontra-se em vias de eutrofização. Nos pontos de acesso público não observar-se a presença de macrófitas (indicadora da presença de nutrientes no meio aquático e consequente processo de eutrofização).

Não verifica-se a ocorrência de descarte de esgotos sanitários em nenhum ponto da represa. Atribuiu-se ao quesito lançamento de esgoto sanitário a nota 10- Inexistente.

Apesar de não identificado pontos de lançamento de efluentes e nem pontos de drenagem de águas pluviais no perímetro analisado, Busch (2009) observou em sua pesquisa pontos de ligações clandestinas de esgotos domésticos na rede de água pluvial próximo as margens da represa na Vila São José (Bairros Augusta, Curitiba) e a referida autora também inferiu a presença de esgoto junto à rede de drenagem em outro ponto, ao coletar amostras de água com características de efluente doméstico, em um poço de visita localizado na parte mais baixa da Vila São José, a poucos metros da represa do Passaúna,

O parque enquadra-se no uso Indiscriminado I, pois apresenta horário de funcionamento pré-estabelecido. Devido à dinâmica, e tamanho da área, não é possível controlar a visitação, uma vez que em alguns pontos não existem gradeamento ou outro tipo de controle como câmeras de vigilância, como exemplo, na Rua Eduardo Sprada; na parte interna não se verifica restrições de acesso às áreas de vegetação fragmentos, caracterizando o Parque Passaúna como uso Indiscriminado I (3 pontos). Ainda ocorre nos domínios do parque uma base da Guarda Municipal. Porém, os fatores analisados não permitem fazer um julgamento da eficiência da respectiva força policial quanto às restrições de visitação.

Corroborando a ideia de falta de controle do uso público, Gonzaga et al. (2004) relatam que a trilha do parque é utilizada dia e noite por pessoas de todas as idades que fazem da pesca artesanal uma das principais atividades desenvolvidas em toda a sua extensão.

Os indicadores de caráter físico-natural (Conservação) que apresentaram melhores pontuações foram: ocupação à margem hídrica, fragmentos florestais, drenagem urbana e lançamento de esgotos sanitários. A maior parte das variáveis analisadas de caráter natural receberam pontuação acima de 5, com exceção do tipo de uso público, o qual recebeu apenas 
3 pontos. Tais fatores permitem que o parque propicie condições para a manutenção dos aspectos físicos e ecológicos (FIGURA 30).

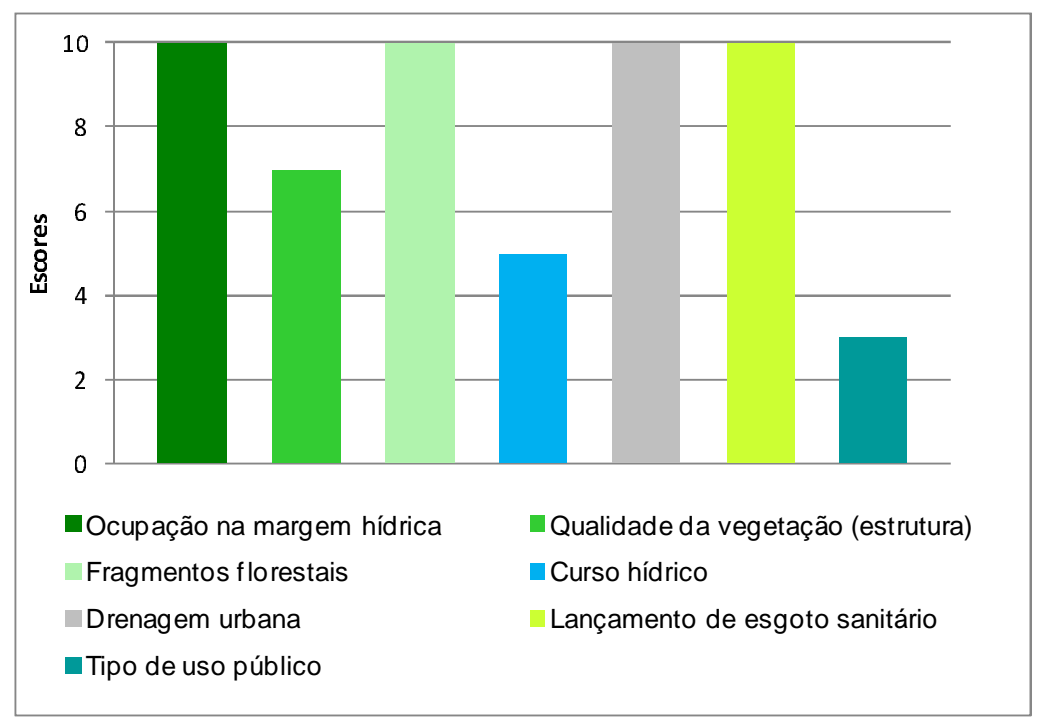

Figura 30 - Síntese gráfica dos escores atribuídos aos indicadores de conservação aplicados no Parque Municipal Passaúna, Curitiba, Paraná.

\subsubsection{Indicadores de Uso público}

Os indicadores de Uso público caracterizam os elementos necessários para subsidiar a manutenção das funções de uso público.

O parque conta com lixeiras bem espaçadas nos pontos de maior uso público, próximo a pistas de caminhadas e mobiliários de usos recreacionais. Não se evidencia as mesmas nas áreas de estacionamento, ou em outras áreas que aparentemente apresentam menor utilização; visto que as lixeiras encontram-se espaçadas em raios de menos de 100 metros nos pontos de uso mais intensivo, e espaçadas em raios de mais de 500 metros em pontos de menor utilização, atribuiu-se a nota 6 (FIGURA 31 e 32). 


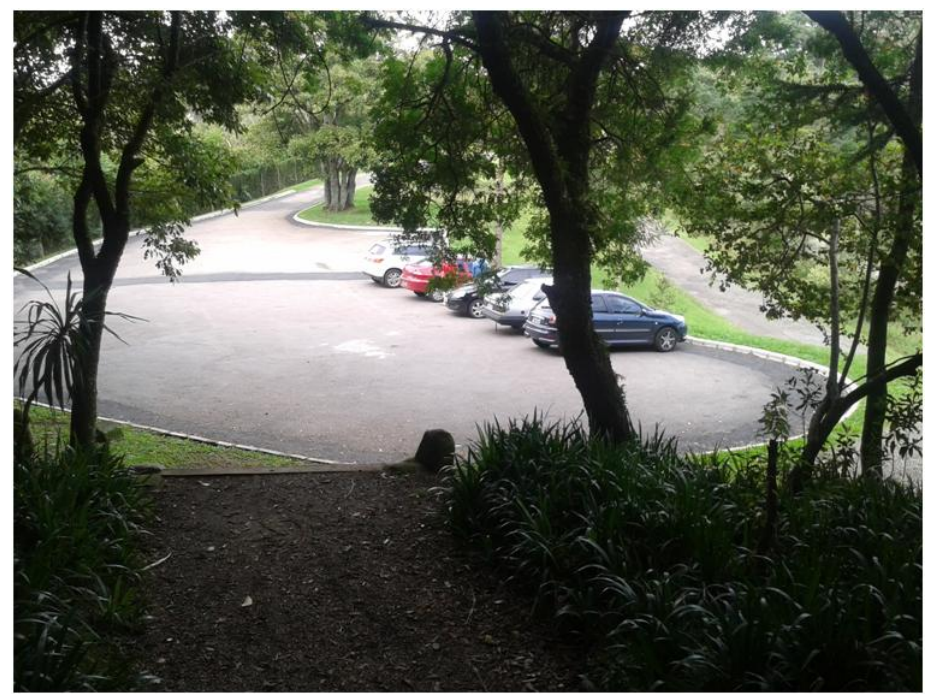

Figura 31 - Vista parcial da área de estacionamento próximo ao mirante no Parque Municipal Passaúna (Curitiba-PR), onde não se evidencia a presença de lixeiras.

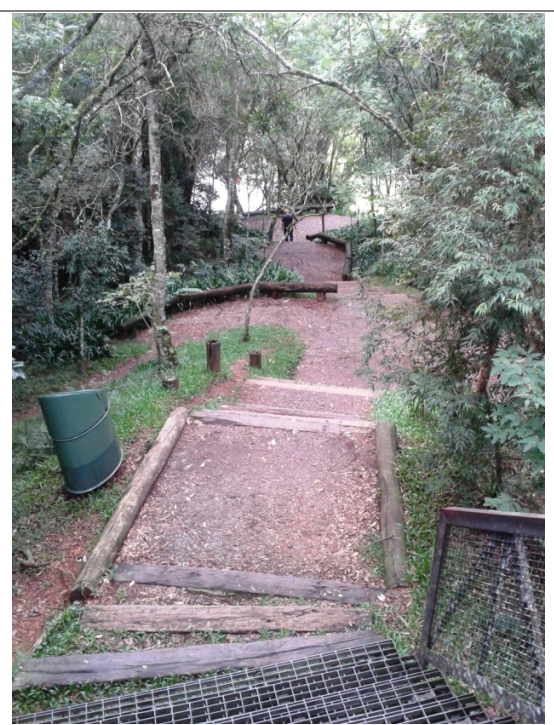

(a)

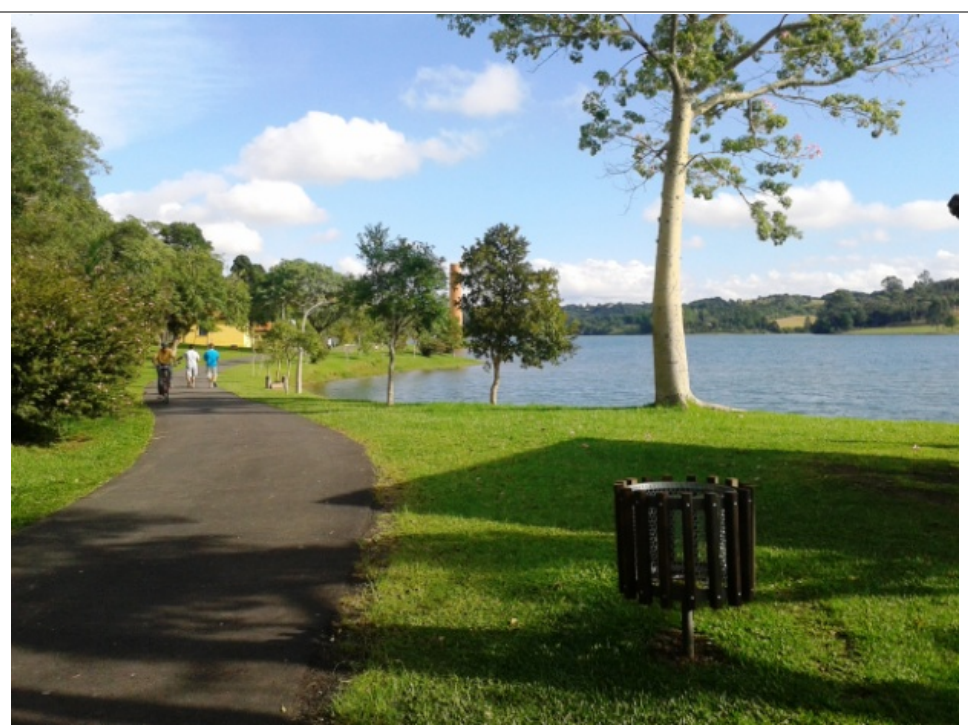

(b)

Figura 32 - Vista parcial da presença de lixeiras no Parque Municipal Passaúna (Curitiba-PR): (a) lixeira na trilha de acesso ao mirante; (b) lixeira próximo à pista de caminhada lindeira a represa.

Existem sinalizações nos principais pontos de acesso e em áreas de uso mais intenso como playgrounds. A sinalização é composta por placas de alertas e condutas de usuários, informações sobre o parque nos acessos principais (Rua Eduardo Sprada e Rua Angelo Marqueto) e sinalização no mirante com informações sobre o histórico de inundação da área. Apesar das placas serem distribuídas em todo o parque, ainda percebe-se a carência de sinalização principalmente no que diz respeito a informações sobre os atrativos de uso público para os visitantes, tais como informações sobre o mirante em diferentes pontos. Assim, atribuiu-se a nota 6 - presentes na entrada e pontos estratégicos, para tal quesito. A falta de sinalização permite que o público não explore todo o potencial do parque (FIGURA 33). 


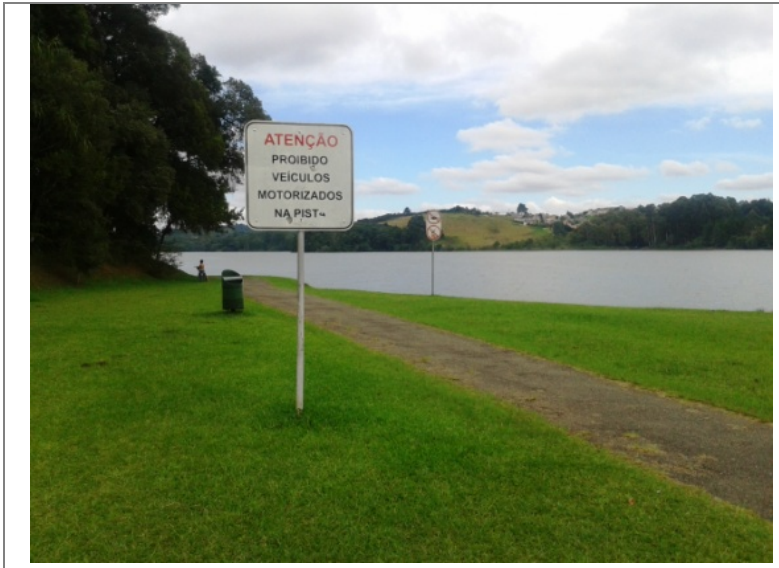

(a)

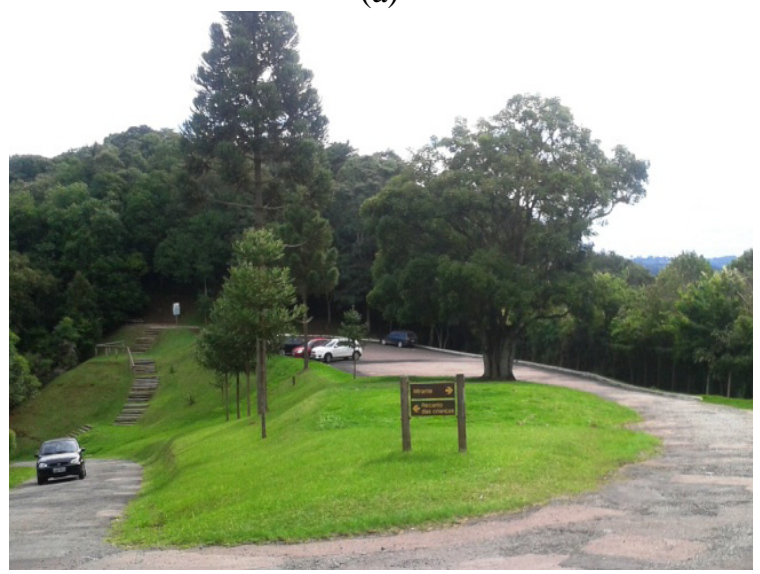

(c)

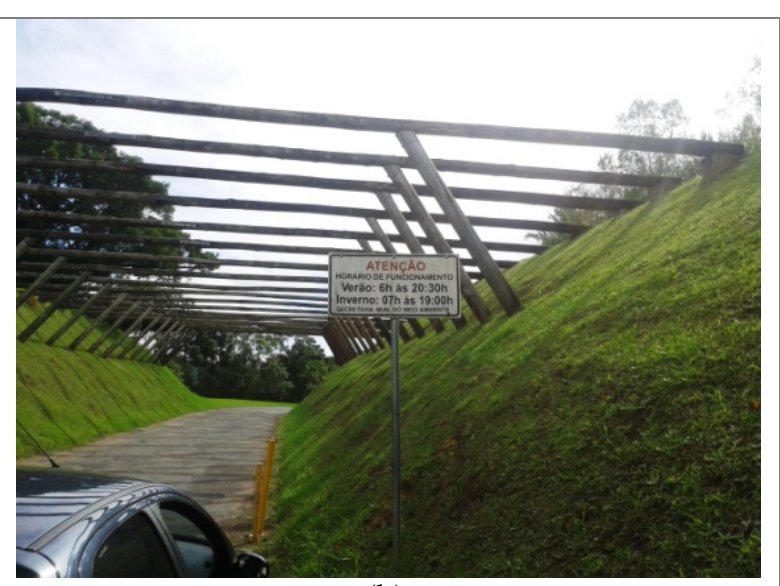

(b)

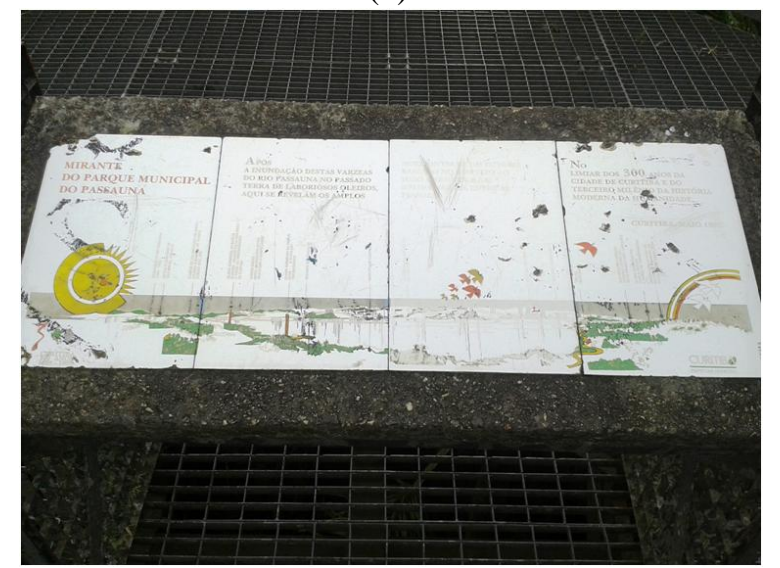

(d)

Figura 33 - Vista parcial de Sinalização no Parque Municipal Passaúna (Curitiba-PR): (a) placa de alerta para conduta de usuários, próximo à pista de caminhada e a represa; (b) placa com informações referentes aos horários de visitação no portal de acesso da Rua Angelo Marqueto; (c) área de estacionamento com sinalização sobre o mirante e área de recreação infantil; e (d) sinalização no mirante sobre o histórico de inundação.

O Parque conta com sanitários privados instalados em uma propriedade ao lado de uma lanchonete que faz divisa junto ao parque, o qual cobra para utilização, e sanitários públicos próximos à área de recreação. Durante coletas realizadas aos finais de semana, o sanitário público não estava disponível aos usuários (FIGURA 34).

Não existe área para Centro de Visitantes ou espaço similar destinado à recepção para os usuários e atividades de Educação Ambiental. Faz-se necessário a presença de um espaço para este fim, o qual contemple histórico da área e propicie palestras, pois é de fundamental importância, tendo em vista a potencialidade paisagística, ecológica, social e educacional da área. Atribui-se a tal indicador a nota 0 (zero) - Inexistente.

Existem equipamentos de lazer como playgrounds, pista de caminhada, quiosques com churrasqueiras e a utilização da represa para atividades náuticas como caiaquismo, além de trilhas de interpretação ambiental. Não são permitidas atividades de nado ou outras de contato direto na represa, mas, corriqueiramente verificam-se visitantes banhando-se. Em virtude dos 
equipamentos disponíveis para a utilização dos usuários para práticas esportivas e recreação e lazer, atribuiu-se a nota 10 para ambos os quesitos (FIGURA 35).

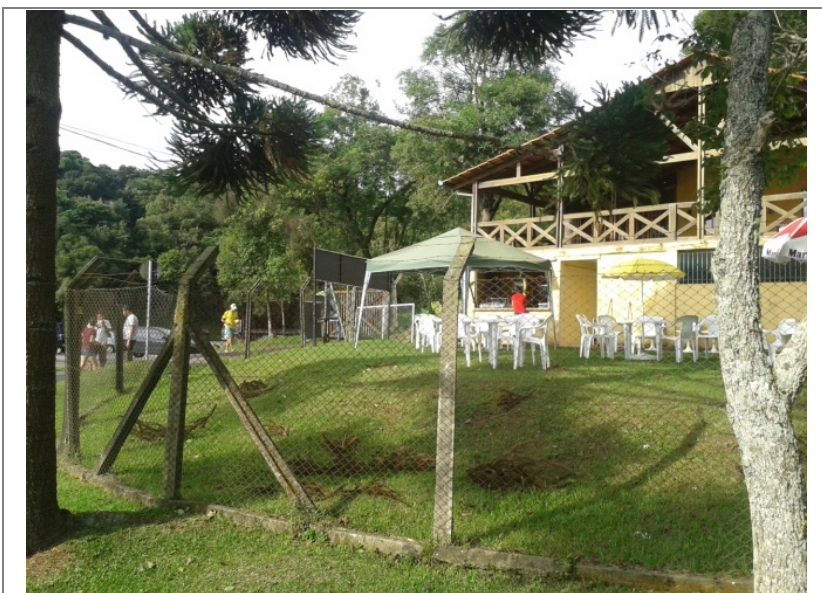

(a)

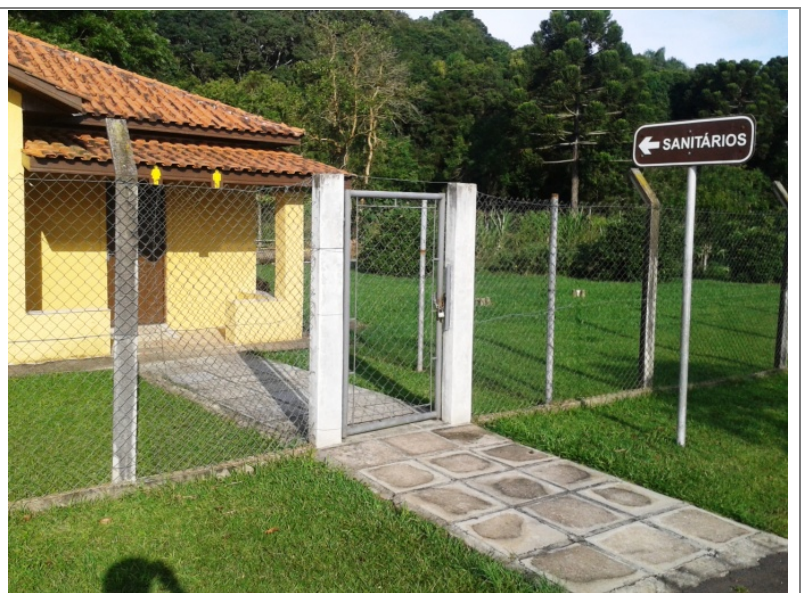

(b)

Figura 34 - Vista parcial dos sanitários nas dependências do Parque Municipal Passaúna (Curitiba-PR): (a) lanchonete e sanitários em propriedade particular; (b) sanitário público.

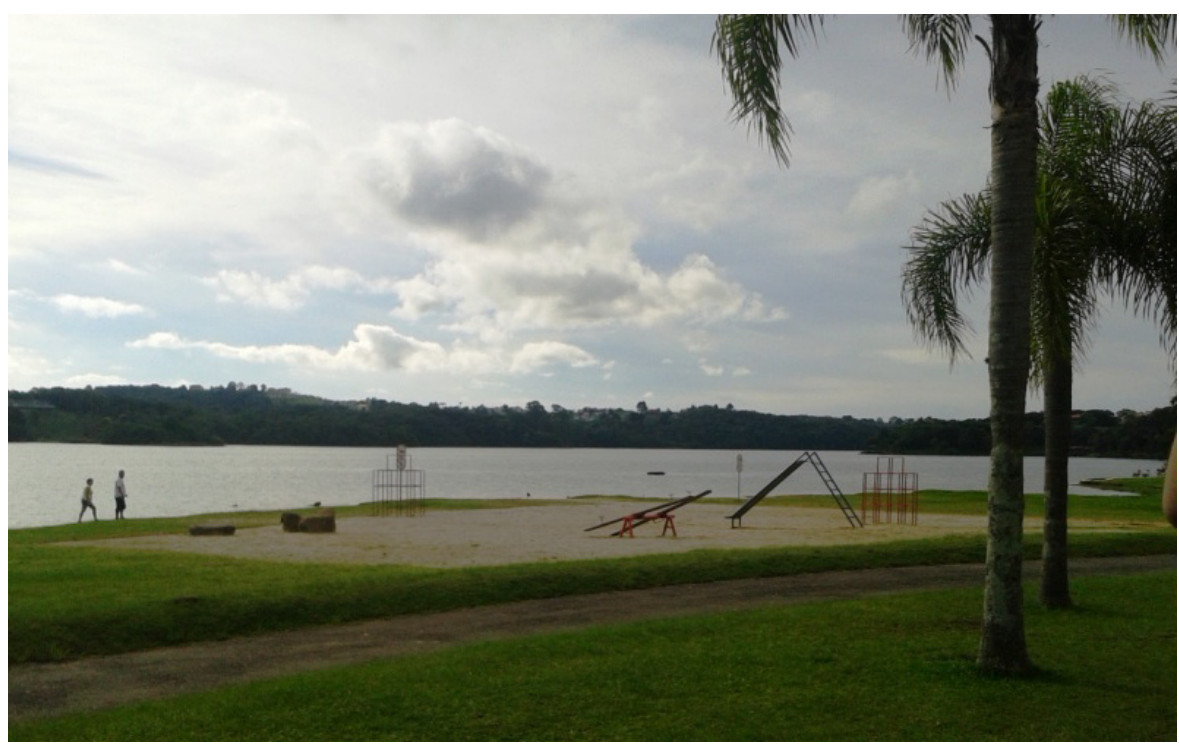

Figura 35 - Vista parcial da área para recreação infantil, no Parque Municipal Passaúna (Curitiba-PR).

De acordo com Machado et al. (2013) o reservatório no trecho do parque enquadra-se como Classe II de acordo com a Resolução Conama $n^{\circ} 357 / 2005$, onde são permitidos os seguintes usos múltiplos: Abastecimento Humano; Pesca Amadora; Dessedentação Animal; Recreação de Contato Secundário; e Harmonia Paisagística. As melhores classificações da bacia hidrográfica do Passaúna encontram-se no trecho entre a nascente e a barragem, a qual corresponde à área com melhor uso e ocupação do solo.

Como supracitadas anteriormente, práticas de contato direto, como o nado são proibidas e advertidas por meio de sinalização. A classificação do corpo hídrico implica que a água é 
inapropriada para tal uso, devido suas características físico-químicas e microbiológicas, podendo afetar diretamente a saúde das populações que se permitem a tal uso.

O Parque conta com áreas para descanso equipadas com bancos, comumente próximos a espaços arborizados, o que permite melhor conforto térmico para os usuários; não identificouse bebedouros em nenhum ponto. Atribuiu-se a nota 5 (cinco) para a variável "áreas para descanso".

Os indicadores de caráter de uso público que receberam as menores classificações foram: centro de visitantes, uso público e áreas para descanso, respectivamente, 0, 3 e 5. Os indicadores que apresentaram maiores escores foram: sanitários, equipamentos de lazer e áreas para práticas esportivas (FIGURA 36).

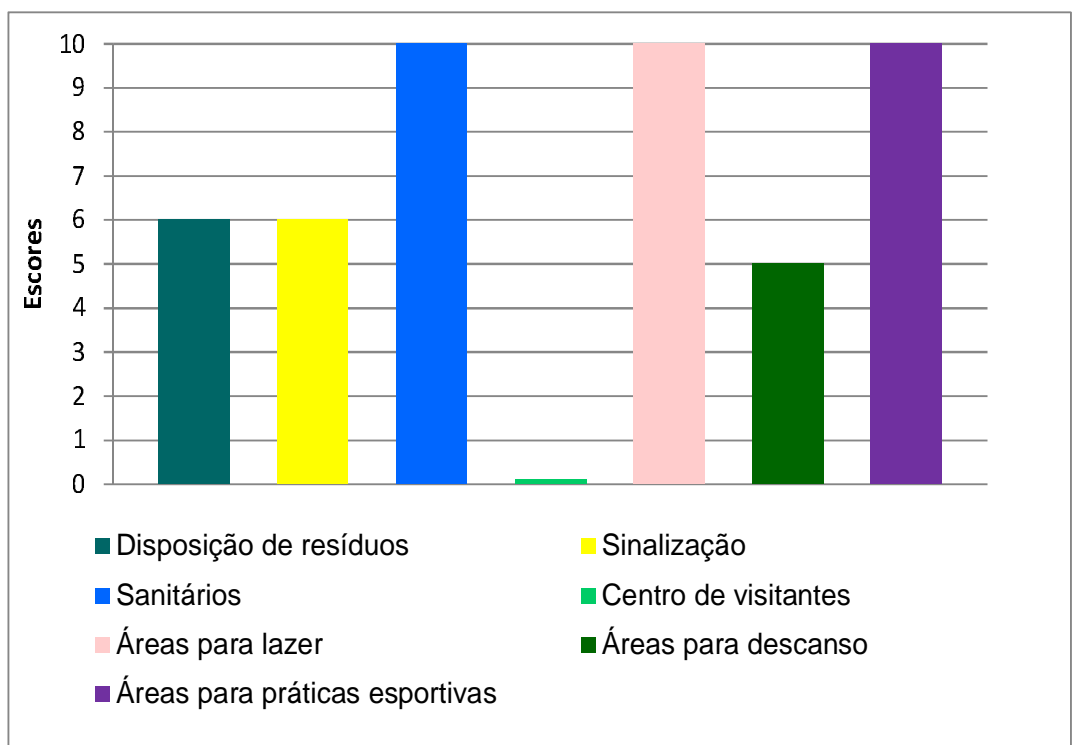

Figura 36 - Síntese gráfica dos escores atribuídos aos indicadores de uso público aplicados no Parque Linear Cajuru, Curitiba, Paraná.

De acordo com as variáveis analisadas o Parque apresenta a um IC de 8,2, o que permite julgar que o parque apresenta elementos necessários para a manutenção dos aspectos físicos e ecológicos, e assim cumpre com suas funções de conservação. E um IUP de 7,3 que nos indica que, o parque é constituído de elementos que fomentam o uso público, permitindo que o parque cumpra com as funções de Uso Público (FIGURA 37; TABELA 9).

Assim, segundo a matriz de equidade, infere-se que o parque apresenta conciliação entre o Uso Público e a Conservação (FIGURA 38). 


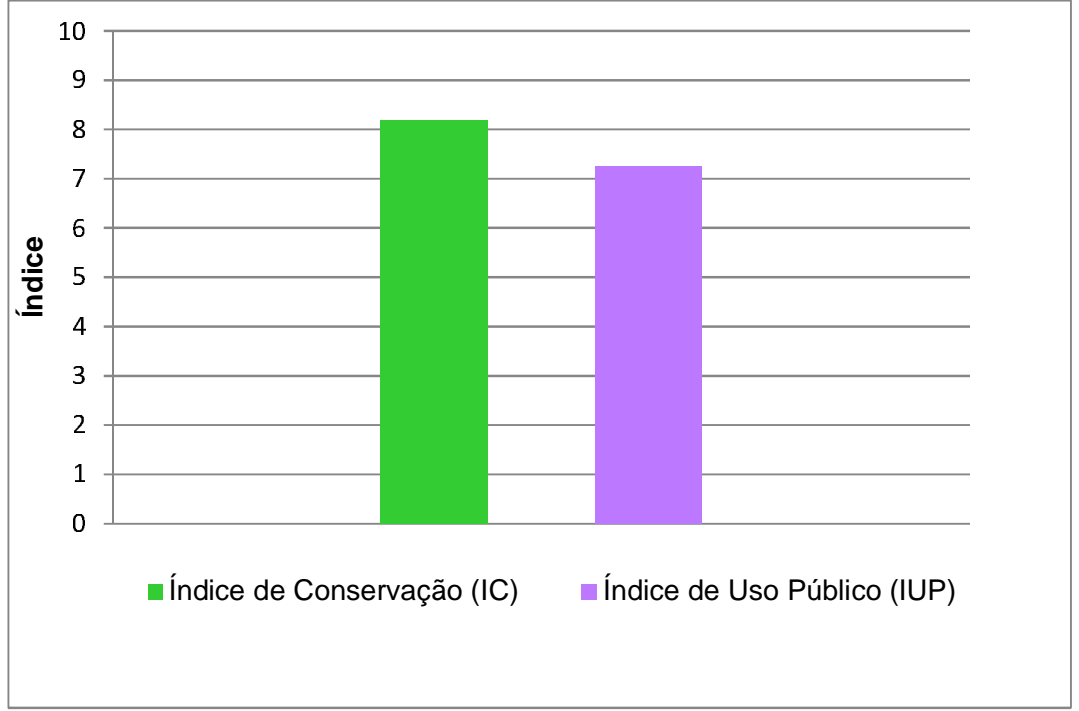

Figura 37 - Síntese gráfica do Índice de Conservação (IC) x Índice de Uso Público (IUP) no Parque Municipal Passaúna, Curitiba-PR.

Tabela 9 - Síntese dos indicadores de conservação e uso público e suas respectivas pontuações e índices no Parque Municipal Passaúna, Curitiba, Paraná.

\begin{tabular}{|c|c|c|c|c|c|}
\hline Categoria & Indicador & $\begin{array}{l}\mathbf{E}_{\mathbf{a}}(\text { Escore } \\
\text { atribuído) }\end{array}$ & $\begin{array}{l}\text { Peso do } \\
\text { escore }\end{array}$ & $\begin{array}{l}\mathbf{E}_{\mathrm{f}}(\text { Escore } \\
\text { final) }\end{array}$ & Índice \\
\hline \multirow{7}{*}{ Conservação } & Ocupação na margem hídrica & 10 & 3 & 3 & \multirow{7}{*}{8,2} \\
\hline & $\begin{array}{c}\text { Qualidade da vegetação (estrutura na } \\
\text { paisagem) }\end{array}$ & 7 & 2 & 1,4 & \\
\hline & Fragmentos florestais & 10 & 1 & 1 & \\
\hline & Curso hídrico & 5 & 1 & 0,5 & \\
\hline & Lançamento de esgoto sanitário & 10 & 1 & 1 & \\
\hline & Drenagem urbana & 10 & 1 & 1 & \\
\hline & Tipo de uso público & 3 & 1 & 0,3 & \\
\hline \multirow{7}{*}{ Uso Público } & Disposição de resíduos & 6 & 1 & 0,6 & \multirow{7}{*}{7,3} \\
\hline & Sinalização & 6 & 1,5 & 0,9 & \\
\hline & Sanitários & 10 & 1 & 1 & \\
\hline & Centro de visitantes & 0 & 1 & 0 & \\
\hline & Equipamento de lazer & 10 & 2 & 2 & \\
\hline & Áreas para descanso & 5 & 1,5 & 0,8 & \\
\hline & Áreas para práticas esportivas & 10 & 2 & 2 & \\
\hline
\end{tabular}




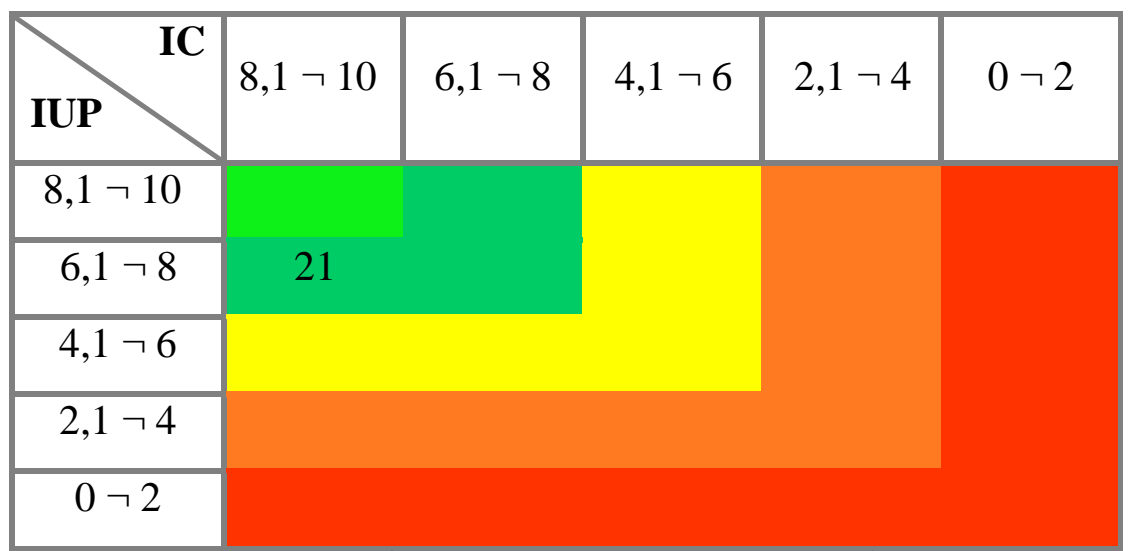

Figura 38 - Matriz de equidade entre o Índice de Conservação (IC) e o Índice de Uso Público no Parque Municipal Passaúna, Curitiba-PR; em destaque na Coluna 2 e Linha 1 (21), a classificação do referido Parque - Boa Equidade.

\subsection{ANÁLISE COMPARATIVA ENTRE OS PARQUES}

A título de comparação, frente aos aspectos de físico-naturais, o Parque Nascentes do Belém apresenta os melhores Índices de Conservação (IC), seguido pelo Parque Passaúna e Linear Cajuru, respectivamente 9.6, 8.2 e 4.7. Quanto aos Índices de Uso Público (IUP), o Parque Passaúna apresenta os melhores resultados, seguido pelo Parque Cajuru, 7.3 e 5.1 respectivamente; o Parque Nascentes do Belém apresentou o IUP de 2,7, onde foi verificado condições abaixo do desejável para um parque em ambiente urbano, devido à insuficiência de equipamentos e infraestruturas destinadas a população (FIGURA 39).

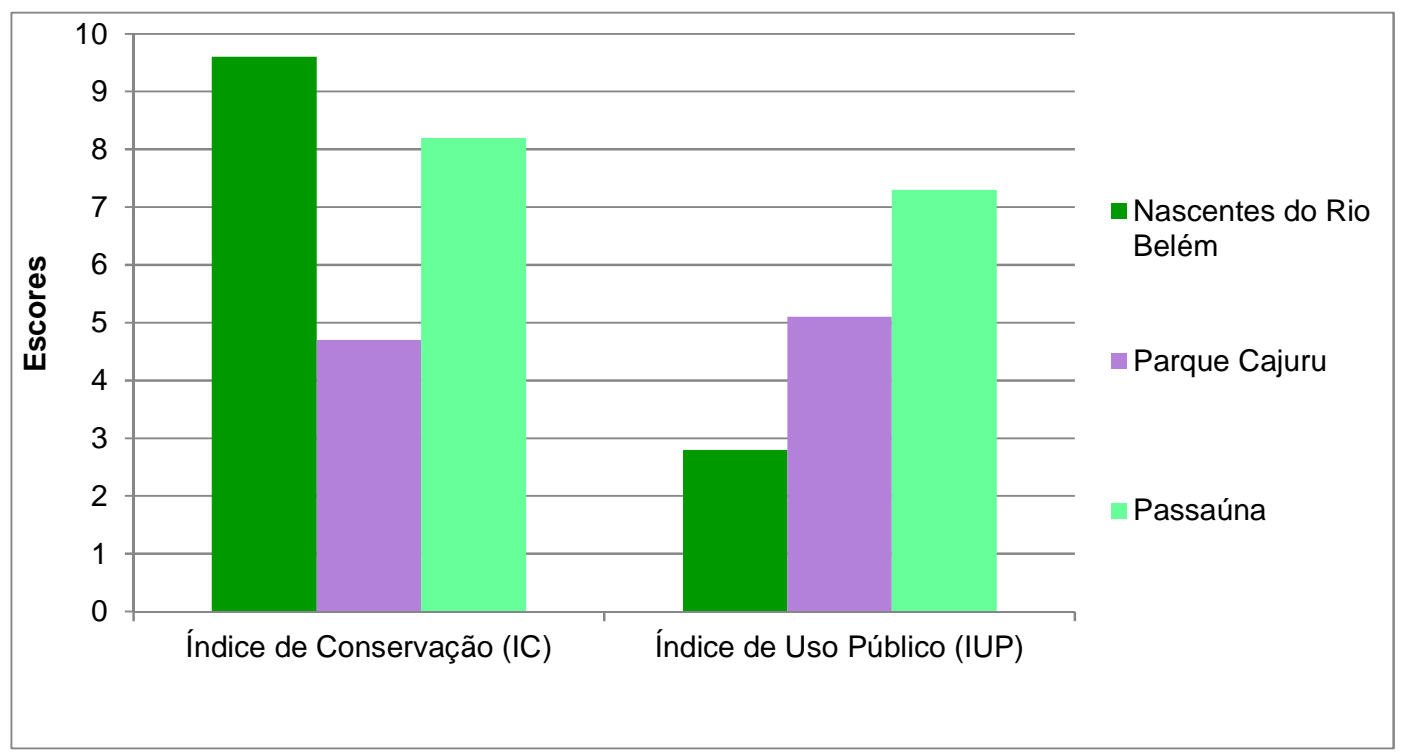

Figura 39 - Síntese dos Índices de Conservação e de Uso Público nos Parques Municipais: Nascentes do Belém, Cajuru e Passaúna, em Curitiba Paraná. 
Frente a tais resultados, há que se julgar os critérios de formação de cada área: o nascentes do Belém teve como intuito a conservação das nascentes, para tal, toda área foi reflorestada; o Passaúna visa melhor ocupação do uso da terra para assegurar água em quantidade e qualidade às populações humanas, assim um dos principais critérios para assegurar a qualidade é a manutenção da vegetação ciliar; já o parque Cajuru advém de uma área totalmente degradada, a qual era ocupada por moradias irregulares sujeitas a inundações periódicas, após a desapropriação a área foi reflorestada, mas com o intuito e assegurar que esta área não fosse ocupada novamente o principal foco foi disponibilizar equipamentos de lazer e recreação em abundância para as populações circunvizinhas, aparentemente não houve acompanhamento do plantio da arborização nas margens, além do parque localizar-se em um bairro de alta densidade demográfica quando comparado com os demais parques (TABELA 10), fator que permite que a área sofra maior pressão por uso público.

Tabela 10 - Relação da densidade demográfica por bairros dos Parques analisados em Curitiba, Paraná.

\begin{tabular}{ccccc}
\hline Parque & Bairro & População & Área $\left(\mathbf{k m}^{2}\right)$ & Densidade $\left(\mathbf{h a b} / \mathbf{k m}^{2}\right)$ \\
\hline Nasc. Belém & Cachoeira & 9.314 & 3,22 & $2.892,55$ \\
Cajuru & Cajuru & 96.200 & 11,79 & $8.159,46$ \\
Passaúna & Augusta & 6.598 & 9,17 & 719,52 \\
\hline Cidade & Curitiba & $\mathbf{1 . 7 5 1 , 9 1}$ & $\mathbf{4 3 4 , 8 1}$ & $\mathbf{4 , 0 2 9 , 1 3}$ \\
\hline
\end{tabular}

Fonte: IPPUC, 2013.

Ao analisar os Indicadores de Conservação individualmente, o Parque Nascentes do Belém propicia as melhores condições para a manutenção dos aspectos naturais, apresentando elevada discrepância quando comparado ao Parque Linear Cajuru, o qual obteve os menores índice, abaixo de 5 pontos, nos quesitos ocupação da margem hídrica e qualidade e estrutura da vegetação na paisagem. O parque Passaúna apresenta as maiores pontuações, nos quesitos analisados referentes à conservação. Ainda ressalta-se que próximo ao Parque Passaúna ocorre os maiores fragmentos florestais e também consiste na área com menor densidade demográfica, além de localizar-se em uma Unidade de Conservação maior, a APA Estadual do Passaúna.

A drenagem urbana e o lançamento de esgotos sanitários foram os indicadores que receberam os maiores escores (nota 10) em todos os parques; no item ocupação da margem hídrica e fragmentos florestais os parques, Belém e Passaúna receberam nota a 10; o Parque Cajuru foi à única área a receber nota 0 para ligação, ou seja, não apresenta nenhum tipo de fragmento nas áreas adjacentes, tal fator esta intrinsecamente relacionado à intensa 
urbanização e alta densidade demográfica em seu entorno (FIGURA 41).

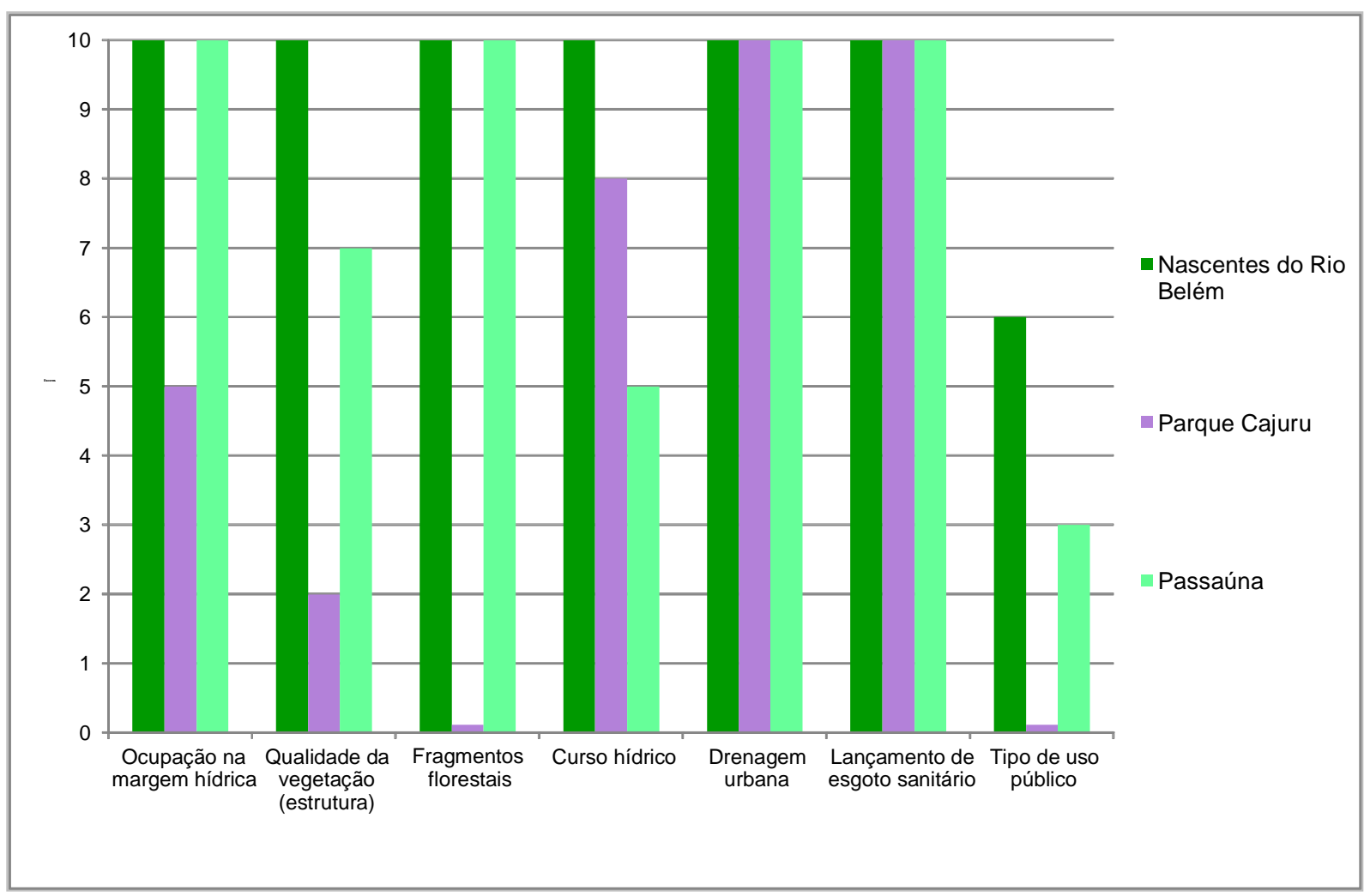

Figura 40 - Relação dos escores atribuídos aos indicadores de conservação nos Parques Municipais: Nascentes do Belém, Passaúna e Cajuru, em Curitiba, Paraná.

Para todas as áreas analisadas, foram atribuídos o escore 0 (zero) para o indicador “centro de visitantes", visto que nenhuma das unidades possuíam estruturas ativas com tal finalidade.

O Passaúna corresponde ao parque com as melhores condições para as atividades de uso público; disponibiliza para seus usuários equipamentos e infraestrutura para lazer e recreação, sanitários, sinalização e áreas para descanso, entre outros. O parque Cajuru apresenta a melhor distribuição de equipamentos e infraestruturas para os visitantes; os equipamentos recreacionais são evidenciados em todo o perímetro do parque. O Nascentes do Belém não apresenta equipamentos de uso público intensivo, é interessante salientar que durante a visitação para coleta de dados não se identificou usuários, fator que permite que o parque deixe de cumprir com sua função social (FIGURA 41).

Quanto à conciliação entre o Uso Público e a Conservação, segundo o protocolo de campo, o Parque Passaúna apresentou as melhores condições para a manutenção de tais funções, ou seja, equidade entre os elementos que propiciam tais usos; o parque Linear Cajuru apresenta condições moderadas entre os usos recreacionais e de conservação; e o Parque 
Nascentes do Belém permite condições de baixa equidade entre os usos, devido à discrepância entre a conservação e o uso público. É interessante salientar que em um primeiro momento, tem-se a impressão que o Nascentes do Belém, permitiria condições no mínimo moderadas, entre os usos supramencionados, ideia inicial que é refutada embasando-se nos parâmetros analisados (QUADRO 4).

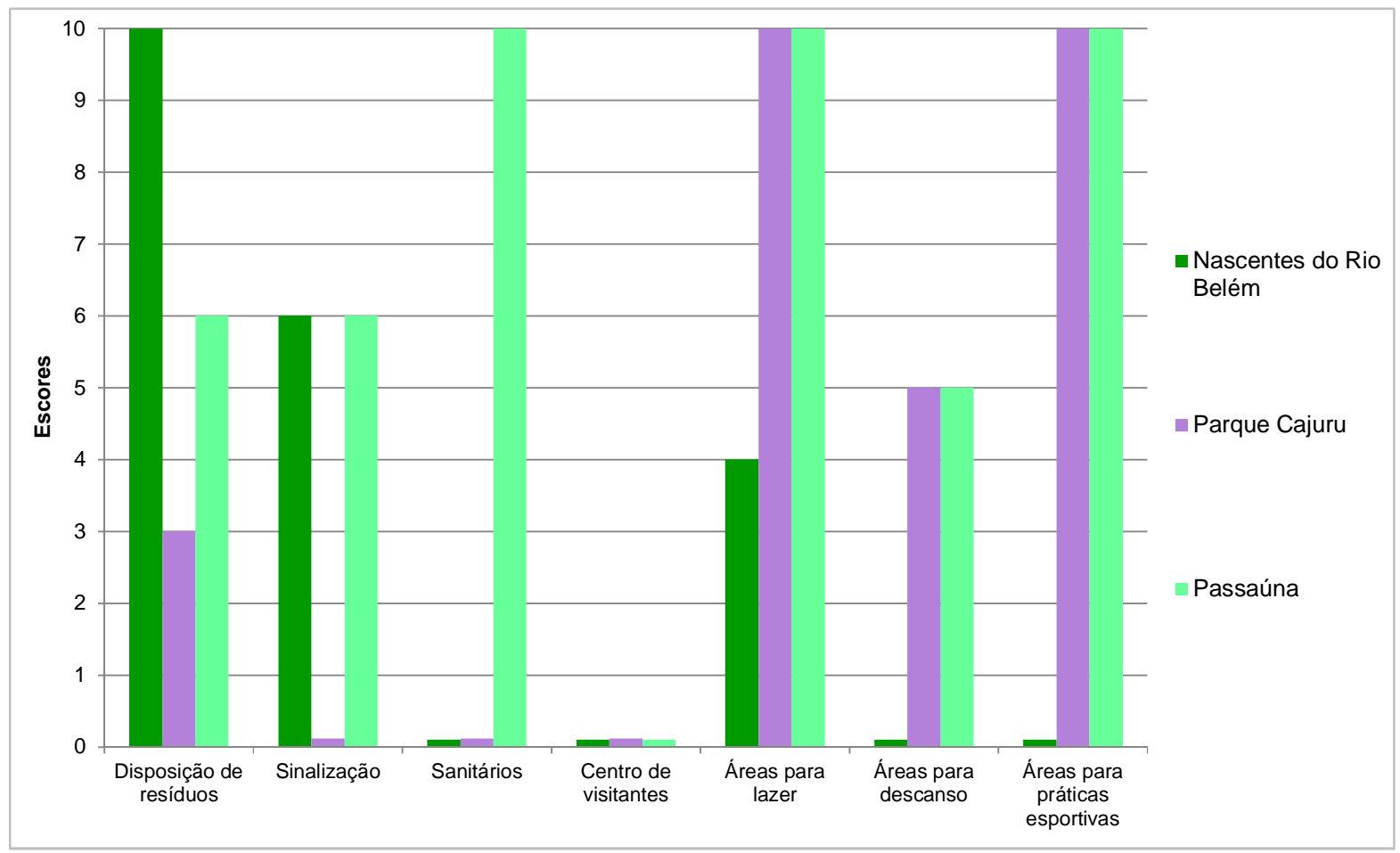

Figura 41 - Relação dos escores atribuídos aos indicadores de Uso Público nos Parques Municipais: Nascentes do Belém, Passaúna e Cajuru, em Curitiba, Paraná.

Quadro 4 - Classificação dos Parques Municipais analisados em Curitiba-PR, quanto ao equidade/conciliação entre as funções de Conservação e Uso Público.

\begin{tabular}{|c|c|c|c|}
\hline Status & Nascentes do Rio Belém & Passaúna & Parque Linear Cajuru \\
\hline Alta Equidade & & & \\
\hline Boa Equidade & & $\mathrm{X}$ & \\
\hline Moderada Equidade & & & $\mathrm{X}$ \\
\hline Baixa Equidade & $\mathrm{X}$ & & \\
\hline Inexistente & & & \\
\hline
\end{tabular}

\subsection{MEDIDAS NORTEADORAS A GESTÃO DOS PARQUES ANALISADOS}

Embasando-se nos dados analisados, é possível inferir medidas que subsidiem a gestão das unidades trabalhadas. Esta seção tem por objetivo tecer algumas considerações e apontar 
elementos que necessitem de manejo nos parques.

\subsubsection{Parque Municipal Nascentes do Belém}

Dentre as unidades analisadas o parque Nascentes do Belém, propicia as melhores condições para a manutenção dos aspectos físicos ecológicos. Entretanto, falha no quesito função social, uma vez que são poucas as infraestruturas destinadas ao uso público, além de não existirem equipamentos recreacionais desejáveis para um parque em malha urbana. A interação da população local com o parque é de suma importância, pois parte-se da premissa que o homem conserva aquilo que é de seu conhecimento, se não há interação direta da população este ambiente pode ser considerado uma área estanque do contexto da urbe, tornando-se suscetível a depredação e marginalização.

Embasando-se nos dados analisados são possíveis propor as seguintes medidas para gestão:

- Equipamentos de uso comunitário: a instalação de mobiliários de uso público deve ser precedida de uma investigação referente às aspirações da comunidade local; identificar a faixa etária da população do bairro; levantamento dos parques nas proximidades que já ofereçam atrativos de recreação e lazer, com o objetivo de disponibilizar elementos diferenciados, para então compor equipamentos que possam servir constantemente a essa população. Ainda sim, destaca-se que o parque não pode perder sua principal finalidade, a de CONSERVAR as nascentes do Rio Belém, então os potenciais equipamentos instalados não devem atrair a utilização em massa, mas sim a utilização constante.

- Centro de Visitantes: o Parque possui infraestrutura destinada a este fim, mas atualmente este ambiente é destinado à ocupação do CRAS; sugere-se a reapropriação deste espaço para atividades lúdicas e de Educação Ambiental (EA) e ilustração histórica da área. Parte-se do pressuposto que os dias de maior visitação nos parques urbanos são os finais de semanas, portanto, o Centro de Visitantes deverá funcionar principalmente nesses dias. As atividades de EA desenvolvidas devem ser prioritariamente relacionadas com o foco de conservação (nascentes urbanas), tais como: vegetação ciliar urbana; qualidade de águas urbanas; ocupação do solo urbano e sua influência na qualidade de água; qualidade de água em rios urbanos; fauna em fragmentos florestais urbanos; recuperação de áreas degradas 
urbanas, dentre outras atividades relacionadas às necessidades e histórico da unidade.

Pesquisa realizada por Zafalon e Silva (2012) corroboram os dados levantados em campo e a ideia de que a área não se utiliza de suas potencialidades. De acordo com a referida autora: segundo informações oficiais divulgadas pela Prefeitura Municipal em seu site, o parque conta com diversos equipamentos, como: marco, unidade de Educação Ambiental, sede de manutenção, sanitários, mirante, ponte, fonte, lago, estar/pergolado, caminhos e posto da Guarda Municipal, ao realizar uma visita técnica ao local constatou-se uma realidade diferente da idealizada no projeto, pois a construção que deveria ser destinada à Educação Ambiental, está sendo utilizada à aproximadamente cinco anos para a Fundação de Ação Social (FAS) do município; ao coletar informações com uma funcionária do parque a respeito do trabalho de educação ambiental, a mesma informou não saber do que se tratava, que apenas o órgão responsável teria tal informação e que nunca observou qualquer trabalho nesse sentido na sede (ZAFALON; SILVA, 2012, p.144).

Mais uma vez ressalta-se a importância da interação da população e a instalação de equipamentos e/ou atividades que permitam o uso público.

\subsubsection{Parque Linear Cajuru}

O Parque Cajuru parte do histórico da recuperação de uma área que sofreu processo de degradação intensa e ainda esta em vias de recuperação. Para tal unidade é propostas as seguintes melhorias:

- O plantio e monitoramento da vegetação ciliar; melhorar a qualidade do uso da terra é de extrema importância, tendo em vista a atual qualidade da água do Rio Atuba; a presença da vegetação também permitirá maior infiltração de águas de chuvas no solo, que em alguns pontos aparenta altos níveis de compactação; além de inibir e dificultar o acesso humano até o leito do rio e suas proximidades, uma vez que esta água encontra-se inviável para contato direto e indireto pelas populações humanas, oferecendo risco à saúde pública;

- Delimitação dos limites do Parque bem como sinalização dos equipamentos e acessos;

- Informações sobre tamanho da área e croqui no portal principal de acesso;

- Demarcações informando à população que ela está em um parque público nos 
diferentes trechos;

- Bebedouros uma vez que o parque oferece inúmeras práticas esportivas e tem uma elevada extensão;

- Sanitários devido ao tamanho da área e a permanência dos usuários no parque.

\subsubsection{Parque Municipal Passaúna}

O Parque Passaúna apresenta as melhores condições entre as funções analisadas; porém existem pontos que podem ser otimizados, tais como:

- Centro de Visitantes: indispensável à área devido à abrangência, representatividade em termos de vegetação da unidade fitogeográfica local e ponto turístico da região; uma área destinada a este fim melhoraria as potencialidades paisagísticas e recreacionais, além de atividades lúdicas e de interpretação da natureza;

- Sinalizações que possibilitem aos usuários se situarem quanto aos diferentes atrativos do parque e em pontos distintos;

- Croqui da área nos principais pontos de acessos;

- Bebedouros em pontos distintos, tal equipamento é de extrema importância devido à extensão da área e o tempo de permanência dos usuários.

As medidas propostas embasaram-se nos dados analisados, porém faz-se necessário a análise pontual de forma cartesiana para averiguar quais são as necessidades da área, sobretudo com a participação da população. 


\section{CONCLUSÕES E CONSIDERAÇÕES FINAIS}

Esta pesquisa teve por objetivo geral demonstrar a incompatibilidade entre as funções de Uso Público e Conservação em parques urbanos. Adotou-se como hipótese que a predominante concepção paisagística e a existência de equipamentos e atividades destinadas ao uso público (lazer e recreação) comprometeriam a conservação dos mesmos.

Tal hipótese foi refutada pelos estudos de casos, em que se mensuraram indicadores relacionados a cada uma destas funções.

No Parque Municipal Nascentes do Belém, verificou-se maior atenção para a manutenção dos aspectos naturais e a insuficiência de elementos com fins de uso público, ocorrendo exatamente o inverso das conjecturas levantadas.

Os estudos conduzidos nos Parques Cajuru e Passaúna, também refutam a hipótese, pois os usos desenvolvem-se de forma equitativa.

A metodologia proposta difere-se das ferramentas existentes ao analisar a área de forma sistêmica, uma vez que, os atributos de conservação e o uso público apresentam a mesma importância.

As áreas selecionadas como estudos de casos, para analisar a eficiência e replicabilidade da técnica corresponderam a universos bem distintos, o que permitiu testa-la em diferentes cenários. O parque Nascentes do Belém, de menor área, representa um espaço destinado à recuperação e conservação de nascentes hídricas; o parque Linear Cajuru, a recuperação de uma área degradada por meio de ocupação irregular e susceptível a inundações; e o Parque Passaúna a conservação de um manancial.

Assim, o sistema de monitoramento, mostrou-se eficiente ao seu propósito, em apontar se o parque cumpre com as funções de conservação e uso público e se ocorre conciliação/equidade, segundo critérios pré-estabelecidos, além de determinar o grau de conciliação; bem como eventuais falhas na gestão e nortear áreas prioritárias ao manejo, uma vez que, quanto menor o escore de um indicador, a administração pública deverá designar maior atenção para estes. Áreas com diferentes processos de formação e concepção paisagística podem refletir resultados distintos.

A ferramenta é quantitativa, pois não verifica a qualidade destes espaços, só indica a existência ou não de determinados elementos relacionados aos usos em questão. Por esta razão, em estudos futuros faz-se necessária a complementação com outras técnicas, como exemplo levantamentos florísticos para determinar a qualidade da vegetação, para identificar 
se a mesma pertence à unidade fitogeográfica em questão e se existe o predomínio de espécies exóticas invasoras; a análise da qualidade de água permitiria também determinar se existe poluição in loco, avaliação da qualidade e distribuição dos equipamentos de uso comum, como pistas de caminhadas, playgrounds, quadras, bancos etc., também poderá, em novos estudos, atribuir classes qualitativas aos usos.

Ressalta-se que uma técnica complementa a outra; a ferramenta serve como ponto de partida para determinar a existência dos elementos mínimos necessários para subsidiar as funções de conservação e uso público; fatores como uso e ocupação da terra podem comprometer a qualidade ambiental da área (ex. cemitério na nascente do Belém), de modo que a influência do entorno deverá ser considerada em estudos de caráter pontual.

Em pesquisas futuras sugere-se elencar como indicador a qualidade de água, visto que tal dado pode ser obtido de forma secundária, por meio de levantamentos do órgão ambiental competente; ainda há que se considerarem, elementos como segurança e iluminação pública, tendo em vista áreas como o Parque Cajuru, que funciona interruptamente; e a distribuição dos equipamentos e infraestruturas destinados aos usuários.

Ressalta-se que, em um sistema piloto desenvolvido, para caracterizar a qualidade da vegetação, incorporou-se aos indicadores de conservação, a identificação de espécies indicadoras de estágio sucessional; tal variável mascarou os resultados, uma vez que, identificou-se espécie de Clímax Florestal (Araucaria angustifolia (Bertol.) Kuntze) em áreas de Estágio Secundário, devido à imunidade de tal espécie ao corte, assegurada por lei.

Futuros estudos, que contemplem o universo de parques de uma cidade como um todo, permitirá análises estatísticas e por conseguinte a generalização do cenário de parques de uma cidade, apontando valores percentuais referentes à presença de vegetação ciliar, equipamentos recreacionais, etc.; podendo inferir a qualidade da gestão de um município frente aos parques, e em quais pontos a administração pública remete maior atenção.

De qualquer modo, o valor desta pesquisa reside no fato de ter possibilitado a sistematização e aplicação in loco de indicadores que podem auxiliar de forma complementar as ferramentas de gestão já existentes. 


\section{REFERÊNCIAS}

AB'SÁBER, A. N. Os domínios de natureza no Brasil: potencialidades paisagísticas. São Paulo: Ateliê Editorial, 2003.

AHERN, J. Greenways as a planning strategy. Landscape and Urban Planning. Vol. 33, p. 131-155, 1995.

ALVAREZ, A. I. Qualidade do espaço verde urbanos: uma proposta de avaliação. 2004. 208f. Tese (Doutorado em Agronomia) - Escola Superior de Agricultura "Luiz de Queiroz". Universidade de São Paulo, Piracicaba, 2004.

ALVES, C. J. S.; RAIMUNDO, S. Percepção ambiental e as práticas do lazer em contato com a natureza no Parque Estadual da Cantareira Núcleo Pedra Grande, São Paulo (SP). OLAM Rio Claro, v. 9, p. 335-360, 2009.

AMORIM, L. M. Ocupação de fundos de vale em áreas urbanas. Estudo de caso: córrego do Minheirinho, São Carlos, SP. 2004. 231f. Dissertação (Mestrado em Engenharia Urbana) - Universidade Federal de São Carlos, São Carlos, 2004.

ANDRADE, R. A. O processo de produção dos parques e bosques públicos de Curitiba. 2001. 141f. Dissertação (Mestrado em Geografia) - Universidade Federal do Paraná, Curitiba, 2001.

ANDRADE, R. V. Complexidade dinâmica: água, expansão urbana e espaços livres públicos - o processo de construção da paisagem do parque Iguaçu, Curitiba-PR. 2009. 207f. Tese (Doutorado em Arquitetura e Urbanismo) - Faculdade de Arquitetura e Urbanismo, Universidade de São Paulo, São Paulo, 2009.

ARAÚJO, C. N. Parques urbanos de Curitiba: 1980-2000. Curitiba: Solar do Rosário, 2007.

ARCHER, P.; GUIMARÃES, A.; MILIKAN, B.; CHAD, E. (Orgs.). Monitoramento e Avaliação de Projetos: métodos e experiências. Brasília: Ministério do Meio Ambiente. Centro de Informação, documentação Ambiental e Editoração, 2004.

BAHLS, A. V. S. O verde na Metrópole: a evolução das praças e jardins de Curitiba (1885-1976). 1998. 230f. Dissertação (Mestrado em História) - Setor de Ciências Humanas, Letras e Artes, Universidade Federal do Paraná, Curitiba, 1998; 
BARBOSA, R. V. R. Áreas verdes e qualidade térmica em ambientes urbanos: estudos em microclimas de Maceió (AL). 2005. 117p. Dissertação (Mestrado em Engenharia Ambiental) - Escola de Engenharia de São Carlo, Universidade de São Paulo, São Carlos, 2005.

BERNATZKY, A. Tree ecology and preservation. Amsterdam: Elsevier Scientific Pub. Co, 1980.

BERTALANFFY, L. Von. Teoria Geral dos Sistemas: fundamentos, desenvolvimento e aplicações. Rio de Janeiro: Editora Vozes, 2010.

BESSERMAN, S. Indicadores: A lacuna das informações ambientais. In: TRIGUEIRO, A. (Coord.). Meio Ambiente no século 21. Rio de Janeiro: Sextante, p. 91-105, 2003.

BINFORD, M.W.; BUCHENAU, M.J. Riparian greenways and water resourses. In: SMITH, D.S.; HELLMUND, P. C. (eds.). Ecology of greenways: desing and function of linear conservation areas. Minneapolis: University of Minnesota Press, 1993.

BIONDI, D. Curso de Arborização Urbana. Curitiba: UNILIVRE, 2000.

BIONDI, D; MULLER, E. Espécies exóticas invasoras no paisagismo dos parques urbanos de Curitiba, PR. Floresta, Curitiba, v. 43, n. 1, p. 69-82, 2013.

BONDUKI, N., FERREIRA, J. S. W. (Coord.). Pesquisa e Análise de Aplicação de Instrumentos em Planejamento Urbano Ambiental no Município de São Paulo. Relatório II - Sistematização bibliográfica sobre planejamento urbano-ambiental e zoneamento ambiental. São Paulo: LabHab FAUUSP, 2006.

BORGES, J L. O impacto da ocupação de fundos de vale em áreas urbanas. Caso: Córrego do Gregório - São Carlos (SP). 2006. 119p. Dissertação (Mestrado em Engenharia Urbana) - Universidade de São Carlos, São Carlos, 2006.

BOTELHO, R. G. M.; SILVA, A. S. Bacias Hidrográficas e qualidade ambiental. In: VITTE, A. C.; GUERRA, A. J. T. (orgs). Reflexões sobre a Geografia Física no Brasil. Rio de Janeiro: Bertrand Brasil, 2004.

BOTELHO, S. A.; DAVIDE, A. C. Métodos silviculturais para recuperação de nascentes e recomposição de matas ciliares. In: SIMPÓSIO NACIONAL DE RECUPERAÇÃO DE ÁREAS DEGRADADAS, 5., 2002, Belo Horizonte. Anais... Belo Horizonte: UFLA, 2002. p. 123-145. 
BRACHT, C. de C. Os instrumentos jurídicos e programas de gestão dos recursos hídricos e seus reflexos na qualidade das águas na bacia hidrográfica do rio Belém. 2008. 232f. Dissertação (Mestrado em Gestão Urbana) - Programa de Pós-Graduação em Gestão Urbana, Pontifícia Universidade Católica do Paraná, Curitiba, 2008.

BRAGA, B. et al. Introdução a Engenharia Ambiental. São Paulo: Pearson Prentice Hall, 2005.

BRANDALIZE, M. C. B.; BOLLMANN, H. A. Mapeamento da percepção ambiental dos moradores da bacia hidrográfica do rio Belém utilizando o SPRING. In: SIMPÓSIO BRASILEIRO DE SENSORIAMENTO REMOTO, 14., 2009, Natal. Anais... Natal: INPE, 2009. p. 3613-3619.

BRASIL. Lei $\mathrm{n}^{\circ} 9.985$ de 18 de Julho de 2000. Institui o Sistema Nacional de Unidades de Conservação - SNUC. Diário Oficial da União, Brasília, DF, 19 jul. 2000.

BRASIL. Lei $\mathrm{n}^{\circ} 12.651$ de 25 de Dezembro. Dispõe sobre a proteção da vegetação nativa. Diário Oficial da União, Brasília, DF, 26 dez. 2012.

BRASILIO, W. Industrialização e degradação ambiental: o caso do rio Belém, em Curitiba, PR. 2005. 95f. Dissertação (Mestrado em Geografia) - Programa de Pós-graduação em Geografia, Universidade Federal do Paraná, Curitiba, 2005.

BROSE, M. Aprendizado prático com monitoramento e avaliação - estimulo a reflexão. In: ARCHER, P.; GUIMARÃES, A.; MILIKAN, B.; CHAD, É (Orgs.). Monitoramento e Avaliação de Projetos: métodos e experiências. Brasília: Ministério do Meio Ambiente, Centro de Informação, documentação Ambiental e Editoração, p. 12-33, 2004.

BROWN JÚNIOR, K. Insetos como rápidos e sensíveis indicadores de uso sustentável de recursos naturais. In: MARTOS, H. L.; MAIA, N. B. (Coords.). Indicadores Ambientais. Sorocaba: p. 143-156, 1997.

BUCCHERI FILHO, A. T. O planejamento dos parques no município de Curitiba, PR: planejamento sistemático ou planejamento baseado em um modelo oportunista?. Revista Caminhos de Geografia, Curitiba, v.13, n. 41, p. 206-222, 2012.

BUSCH, O. M. S. Qualidade da água e saúde humana: riscos potenciais face ao processo de ocupação urbana no entorno da represa do Passaúna - Curitiba - PR. 2009. 277f. Tese (Doutorado em Meio Ambiente e Desenvolvimento) - Programa de Doutorado em Meio Ambiente e Desenvolvimento, Universidade Federal do Paraná, Curitiba, 2009. 
CANIL, K. Indicadores para o monitoramento de processos morfodinâmicos: aplicação na bacia do Ribeirão de Pirajussara (SP). 2006. 168f. Tese (Doutorado em Geografia Física) - Faculdade de Filosofia Letras e Ciências Humanas, Universidade de São Paulo, São Paulo, 2006.

CASTELNOU NETO, A. M. N. Ecotopias Urbanas: imagem e consumo dos parques curitibanos. 2005. 470f. Tese (Doutorado em Meio Ambiente e Desenvolvimento), Universidade Federal do Paraná, Curitiba, 2005.

CAVALHEIRO, F. Arborização urbana: planejamento, implantação e condução. In CONGRESSO BRASILEIRO DE ARBORIZAÇÃO URBANA, 2., São Luiz, 1994, Anais... São Luiz: SBAU, 1994. p. 227-231.

CAVALHEIRO, F. Urbanização e alterações ambientais. In: TAUK, M. S. (org.). Análise ambiental: uma visão multidisciplinar. São Paulo: UNESP, 1995. p. 114-124.

CAVALHEIRO, F.; GUZZO, P.; ROCHA, Y. T.; NUCCI, J. C. Proposição de terminologia para o verde urbano. Boletim Informativo da Sociedade Brasileira de Arborização Urbana. Rio de Janeiro, v. 7, n.3, p. 7-7, 1999.

CHRISTOFOLETTI, A. Geomorfologia. São Paulo: Edusp, 1974.

CHRISTOFOLETTI, A. Geomorfologia Fluvial. São Paulo: Edgard Blücher, 1980.

CONAMA. Resolução no 357 de 17 de Março de 2005. Dispõe sobre a classificação dos corpos de água e diretrizes ambientais para o seu enquadramento, bem como estabelece as condições e padrões de lançamento de efluentes, e dá outras providências. Diário Oficial da União, Brasília, DF, 18 mar. 2005.

CORADINI, M. P. Leituras de Paisagens em Parques Urbanos: função e percepção. 2008. Dissertação (Mestrado em Geografia, Meio Ambiente e Desenvolvimento) - Centro de Ciências Exatas, Universidade Estadual de Londrina, Londrina, 2008.

COSTA, D. O. Parâmetros Normativos para a Gestão de Parques Urbanos do Distrito Federal. 2011. 138f. Dissertação (Mestrado em Geografia) - Programa de Pós Graduação em Geografia, Universidade de Brasília, Brasília, 2011.

CRANZ, G. Changin roles of urban parks - From pleasure garden to open space. Landcape, n.2, 1978. Disponível em:

<http://www.spur.org/publications/library/article/changingrolesurbanparks06012000> Acesso 
em: jan. 2013.

CUNHA, S. B.; GUERRA, A. J. T. Degradação Ambiental. In: Geomorfologia e Meio Ambiente. GUERRA, A. J. T; CUNHA, S. B. Rio de Janeiro: Bertrand Brasil, 2000.

CUNHA, S. B.; COELHOM. C. Política e Gestão Ambiental. In: CUNHA, S. B.; GUERRA, A. J. T. (orgs.). A questão ambiental: diferentes abordagens. Rio de Janeiro: Bertrand Brasil, p. 43-79, 2010.

CURITIBA. Lei n. 9.804, de 03 de janeiro de 2000. Cria o sistema de unidades de conservação do município de Curitiba e estabelece critérios e procedimentos para implantação de novas unidades de conservação. Diário Oficial, Curitiba, PR 04 jan. 2000.

CURITIBA. Secretaria Municipal do Meio Ambiente - Parques e bosques. Disponível em: <http://www.curitiba.pr.gov.br/conteudo/parques-e-bosques-smma-secretaria-municipaldo-meio-ambiente/267> Acesso em: dez. 2012.

CURITIBA. Secretária Municipal do Meio Ambiente - Recursos Hídricos. Disponível em: 〈http://www.curitiba.pr.gov.br/multimidia/00085317.pdf〉. Acesso em: jan/2014.

DELPOUX, M. Ecossistema e Paisagem. Revista IG-USP, Série Métodos em Questão, São Paulo, n. 7, 1974.

DERISIO, J. C. Introdução ao controle da Poluição Ambiental. São Paulo: Oficina de Textos, 2012.

DONNELLY, A.; JONES, M.; O'Mahony, T.; BYRNE, G. Selecting environmental indicator for use in strategic environmental assessment, Environmental Impact. Assessment Review, v. 27, n. 2, p. 161-175, 2007.

DREW, D. Processos interativos homem-meio ambiente. Rio de Janeiro: Bertrand Brasil, 8 ed. 2011.

FERRARI, E. A. Monitoramento de Impactos Econômicos de Práticas Agroecológicas. In: ARCHER, P.; GUIMARÃES, A.; MILIKAN, B.; CHAD, É. (Orgs.). Monitoramento e Avaliação de Projetos: métodos e experiências. Brasília: Ministério do Meio Ambiente. Centro de Informação, documentação Ambiental e Editoração, v. 1, p. 87-119, 2004.

FIGUEIRÓ, A. S. Da "natureza que nos cerca" a natureza cercada: uma introdução ao debate 
da conservação de florestas em áreas urbanas. OLAM - Ciência e Tecnologia, Rio Claro, v. 11, p. 171, 2011.

FORATTINI, O. P. Novos aspectos da saúde pública. Revista de Saúde Pública, São Paulo, v. 25, p. 75-86, 1991.

FRANCO, M. A. R. Desenho Ambiental: uma introdução à arquitetura da paisagem com o paradigma ecológico. São Paulo: Annablume/Fapesp, 2008.

FRIEDERICH, D. O Parque Linear como instrumento de planejamento e gestão das áreas de fundo de vale urbanas. 2007. 272f. Dissertação (Mestrado em Planejamento Urbano e Regional) - Universidade Federal do Rio Grande do Sul, Porto Alegre, 2007.

GALANTE, M. L. V.; BESERRA, M. M. L.; MENEZES, E. O. Roteiro metodológico de planejamento: parque nacional, reserva biológica, estação ecológica. Brasilía, DF: IBAMA, 2002, 135p. Disponível em: <http://www.icmbio.gov.br/portal/images/stories/imgsunidades-coservacao/roteiroparna.pdf: Acesso em: 24/fev/2013.

GARCIA, F. E. S. Cidade espetáculo: política, planejamento e city marketing. Curitiba: Palavra, 1996.

GEISSLER, H. J.; CLOCH, R. E. N. Análise histórica das enchentes em Curitiba-PR: medidas propostas e consequências observadas. In: SIMPÓSIO BRASILEIRO DE DESASTRES NATURAIS, 1., 2004. Florianópolis, Anais... Florianópolis, GEDN/UFSC, 2004. p. 507-523.

GOBBI, E. F.; OSTRENSKY NETO, A. (orgs.). Projeto Águas do Amanhã: um olhar crítico sobre a Bacia Hidrográfica do Alto Iguaçu. Curitiba: Grupo Rede Paranaense de Comunicação - GRPCom, 2011. Disponível em:

<http://www.gazetadopovo.com.br/aguas/Relatorio-Aguas.pdf> Acesso em: jan/2014.

GOEDEN, R.D. Critique and revision of Harris' scoring system for selection of insect agents in biological control of weeds. Protection Ecology, v. 5, p. 287-301, 1983.

GONÇALVES, F. L. T.; KRIEGER, S. Estudos biometeorológicos do clima urbano. São Paulo: USP Instituto de Astronomia, Geofísica e Ciências Atmosféricas, 2004.

GONZAGA, C. A. M.; WANDEMBRUCK, A.; SEGER, C. D.; BIONDI, D. Análise paisagística da trilha recreativa do Parque Municipal do Passaúna, Curitiba, Paraná. Cad. Biodiversidade, v. 4, n. 2, p. 66-73, 2004. 
GOOGLE EARTH. Software para download. Disponível em:

<https://www.google.com/earth/>. Acesso em: jan. 2014.

GREY, G. W.; DENEKE, F. J. Urban Forestry. New York: John Wiley, 1978.

HARRIS, P. The selection of effective agents for the biological control of weeds. The Canadian Entomologist, v. 105, p. 1945-1503, 1973.

HEINK, U. KOWARIK, I. What are indicators? On the definition of indicators in ecology and environmental planning. Ecological Indicators, v. 10, Issue 3, p.584-593, 2010.

HENGEVELD, H.; VOCHT, C. de. Role of water. Urban Ecology, v. 6, 1982.

HEPCAN, S. A. A Methodological Approach for Designating Management Zones in Mount Spil National Park, Turkey. Environmental Management, v. 26, n. 3, p. 329-338, 2000.

HILDEBRAND, E.; GRAÇA, L. R.; HOEFLICH, V.; A. "Valoração Contingente" na avaliação econômica de áreas verdes urbanas. Revista Floresta, Curitiba, n. 32, p. 121-132, 2002.

HOLMES, R. M. Indicadores de risco ecológico na gestão dos parques urbanos do Distrito Federal. 2008. 62f. Dissertação (Mestrado em Planejamento e Gestão Ambiental) Pontifícia Universidade Católica de Brasília, Brasília, 2008.

HOWARD, E. Cidades-Jardins de Amanhã. São Paulo: Hucitec, 1996.

IAP (Instituto Ambiental do Paraná). Monitoramento Da qualidade das águas dos rios da Bacia do Alto Iguaçu, na região metropolitana de Curitiba, no período de 2005 a 2009. IAP: Curitiba, 2009.

IAPAR (Instituto Agronômico do Paraná). Classificação climática. Disponível em: <http://www.iapar.br/modules/conteudo/conteudo.php?conteudo=597> Acesso em jul. 2012.

IBGE (Instituto Brasileiro de Geografia e Estatística). Censo demográfico. Disponível em: http://www.ibge.gov.br/cidadesat/topwindow.htm?1. Acesso em: dez. 2011.

IPPUC (Instituto de Pesquisa e Planejamento Urbano de Curitiba). História do planejamento. Disponível em: <http://www.ippuc.org.br/ippucweb/sasi/home/>. Acesso em: dez. 2011. 
IPPUC (Instituto de Pesquisa e Planejamento Urbano de Curitiba). Levantamento das unidades de conservação. Curitiba: IPPUC, 2012. Disponível: $<$ http://ippucweb.ippuc.org.br/Bancodedados/Curitibaemdados/anexos/Hist\%C3\%B3rico\%20 dos\%20Parques\%20e\%20Bosques.pdf> Acesso em: dez 2012.

IPPUC (Instituto de Pesquisa e Planejamento Urbano de Curitiba). Mapas. Disponível em: <http://www.ippuc.org.br/default.php> Acesso em: nov. 2013.

IPPUC (Instituto de Pesquisa e Planejamento Urbano de Curitiba). Áreas inundáveis. 2001. Disponível em: <http://www.ippuc.org.br/default.php> Acesso em: nov. 2011.

IUCN (International Union for Conservation of Nature). Guidelines protected Area Management Categories. Gland: UICN, 1994. Disponível em: http://www.unepwcmc.org/protected_areas/categories/eng/c2.pdf. Acesso em: nov. 2010.

KLIASS, R. G. Parques Urbanos de São Paulo e sua evolução na cidade. São Paulo: Pini, 1993.

KLIASS, R. G.; MAGNOLI, M.M. Áreas verdes de recreação. Paisagem Ambiente: ensaios, São Paulo, n. 21, p. 245-256, 2006.

LIMA, A. M. L.; CAVALHEIRO, F.; NUCCI, J. C.; SOUSA, M. A. L. B. FIALHO, N. O. DEL PICCHIA, P. C. D. Problemas de utilização na conceituação de termos como espaços livres, áreas verdes e correlatos. In: CONGRESSO BRASILEIRO DE ARBORIZAÇÃ̃O URBANA, 2. Anais... São Luís: 1994.

LIRA, J.A. Paisagismo - Princípios Básicos. Viçosa: Aprenda Fácil, 2001.

LYNCH, K. A imagem da cidade. São Paulo: Martins Fontes, 1995.195p.

LOWRENCE, R.; ALTIER, L. E.; NEWBOLD, J. D., SCHNABEL, R. R.; GROFFMAN, P. M.; DENVER, J. M.; CORREL, D. L.; GILLIAM, J. W.; ROBINSON, J. L.; BRINSFIEL, R. B.; STAVER, K. W.; LUCAS, W. TODD, A. H. Water quality functions of riparian forest buffers in chesapeak bat watersheds. Environmental Management, New York, v. 21(5), p.687-712, 1997.

MAACK, R. Geografia Física do Estado do Paraná. Curitiba: Clichês, 1968.

MACEDO, R. K. A importância da Avaliação Ambiental. In: TAUK, M. S. (org.). Análise 
ambiental: uma visão multidisciplinar. São Paulo: UNESP, p. 13-32, 1995.

MACEDO, S. S.; SAKATA, F. G. Parques urbanos no Brasil. São Paulo: Imprensa Oficial do Estado de São Paulo, 2003.

MACHADO, E. S.; POLATTI, O. R. de R.; SOUZA, J.; DORNELES de; SAMEK, J. L. HEISLER JÚNIOR, I. B.; SUCHECKI, I. (Coords.). Plano das bacias do alto Iguaçu e afluentes do alto ribeira. Curitiba: Instituto das Águas do Paraná, 2013. Disponível em: <http://www.aguasparana.pr.gov.br/arquivos/File/COALIAR/Publicacoes/plano_de_bacias/fi nalizacao_plano.pdf> Acesso em: jan. 2014.

MAGALHÃES JÚNIOR, A. P. Indicadores ambientais e recursos hídricos: realidade e perspectiva para o Brasil a partir da experiência francesa. Rio de Janeiro: Bertrand Brasil, 2007.

MAGALHÃES, R. A. Erosão: definições, tipos e formas de controle. In: SIMPÓSIO NACIONAL DE CONTROLE DE EROSÃO, 7., Goiânia. Anais... Goiânia: UFG, 2001, p. 111.

MAGnOli, M. M. O parque no desenho urbano. Paisagem Ambiente: ensaios, São Paulo, n. 21, p. 199-214, 2006.

MANTOVANI, W. A diversidade biológica em parques urbanos. In: GLEZER, R.; MANTOVANI, M. S. M (org.). Parques urbanos e meio ambiente: desafios e usos. São Paulo: Parque Cientec/USP, p. 125-162, 2005.

MARCONI, M. A.; LAKATOS, E. M. Fundamentos de metodologia científica. São Paulo: Atlas, 2003.

MARSH, W. M. Landscape Planning - Environmental Applications. New York: John Willey, 2005.

MARTINS JÚNIOR, O. P. Arborização Urbana \& Qualidade de Vida: Classificação dos Espaços Livres e Áreas Verdes. Goiânia: Kelps/UCG, 2007.

MARTOS, H. L.; MAIA, N. B. Indicadores Ambientais. Sorocaba: Liber Arte, 1997.

MATOS, F.; LOPES, J. C.; VITORINO, M. A. Parque Urbano e estratégias de bem-estar nas cidades médias em Portugal Continental. O caso de Penafiel. In: COLÓQUIO IBÉRICO DE GEOGRAFIA, 10. 2005, Évora. Anais... Évora: Universidade de Évora, 2005. 
MASCARÓ, L. R. MASCARÓ, J. L. Vegetação Urbana. Porto Alegre: UFRGS, 2002.

MAZZEI, K.; COLESANTI, M. T. M.; SANTOS, D. G. Áreas verdes urbanas, espaços livres para o lazer. Sociedade e Natureza, n. 19, p. 33-43, 2007.

McHARG, I. L. Design with nature. Garden City, NY: Doubleday, 1971.

MEDEIROS, R.; IRVING, M.; GARAY, I. A Proteção da Natureza no Brasil: evolução e conflitos de um modelo em construção. RDE - Revista de Desenvolvimento Econômico, n. 9, p. 83-93, 2004.

MENEZES, C. L. Desenvolvimento urbano e meio ambiente: a experiência de Curitiba. Campinas: Papirus, 1996.

MIELKE, E. C. Árvores exóticas invasoras em Unidades de Conservação de Curitiba, Paraná: subsídios ao manejo e controle. 2012, 115f. Tese (Doutorado em Agronomia).Departamento de Fitotecnia e Fitossanitarismo, Universidade Federal do Paraná, Curitiba, 2012.

MINISTÉRIO DA SAÚDE. Portaria n 2.914 de 12 de Dezembro de 2011. Dispõe sobre os procedimentos de controle e de vigilância da qualidade da água para consumo humano e seu padrão de potabilidade. Diário Oficial da União, Brasília, DF, 13 dez. 2011.

MITCHELL, G.; MAY, A., McDONALD, A. PICABUE: a methodological framework for the development of indicators of sustainable development. International Journal of Sustainable Development and World Ecology, v. 2, n. 2., p. 104-123, 1995.

MOURA, C.; DRABOWSKI, B. B.; SILVA, S. A. D. P.; ANDRADE, M. S.; ANDRADE, M. A. Avaliação da aplicabilidade da metodologia de DRP para parques naturais municipais: uma experiência no Parque Fazenda Lagoa do Nado. Sinapse Múltipla, Betim, v. 1, p. 31-43, 2012.

MONTEIRO, C.A.F. Geossistemas: a história de uma procura. São Paulo: Contexto, 2000.

MÜLLER, C. R. C.; OLIVEIRA, K. L. de; MOTTA, J. T. W. (orgs.). Plano municipal de recuperação e conservação da Mata Atlântica: Curitiba-PR. Curitiba: SMMA, 2012.

NASCIMENTO, R. P do. Conservação de invertebrados em áreas urbanas: um estudo de caso com formigas no Cerrado brasileiro. 2005. 71f. Dissertação (Mestrado em Ecologia e Conservação dos Recursos Naturais) - Universidade Federal de Uberlândia, Uberlândia, 2005. 
NUNES, F. G.; RIBEIRO, N. C. FIORI, A. P. Propriedades morfométricas e aspectos físicos da bacia hidrográfica do rio Atuba: Curitiba-Paraná. In: SIMPÓSIO NACIONAL DE GEOMORFOLOGIA- GEOMORFOLOGIA TROPICAL E SUBTROPICAL: PROCESSOS, MÉTODOS E TÉCNICAS, 6. 2006, Goiânia. Anais... Goiânia: UFG, 2006, p. 1-10.

NUNES JÚNIOR, P. C. O Parque do Ibirapuera e o lazer na cidade de São Paulo: da descrição à apropriação. Revista Rua, Campinas, n. 17, v. 2, p. 145-160, 2011.

OLIVEIRA, D. Planejamento urbano e processo decisório: o caso de Curitiba. Boletim do Departamento de História da UFPR, Curitiba, n. 31, p. 53 62, 1994.

OLIVEIRA, E. L. de A.; RECKZIEGEL, B. W. ROBAINA, L. E. de S. Modificações na morfologia dos canais de drenagem da bacia hidrográfica do arroio cadena, Santa Maria/RS. Rev. RA'E GA, Curitiba, n. 11, p. 103-113, 2006.

OLIVEIRA, M. Perfil Ambiental de uma Metrópole Brasileira: Curitiba, seus parques e bosques. Revista Paranaense de desenvolvimento, Curitiba, n.88, p. 37-54, 1996.

OLIVEIRA, P. T. S. B. Sistema de Indicadores Ambientais: um modelo para o monitoramento de parques urbanos. 2007. Dissertação (Mestrado em Tecnologia Ambiental) - Instituto de Pesquisas Tecnológicas do Estado de São Paulo, São Paulo, 2007.

OLIVEIRA, P. T. S. B.; BITAR, O. Y. Indicadores ambientais para o monitoramento de parques urbanos. InterfacEHS, v. 4, p. 1-14, 2009.

OLIVEIRA, R. B. Análise Morfológica, dinâmica ambiental e uso do solo em bacias hidrográficas periurbanas (Maringá-PR). In: SIMPÓSIO SOBRE PEQUENAS CIDADES E DESENVOLVIMENTO LOCAL, 1.; SEMANA DE GEOGRAFIA, 17., 2008, Maringá. Anais... Maringá: UEM, 2008, p. 01-10.

PADILHA, D. C. C. Estudo de Áreas de Preservação Permanente (APP's) de corpos d'água em zonas urbanas como subsídio à legislação pertinente. 2009, 135f. Dissertação (Mestrado em Engenharia Urbana) - Universidade Federal de São Carlos, São Carlos, 2009.

PAREIRA, V. de P. Erosão hídrica e indicadores ambientais. In: Indicadores Ambientais. MARTOS, H. L.; MAIA, N. B. (Coords.). Sorocaba: 1997.

PEREIRA, F. C.; SILVA, R. R. de S.; VEIGA, A. C. P. Análise do nível de hemerobia no bairro Centro Cívico em Curitiba - Paraná. Revista Percurso - NEMO, Maringá, v.3, n.1, p.125-145, 2011. 
PHILIPPI JÚNIOR, A.; RODRIGUES, J. E. R. A Gestão de parques urbanos na cidade de São Paulo. In: GLEZER, R. e M.; MARTA S. M. (orgs.). Parques urbanos e meio ambiente: desafios e usos. São Paulo: Parque Cientec/USP, p. 125-162, 2005.

PIMENTEL, G. B. R. Avaliação ergonômica da sinalização em três parques estaduais em Minas Gerais. 2007, 79f. Dissertação (Mestrado em Ciência Florestal) - Universidade Federal de Viçosa, Viçosa, 2007.

PINHO, P. M. Aspectos ambientais da implantação de "vias marginais" em áreas urbanas de fundo de vale. 1999. Dissertação (Mestrado em Engenharia Urbana) Universidade Federal de São Carlos, São Carlos, 1999.

POPPER, K. S. A lógica da pesquisa científica. São Paulo: Cultrix, 1975.

POSADA, M. I.; ARROYAVE, M. del P.; FERNANDEZ, C. Influencia de la vegetación en los niveles de ruído urbano. Rev. EIA.Esc.Ing.Antioq, n.12, p. 79-89, 2009.

REGO, R. L. As Cidades Plantadas: os britânicos e a construção da paisagem do norte do Paraná. Londrina: Humanidades, 2009.

REIS, R. S. Determinantes ambientais para a realização de atividades físicas nos parques urbanos de Curitiba: uma abordagem sócio-ecológica da percepção dos usuários. 2001, 113f. Dissertação (Mestrado em Educação Física) - Centro de Desportos da Universidade Federal de Santa Catarina, Santa Catarina, 2001.

RIBEIRO, C. M.; BEZ-BATTI, E. C.; YAMANE, A. T.; FILA, A. E., BRUZAMOLIN, R. H. PASTORIO, S. C.; CHIAMOLERA, L.; FREITAS-LIDANI, K. C. Análise microbiológica do Rio Belém, Curitiba-PR. Cadernos da Escola de Saúde. n.2, p. 1-11, 2009.

ROCHA, Y. T. Vegetação urbana: caracterização e planejamento. In: TÂNGARI, V. R.; SCHLEE, M. B.; ANDRADE, R.; DIAS, M. A. (orgs.). Águas Urbanas: uma contribuição para a regeneração ambiental como campo disciplinar integrado. Rio de Janeiro: FAU/UFRJ, p. 113-122, 2007.

RODERJAN, C. V.; GALVÃO, F.; KUNIYOSHI, Y. S.; HATSCHBACH, G.G. As unidades fitogeográficas do Estado do Paraná. Ciência \& Ambiente, Santa Maria, v. 24, p. 75-92, 2002.

RODRIGUEZ, J. M. M.; SILVA, E. V. da; CAVALCANTI, A. P. B. Geoecologia das Paisagens: uma visão geossistêmica da análise ambiental. Fortaleza: Edições UFC, 2007. 
ROSS, J. L. S. Análise Empírica da Fragilidade dos Ambientes Naturais e Antropizados. Revista do Departamento de Geografia, São Paulo, n. 8, p.63-74, 1994.

SÁNCHEZ, L. E. Avaliação de impacto ambiental: conceitos e métodos. São Paulo: Oficina de Textos, 2013.

SANTOS, N. R. Z. dos. Avaliação da função sócio-ambiental da Floresta Nacional de Canela (RS) como subsídio ao turismo e educação ambiental. 2005. 243f. Tese (Doutorado em Engenharia Florestal) - Universidade Federal de Santa Maria, 2005.

SANTOS, R. F. Planejamento Ambiental: teoria e prática. São Paulo: Oficina de Textos, 2004.

SAUNITI1, R. M.; FERNANDES, L. A.; BITTENCOURT, A. V. L. Estudo do assoreamento do reservatório da barragem do rio Passaúna - Curitiba-PR. Boletim Paranaense de Geociências, n. 54, p. 65-82, 2004.

SHIBAO, K. (coord.). Atenuação da poluição sonora por meio de vegetação florestal. Brasília: ANAC, 1984. Disponível em:

<http://www2.anac.gov.br/portal/media/IAC4104.pdf> Acesso em: jan. 2014.

SHIELDS, D. J.; SOLAR, S. V.; MARTIN, W. E. The role of values and objectives in communicating indicators of sustainability. Ecological Indicators, v. 2, p. 149-160, 2002.

SOLECKI, W. D.; WELCH J. M. Urban parks: green spaces or green walls?. Landscape and Urban Planning, vol. 32, p. 93-106, 1995.

SORENSEN, M.; BARZETTI, V; KEIPI, K.; WILLIAMS, J. Manejo de las áreas verdes urbanas: documento de buenas prácticas. Washington: ENV, 1998.

SMITH, D. S.; HELLMUND, P. C. Ecology of Greenways: desing and function of linear conservation areas. Minessota: University of Minnesota Press, 1993.

SILVA, A. G. A experiência da ActionAid Brasil - Construção participativa de um sistema de planejamento, monitoramento e avaliação participativa. In: ARCHER, P.; GUIMARÃES, A.; MILIKAN, B.; CHAD, É. (Orgs.). Monitoramento e Avaliação de Projetos: métodos e experiências. Brasília: Ministério do Meio Ambiente, p. 34-61, 2004.

SILVA, L. J. M. Parques urbanos: a natureza na cidade - uma análise da percepção dos 
atores urbanos. 2003, 113f. Dissertação (Mestrado em Desenvolvimento Sustentável) Centro de Desenvolvimento Sustentável, Universidade de Brasília, Brasília, 2003.

SOUZA, W. de. Caracterização da cobertura arbórea dos parques urbanos da Cidade de Recife - PE. 2011, 101f. Tese (Doutorado em Ciências Florestais) - Departamento de Ciências Florestais, Universidade Federal Rural de Pernambuco, Pernambuco, 2011.

SPVS (SOCIEDADE DE PESQUISA EM VIDA SELVAGEM E EDUCAÇÃO AMBIENTAL). Apoio à Conservação da Biodiversidade no Município de Curitiba. Programa de avaliação e quantificação do potencial de absorção de carbono por florestas nativas em Curitiba. Relatório Final de Atividades (abril/maio 2009). Curitiba: SPVS - relatório não publicado, 2009.

TAVARES, L. P. de O. São José dos Pinhais no contexto da recente industrialização metropolitana: reflexos socioespaciais. Revista Paranaense de Desenvolvimento, Curitiba, v. 108, p. 33-59, 2005.

TEIXEIRA, R. S. Análise da Apropriação pelos usuários de parques urbanos: estudo de casos na bacia da Pampulha - Belo Horizonte, MG. 2007. 127f. .Dissertação (Mestrado em Ciência Florestal). Universidade Federal de Viçosa, Viçosa, 2007.

THOMAS, L.; MIDDLETON, J.; PHILLIPS, A. (eds.). Guidelines for Management Planning of Protected Areas. World Commission on Protected Areas (WCPA) - Best Practice Protected Area Guidelines Series, Switzerland and Cambridge, UK: IUCN, 2009.

TRENTIN, G.SIMON, A.L.H. Análise da ocupação espacial urbana nos fundos de vale do Município de Americana SP, BRASIL. In: ENCONTRO DE GEÓGRAFOS DE AMÉRICA LATINA, 12., 2009, Montivideo. Anais... Montevideo: 2009.

VAITSMAN, J.; RODRIGUES, W. S. R.; PAES-SOUSA, R. O Sistema de Avaliação e Monitoramento das Políticas e Programas Sociais: a experiência do Ministério do Desenvolvimento Social e Combate à Fome do Brasil. Brasília: UNESCO, 2006.

XAVIER, C., da F. Avaliação da influência do uso e ocupação do solo e de características geomorfológicas sobre a qualidade das águas de dois reservatórios da região metropolitana de Curitiba-PR. 2005. 169f. Dissertação (Mestrado em Ciências do Solo) Universidade Federal do Paraná, Curitiba, 2005.

YIN, R. K. Estudo de caso: planejamento e métodos. Porto Alegre: Bookman, 2010. 
ZAFALON, R.; SILVA, S.K. A criação de Unidades de Conservação como instrumento de proteção aos recursos hídricos: estudo de caso do Parque Nascentes do Belém - Curitiba-PR. Revista Geografar, Curitiba, v.7, n.2, p.126-152, 2012.

ZANELLA, M. A. Inundações Urbanas em Curitiba/PR: impactos, riscos e vulnerabilidade socioambiental no Bairro Cajuru. 2006. Tese (Doutorado. Meio Ambiente e Desenvolvimento) - Universidade Federal do Paraná, 2006.

ZANELLA, M. E. Impactos pluviais no bairro Cajuru - Curitiba-PR. Mercator, n.11, p. 93$105,2007$.

ZIRKL, F. Desenvolvimento Urbano de Curitiba (Brasil): cidade modelo ou uma exceção? Actas latinoamericanas de Varsovia, Polônia, n.26, p. 87-98, 2003.

WHATElY, M.; SANTORO, P. F.; GONÇALVES, B. C.; GONZATTO, A. M. (orgs.). Parques urbanos municipais de São Paulo: subsídios para a gestão. São Paulo: Instituto Socioambiental, 2008. 
ANEXOS 
ANEXO A - Bacias Hidrográficas de Curitiba, Paraná

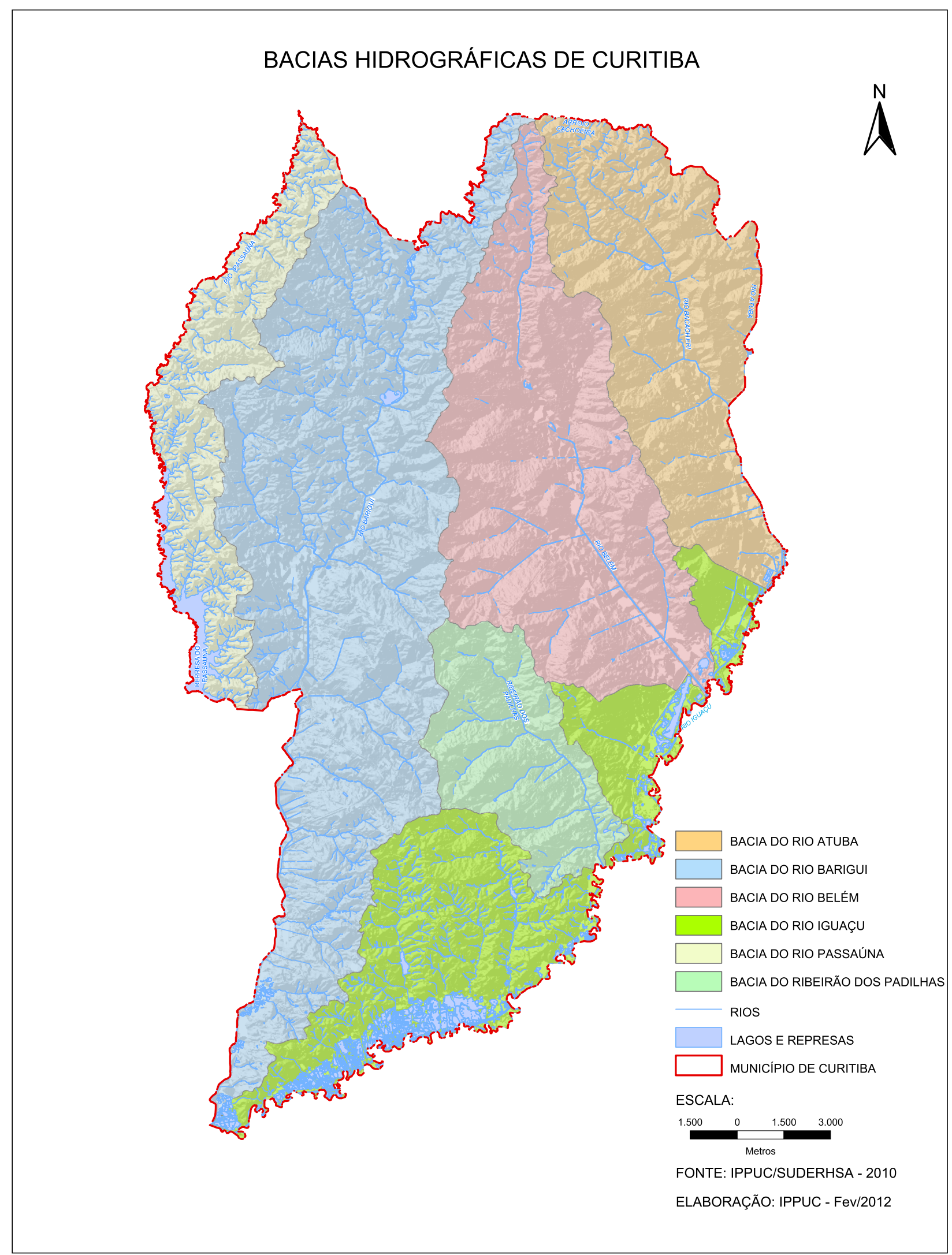

Fonte: Adaptado de IPPUC, 2013. 
ANEXO B - Sistema hidrográfico de Curitiba-PR e áreas sujeitas a inundações

\section{ÁREAS INUNDÁVEIS MUNICÍPIO DE CURITIBA}

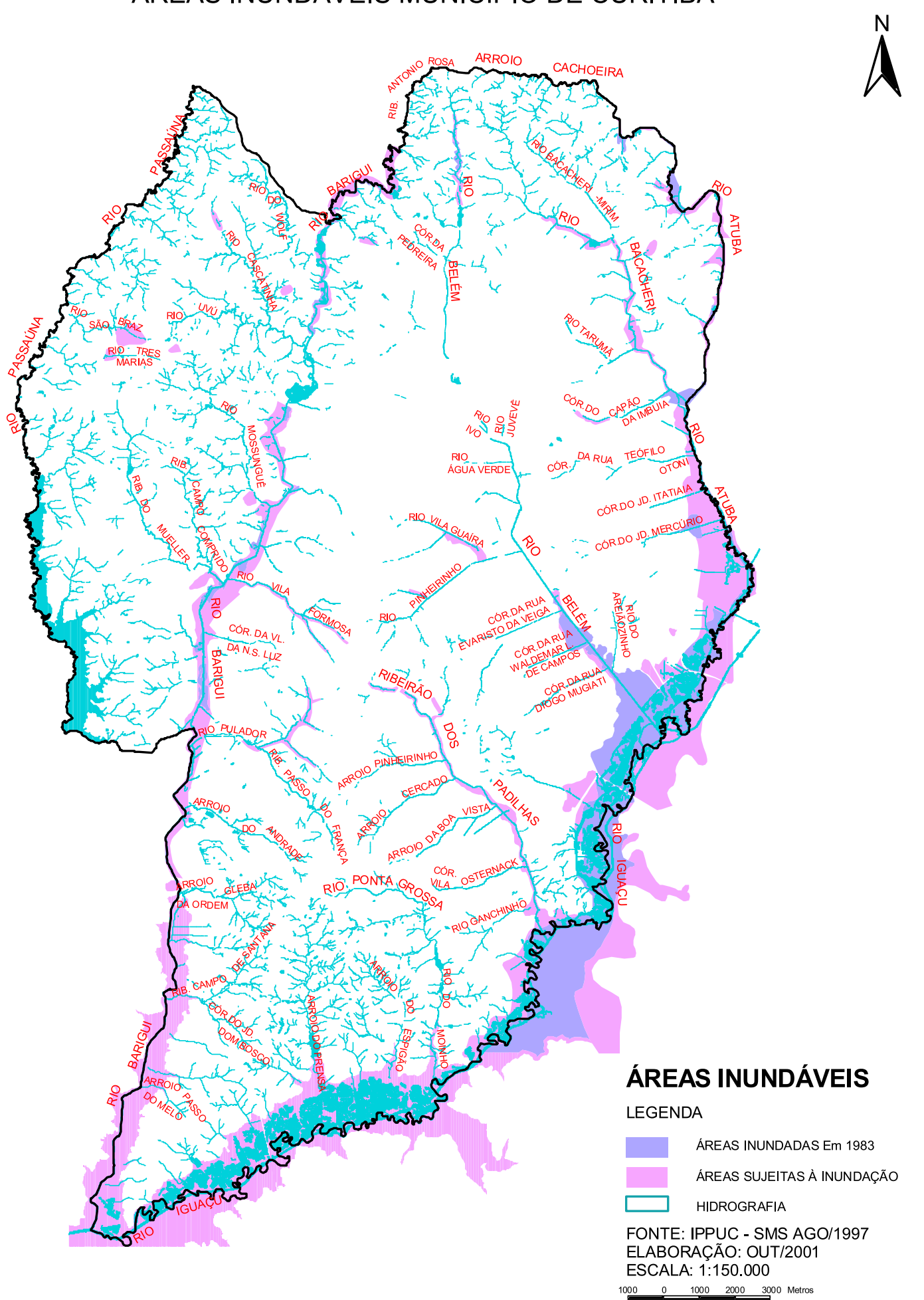

Fonte: IPPUC, 2011 
ANEXO C - Lei Municipal no 9.804/2000

\author{
LEI N ${ }^{\circ} 9.804$
}

de 03 de janeiro de 2000.

"Cria o Sistema de Unidades de Conservação do Município de Curitiba e estabelece critérios e procedimentos para implantação de novas Unidades de

Conservação."

\title{
A CÂMARA MUNICIPAL DE CURITIBA, CAPITAL DO ESTADO DO PARANÁ, aprovou e eu, Prefeito Municipal, sanciono a seguinte lei:
}

Art. $1^{\circ}$. Para efeitos desta lei, entende-se por Sistema de Unidades de Conservação o conjunto de Unidades de Conservação instituídas pelo Poder Público e classificadas de acordo com esta lei.

Art. $2^{\circ}$. Para efeitos desta lei, entende-se por Unidades de Conservação áreas no Município de propriedade pública ou privada, com características naturais de relevante valor ambiental ou destinadas ao uso público, legalmente instituídas, com objetivos e limites definidos, sob condições especiais de administração e uso, as quais aplicam-se garantias de conservação, proteção ou utilização pública.

Art. $3^{\circ}$. As Unidades de Conservação se classificam em:

I - ÁREAS DE PROTEÇÃO AMBIENTAL (APA): são áreas de propriedade pública ou privada, sobre as quais se impõe restrições às atividades ou uso da terra, visando a proteção de corpos d'água, vegetação ou qualquer outro bem de valor ambiental definido pela Secretaria Municipal de Meio Ambiente - SMMA;

II - PARQUES DE CONSERVAÇÃO: são áreas de propriedade do Município destinadas à proteção dos recursos naturais existentes, que possuam uma área mínima de 10ha (dez hectares) e que se destinem à manutenção da qualidade de vida e proteção do interesse comum de todos os habitantes;

III - PARQUES LINEARES: são áreas de propriedade pública ou privada, ao longo dos corpos d'água, em toda a sua extensão ou não, que visam garantir a qualidade ambiental dos fundos de vale, podendo conter outras Unidades de Conservação dentro de sua área de abrangência;

IV - PARQUES DE LAZER: são áreas de propriedade do Município, que possuam uma área mínima de 10ha (dez hectares) e que se destinem ao lazer da população, comportando equipamentos para a recreação, e com características naturais de interesse à proteção;

V - RESERVAS BIOLÓGICAS: são áreas de propriedade pública ou privada, que possuam características representativas do ambiente natural do Município, com dimensão variável e que se destinem à preservação e à pesquisa científica;

VI - BOSQUES NATIVOS RELEVANTES: são os bosques de mata nativa representativos da flora do Município de Curitiba, em áreas de propriedade particular, que visem a preservação de águas existentes, do habitat da fauna, da estabilidade dos solos, da proteção paisagística e manutenção da distribuição equilibrada dos maciços vegetais, onde o Município 
impõe restrições à ocupação do solo;

VII - BOSQUES DE CONSERVAÇÃO: são áreas de propriedade do Município, destinadas à proteção dos recursos naturais existentes, que possuam área menor que 10ha (dez hectares), e que se destinem à manutenção da qualidade de vida e proteção do interesse comum de todos os habitantes;

VIII - BOSQUES DE LAZER: são áreas de propriedade do Município com área inferior a 10(dez hectares), destinadas à proteção de recursos naturais com predominância de uso público ou lazer;

IX - ESPECÍFICAS: são unidades de conservação criadas para fins e objetivos específicos, tais como: Jardim Botânico, Pomar Público, Jardim Zoológico e Nascentes.

$\S 1^{\circ}$. As Unidades de Conservação serão estabelecidas e terão suas características objetivos e peculiaridades definidas através de ato do Executivo Municipal.

$\S 2^{\circ}$. O enquadramento e a definição de Praças, Jardinetes, Jardins Ambientais, Largos, Eixos de Animação, Núcleos Ambientais, como Unidades de Conservação será objeto de regulamentação específica.

Art. $4^{\circ}$. Poderá o Poder Executivo, ampliar a área das Unidades de Conservação existentes, anexando propriedades inteiras ou frações, as quais pelas suas características físicas ou biológicas, venham a ampliar os benefícios já proporcionados pela Unidade de Conservação, através de compra, desapropriação, permuta por outro imóvel, transferência de potencial construtivo ou condições especiais de ocupação para a área remanescente, no caso de cessão de parte deste imóvel.

Parágrafo único. A transferência de potencial construtivo ou as condições especiais de ocupação dos imóveis remanescentes serão objeto de regulamentação específica.

Art. $5^{\circ}$. A implantação de novas Unidades de Conservação, seguirá a distribuição estratégica constante em mapa anexo parte integrante desta lei.

Art. 6º . Para ampliação do Sistema de Unidades de Conservação, poderá o Poder Público valer-se dos instrumentos estabelecidos no "caput" do art. $4^{\circ}$.

Art. $7^{\circ}$. A Secretaria Municipal de Meio Ambiente - SMMA desenvolverá Plano de Manejo específico para cada Unidade de Conservação existente ou para cada nova Unidade de Conservação que venha a ser criada.

Art. $8^{\circ}$. Esta lei será regulamentada, no prazo de 90 (noventa) dias contado a partir da data de sua publicação.

Art. $9^{\circ}$. Esta lei entrará em vigor 90 (noventa) dias após a data de sua publicação.

PALÁCIO 29 DE MARÇO, em 03 de janeiro de 2000.

CASSIO TANIGUCHI

PREFEITO MUNICIPAL 
ANEXO D - Vista parcial da localização do Bairro Cachoeira na cidade de Curitiba - PR, em destaque o Parque Municipal Nascentes do Belém.

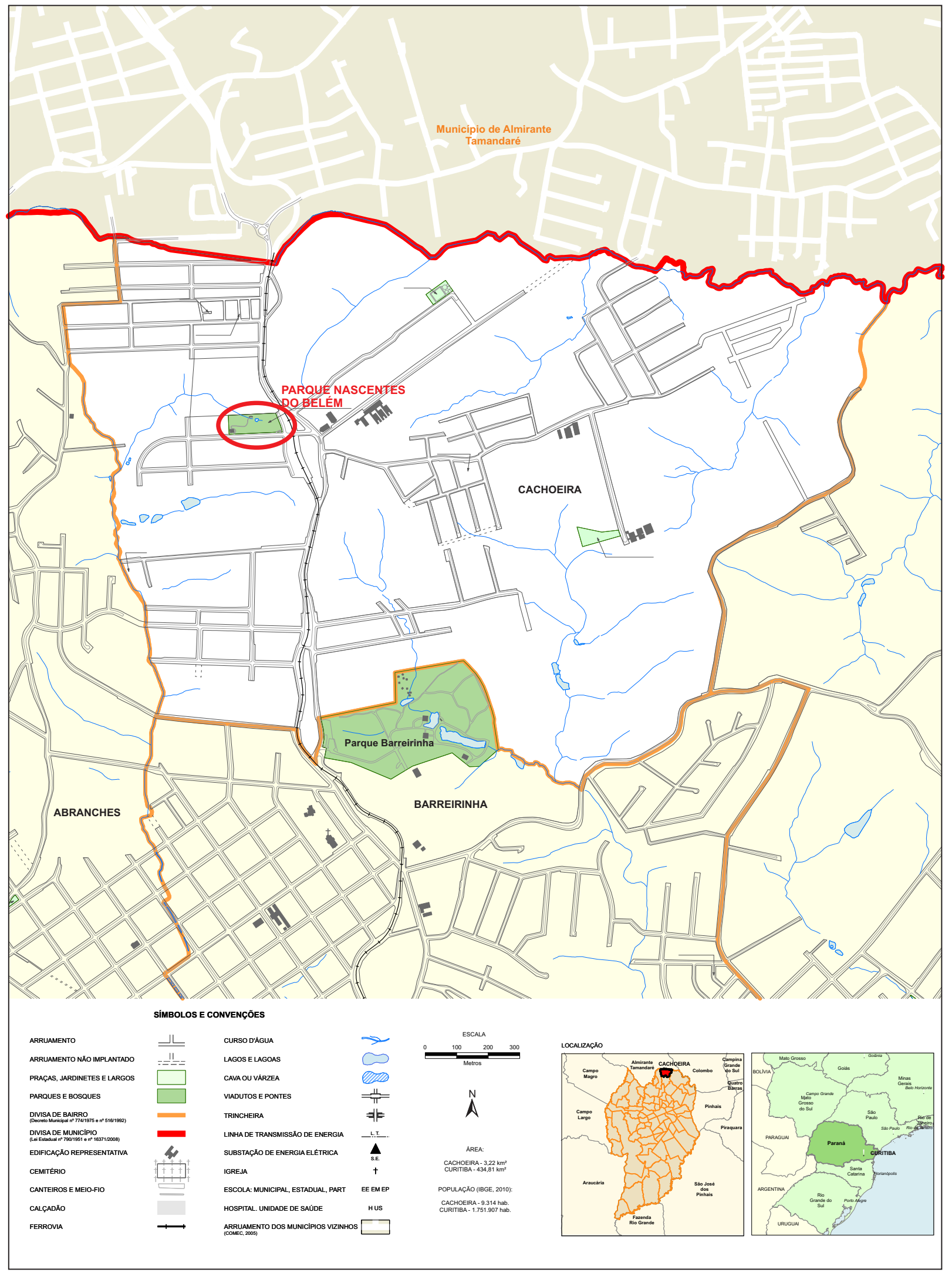

Fonte: Adaptado de IPPUC, 2013. 
ANEXO E - Vista parcial do Parque Municipal Linear Cajuru em relação ao Bairro Cajuru, Curitiba-PR

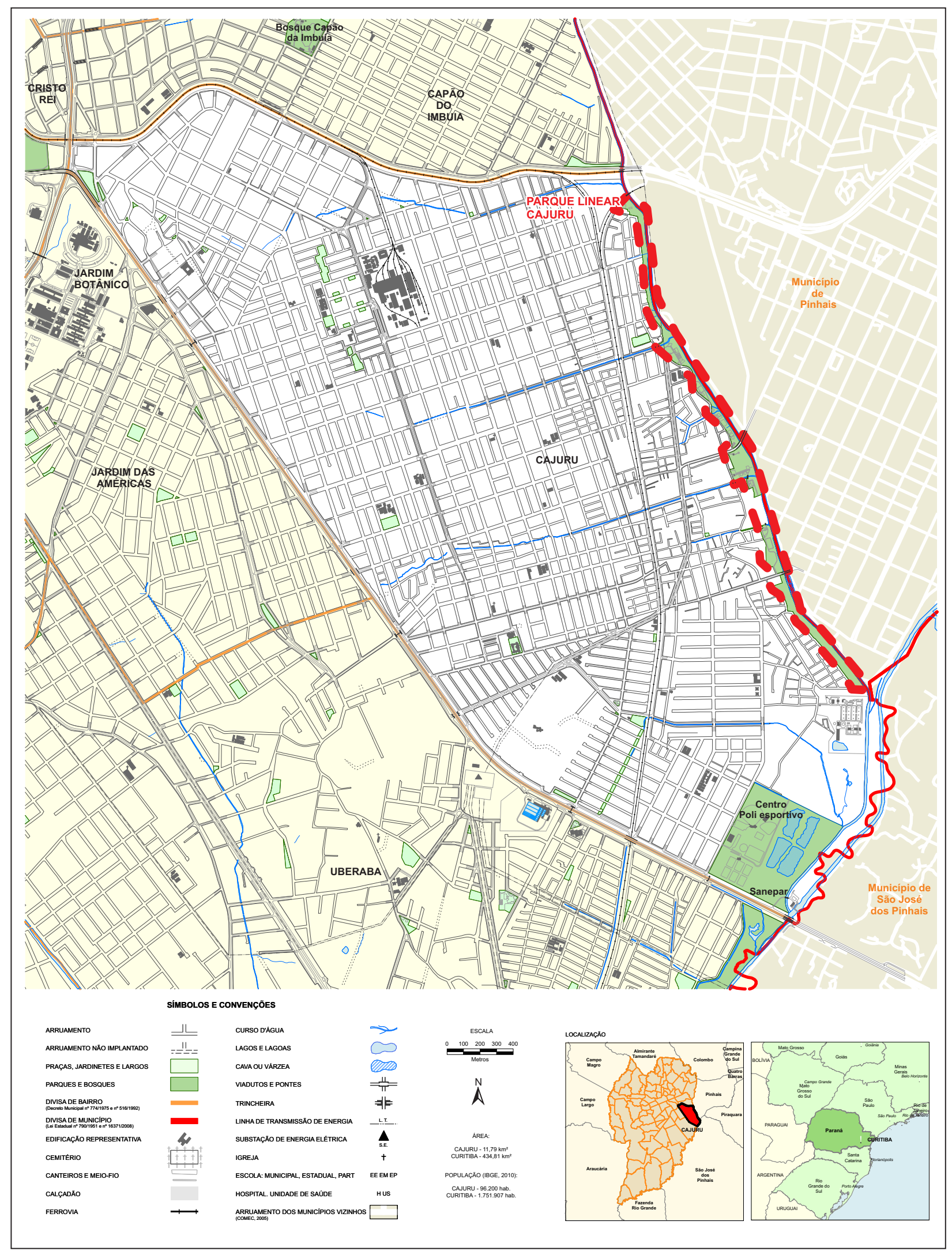

Fonte: Adaptado de IPPUC, 2013. 
ANEXO F - Vista parcial do Parque Municipal Passaúna em relação ao Bairro Augusta, Curitiba-PR

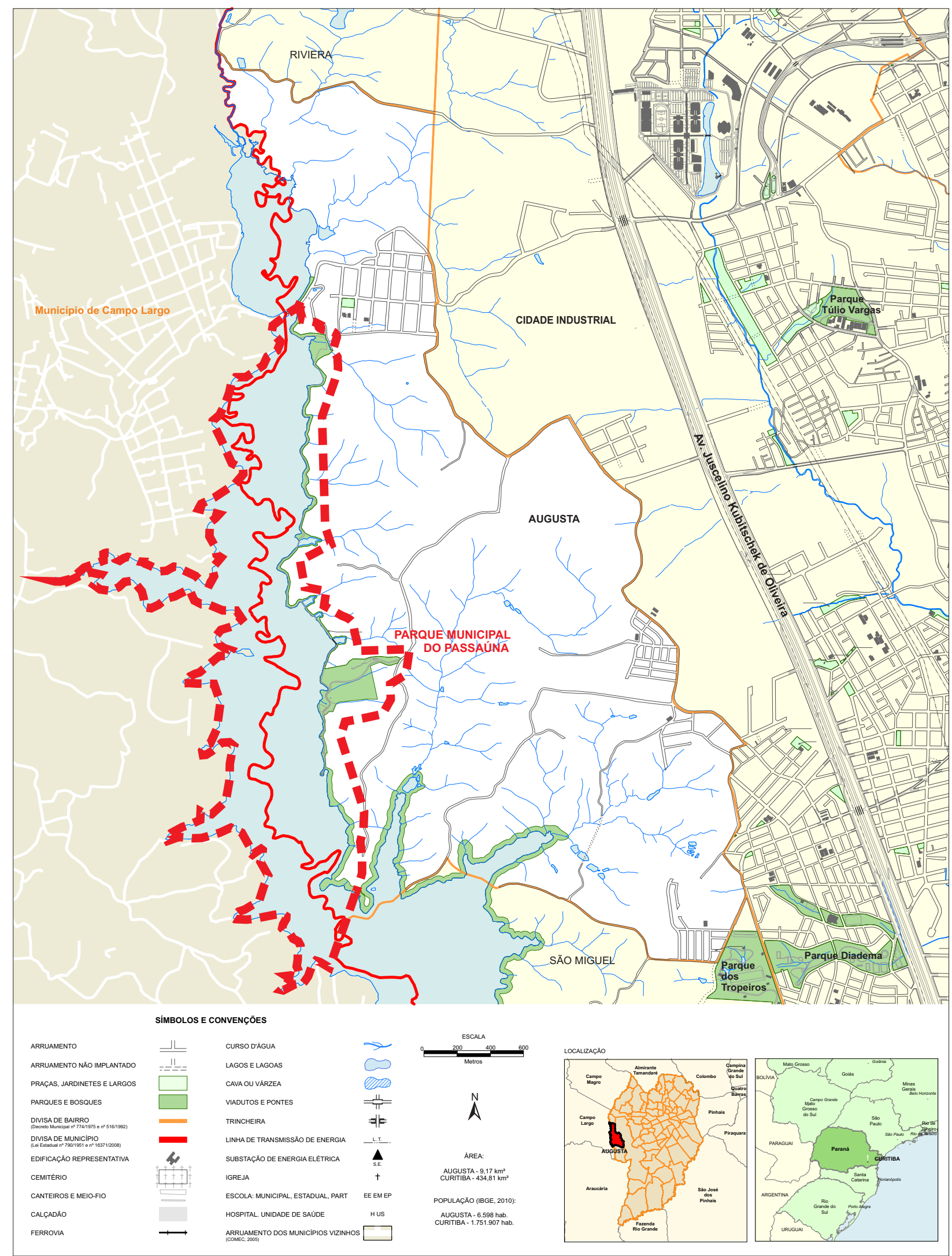

Fonte: Adaptado de IPPUC, 2013. 